\title{
THE CRAFT OF THE GOLDSMITH \\ IN WIELBARK CULTURE IN THE LIGHT OF THE FINDS FROM THE CEMETERY AT WEKLICE, ELBLACG COMMUNE AND OTHER NECROPOLIS OF ROMAN PERIOD FROM ELBLĄG HEIGHTS. TECHNOLOGICAL STUDIES OF SELECTED ASPECTS
}

\begin{abstract}
Natuniewicz-Sekuła M. 2017. The Craft of the Goldsmith in Wielbark Culture in the Light of the Finds from the Cemetery at Weklice, Elbląg Commune and Other Necropolis of Roman Period from Elbląg Heights. Technological Studies of Selected Aspects. Sprawozdania Archeologiczne 69, 185-233.

The paper presents selected aspects the goldsmithery of Wielbark culture in Roman period. Based on analyzes of chemical composition of finds from the cemetery at Weklice, site 7, Elbląg commune and finds from selected cemeteries of Roman period located on the Elbląg Heights, three main groups of raw materials were separated: gold, silver and copper alloys. They were also discussed selected techniques of production of jewelry and costume elements, most commonly used by Wielbark culture goldsmiths: casting, forging, filigree, granulation, gilding, soldering. Based on the collected data it was found that the Wielbark culture goldsmith workshop was one of the highest technology levels of ancient goldsmithery.
\end{abstract}

Keywords: Wielbark culture, Roman Period, goldsmithery, gold, silver and copper alloys, chemical composition analyzes

Received: 17.03.2016; Revised: 26.06.2017; Accepted: 01.07.2017

*Institute of Archaeology and Ethnology, Polish Academy of Sciences, Al. Solidarności 105, 00-140 Warsaw,

Poland; m_natuniewicz@yahoo.com 


\section{INTRODUCTION}

In Polish archaeological literature there is a shortage of writings on the specialized craftsmanship in the period of Roman influences which would take into account the rich portable source material from the Wielbark culture and, especially, one of the most popular crafts, namely goldworking. This is understood here as making ornaments and elements of dress out of colored metals, mainly alloys of copper and precious metals (gold and silver) and, to a lesser extent, from iron with gold and silver ornamentation.

The predominant number of finds made from non-ferrous metals have been discovered primarily in cemeteries, the fact that they had the appearance of being almost mass produced suggests that in the Wielbark culture there existed a highly specialized, organized and probably strictly controlled craft production intended for both the local and transregional markets. These are arguments evidencing the high level of intellectual and economic development of the local Wielbark culture communities.

Already in ancient times the goldsmith's craft was associated solely with the use of precious metals and surrounded by a special charm and mystery. The occupation of the goldsmith always held a high place in the hierarchy of artisans. In the ancient world a goldsmith determined the fineness of the gold and silver - he worked as needed, based on his own practice. However, it was often not so much the technology as dishonesty which led to debased gold content. With time, by the Late Middle Ages, European centres of goldworking imposed strict standards on their artisans, who had to use alloys of determined fineness which were stamped with town marks. But goldsmithery is only seemingly associated with the use of precious metals (primarily gold) as the basic raw material for making ornaments. In the Wielbark culture, the term should refer to finds made from alloys of copper and iron. Ornaments from other metals were made using the same goldsmithing techniques (primarily hammering). They were also ornamented with precious metals using goldsmith techniques - impressed foils, filigree and granulation. The Wielbark goldsmith's workshop produced both ornaments that played the double function of elements of dress and jewelry (e.g. brooches, bracelets, globular and pear-shaped pendants, biconical beads, s-shaped clasps, etc.) and other dress accessories such as buckles, belt-end fittings, belt mounts and the like. The Wielbark goldsmith was in fact a general smith capable of making various objects, both decorative and utilitarian, such as the iron tools needed for his work. The terms goldworking or goldsmithery are used in this article in a sense that is subjective because it is difficult to define precisely. They are in fact synonymous with the term metallurgy of non-ferrous metals and iron and not with the usual definition of a manufacturer working with precious metals. The basis for such an approach to the term goldsmithery and applying it to elements of bronze-working and smithery were, firstly, treatises and technological formulas, antique codices from the third century $\mathrm{AD}$. In the literature they are generally referred to as the "Theban Papyri" (in particular the Leyden papyrus X), known as such because of the material on which they were written and their place of origin (Upper 
Egypt). The papyri are a rich source of information concerning conservation and technology. The variety of technological matters dealt with in the text and the degree to which they coincide with issues concerning the Wielbark artefacts are surprising. This source is rarely made use of in archaeology of the Roman period (cf. Stawicki 1987). Another source taken into account here is the treatise of the medieval monk Theophilus Presbyter (Diversarum artium schedula - list of various arts), which includes an exhaustive account of the techniques and tools used in goldsmithing (see Kobielus 1998). The use of this latter source when discussing technology of production, despite the considerable time differences between the treatise and the artefacts analyzed here, seemed highly justified. Also helpful in building this definition was the saga of Wayland (Völund/Volundr, the mythical Scandinavian hero known to the Anglo-Saxons as Weland, later Wayland, Ger. Wiegand) a Germanic smith skilled in making items both of iron and precious metals, ornaments, as well as weapons (see Marold 2012, 234-240; Załuska-Strömberg 1986, 187-196).

The present study aims to provide the readers with a general outline of goldsmithery among Gothic culture communities, especially taking into account the material sources from the Wielbark culture.

In Polish literature on the subject, a comprehensive approach to "...describing the cognitive values of metal craftwork...” in the Wielbark culture is the work by Tadeusz Grabarczyk $(1983,5)$. Grabarczyk focused exclusively on a typological, classifying and chronological analysis, together with a description of the spread of the various categories of artefacts of non-ferrous metals, without drawing further conclusions concerning technological and sociological matters. Other Polish studies treat the topic in either piecemeal fashion or concentrate on individual issues, mainly dealing with production techniques, as does, for instance, Jarosław Strobin $(1995 ; 1998 ; 2000 ; 2007 ; 2015)$ in his immensely valuable works, or else highlighting specific decorative styles as the manifestation of a cultural attribute (Wołąiewicz 1974). These works, despite their enormous cognitive value, do not give a full picture of the development of the goldsmith's craft, treating it as being particularly associated with the local social elites.

Below I discuss primarily the technological aspects, mainly with reference to macroscopic (comparison of fabricating techniques) and physicochemical (determination of the chemical composition) analysis of objects made of copper, silver and gold alloys, from selected cemeteries of the Wielbark culture on the Elbląg Heights. The rationale for the choice of the Wielbark settlement complex on the Elblagg Heights is the fact that this area has long been noted as being, from about the middle of the first to the beginnings of the fourth century $\mathrm{AD}$, one of the most important cultural centers of the peoples living in the Baltic zone, located at the junction of intersecting trade routes (see Natuniewicz-Sekuła and Okulicz-Kozaryn 2007, fig. 2; 2008; fig. 2; Okulicz-Kozaryn 1992a, 1992b). This is indicated by the density of cemeteries from the Roman period and the considerable richness of the grave furnishings. Most of the archaeological research in this area was conducted before World War II, and most of the finds disappeared during the turmoil of war. For this 
reason, the research being done by the author at one of the largest cemeteries of the Wielbark culture at Weklice, site 7, Elbląg Comm., is of particular cognitive value.

The cemetery at Weklice has a unique place in the archeology of the Central European Barbaricum because, apart from the typical Wielbark culture artefacts, excavations revealed numerous Roman imports and Scandinavian style ornaments, as well as specific features of burial with analogies in Scandinavia. The site is one of more than twenty registered points of dense settlement of Wielbark culture, stretching in an arc along the coast of the Vistula Lagoon and today's Lake Drużno depression, between the estuary of the river Pasłęka and the Dzierzgoń river (cf. Natuniewicz-Sekuła and Okulicz-Kozaryn 2007, fig. 2). It is also known that the landscape of the area in the first centuries AD differed greatly from today's, because of huge changes in the hydrographic network of the depression of Żuławy valley. Today Drużno is a declining lake but at that time it was a vast bay of the Vistula Lagoon, reaching over $40 \mathrm{~km}$ south along the foot of the Elbląg Heights (cf. Kasprzycka 1999). Such a configuration of waters and coast lines created a favorable situation for the shipping lanes crossing here. Land routes leading to the nearby amber rich Sambia Peninsula, to the south and west, also began here - following the famous wooden roads in the valley of the river Dzierzgon. This situation, when the geopolitical conditions were favorable, made it possible for the population inhabiting the Elbląg Heights to maintain lively shipping contacts on the Baltic Sea and control the crisscrossing overland routes along which long-distance trade was carried out and groups of people travelled from the North to the Black Sea (see Natuniewicz -Sekula and Okulicz-Kozaryn 2011). As a result, the material from the Weklice necropolis constitutes the base source for this work.

\section{CHEMICAL COMPOSITION OF ANALYZED FINDS AND THEIR INTERPRETATION}

Chemical analysis was carried out primarily on artefacts made from alloys of precious metals and copper alloys found at the Weklice site, as well as a small number of objects discovered before World War II at cemeteries on the Elbląg Heights, which are at presently kept at the Archaeological and Historical Museum in Elbląg (see Natuniewicz 2000). Moreover, a pair of rosette brooches (Rossetenfibeln) from grave 10 in the Oksywie and Wielbark cemetery at Lubieszewo, Nowy Dwór Gdański Comm. (cf. M. Jonakowski 2001), also in the collection of the Elbląg museum. The main features of Wielbark goldsmithing described below are supported by the experimental recreation of ornaments using past techniques. In addition, the analyses have been supplemented by a comparative study of Wielbark culture materials from sites in Pomerania and northern Greater Poland. Moreover, when discussing the background of goldsmithery, not only finds from Barbaricum but also from the Roman provinces have been included.

For the purpose of determining the raw material groups of metal alloys used in the Wielbark culture, the chemical composition of 147 artefacts, local and imported from 
the Roman Empire, was analyzed using an X-ray fluorescence spectrometer. The tests were carried out at the Bio- and Archaeometric Laboratory of the Polish Academy of Sciences in Warsaw. A total of 233 analyses were carried out, with one object often undergoing several measurements due to its composition and production technique combining several groups of raw materials. The selection of artefacts chosen for analysis was made on the basis of the raw material used. The objects were grouped according to function, distinguishing ornaments and elements of dress, and chronologically, in order to determine possible changes in the use of a given alloy in the production of concrete forms during all the phases of the Weklice cemetery (for more on the chronology of the cemetery see: Natuniewicz-Sekuła and Okulicz-Kozaryn 2011, 125-133). As a result of these analyses, the tested items could be divided into three groups of raw materials: alloys of gold, silver, and copper, which were compared with other metallographic analyses performed for artefacts from the Roman period. Finds decorated with tin coatings were described separately in the third group - copper alloys.

\section{GOLD, ITS ALLOYS, AND GOLD AND SILVER GILDED FOILS, AND ELECTRUM}

Gold (chemical symbol Au) is a precious metal, very soft and the most ductile of all metals, but relatively rare in nature in a "pure" form, as it is almost always contaminated in some way by different elements. Fineness is the expression used to denote the content of the metallic element in the alloy, expressed in parts per thousand. For example, if the alloy contains $90 \%$, of a given element then the fineness is 900. In the case of gold, a fineness of 1000 (otherwise known as 24-carat gold), only functions by definition, because, in fact, in the laboratory only a fineness of 999 or 999.9. can be obtained. Thus, gold with a fineness of 1000 does not really exist, either in nature or in gold articles. In goldsmithing "pure" gold is too soft to be worked and it is therefore hardened by mixing, by means of heat treatment, usually with silver and copper. The gold content in the alloy must be not less than $10 \%$. Today, other alloy components are used: nickel, platinum, palladium, manganese and zinc, and, less often, cadmium, cobalt and beryllium (Knobloch 1977, 88-89).

For the purpose of this work, the chemical composition of 24 items (Fig. 1: 1-6; Table 1 - CD) was analyzed; some of the analyzed artefacts were solid gold, others decorated with gold or silver gilded foils. Analyses show (cf. Table 1) that most of the solid gold artefacts, i.e. s-shaped clasps, biconical beads and globular pendants (Fig. 1: 1-5) were made of gold of a high (from c. 900-980) fineness. In this group of artefacts the globular pendant from grave 45 at Weklice (Fig. 1: 6) is characterized by a lower gold content (c. 700-750), as is the partly melted globular pendant discovered at Nadkole, site 2, Węgrów Comm. (Andrzejowski 1998, 130). The group of finds from the barrow cemetery of the Wielbark culture at Leśno, Chojnice Comm., investigated by spectral analysis, also had a lower gold content (c. 790-890). Among them were an s-shaped clasp and pear-shaped pendant from 
the princely grave no. I and two gold rings from princely grave no. IV. However, the results of these analyses and, above all, their lack of interpretation and discussion of the method, in my opinion, raise many reservations (cf. Walenta 2009, 12-13, 19, 214-215, pl. XCIX: 5-6; CIII:3).

The differences in the gold content of the alloys used are due to the heterogeneity of the alloy and the location of the sample. The results of the analyses show that silver and copper are the most common added elements in these alloys, respectively in proportions of up to a maximum of $2 \%$ ), with small parts of sulfur, chromium, manganese, iron, nickel and zinc. Except for the sulfur and iron that are present here but do not always occur in gold alloys and may be the result of contamination of the analyzed objects due to deposition under different soil conditions, the other elements are usually constituents of native gold ores. It should be assumed that, as is the case today, the addition of silver and copper was intentional in order to improve the technological properties of the alloy.

There is also a very interesting instance of the use of electrum for two of the pendants, a globular and a pear-shaped one (cf. Fig. 1: 7-8). Electrum is a natural alloy of gold and silver in similar proportions, with a characteristic light yellow silvery, pale hue. In Polish literature on the subject, this alloy is often incorrectly referred to as "elektron" (cf. Madyda-Legutko et al. 2010, 390-391). Wherein the proper "electron" has two basic definitions: 1. The electron is an elementary particle composition of the atom (proton or neutron); 2 . The electron is a magnesium alloy of aluminum and zinc with a low specific weight and high strength mainly used in aircraft construction (cf. Czerni 1967, 110). While electrum (for etymology cf. Stawicki $1987,36,60$, footnote 165 ) is a native element mineral, a natural alloy of silver and gold in almost identical proportions, of a pale yellow color. The lowest admissible gold content in electrum is 20\% (Lippmann 1919, 533; Neuburger 1919, 13). It is worth noting that as early as Pliny in his Natural History, called gold rich in silver electrum. From this source it is also known that in Roman times this alloy was artificially produced: "An artificial electrum, too, is made, by mixing silver with gold" (Pliny XXXIII, 23 - translated by Bostock, Riley 1857, 105).

In antiquity, in Greece, Egypt and the ancient cultures of the Middle East, electrum was a very popular material for making ornaments, and studies indicate that it was also used as a solder for joining elements made from gold of a high fineness (Maryon 1971, 8; Wolters 1975, 32).

Finds made from electrum in the Roman period from the territory of Poland are extremely rare. Globular pendants made of such an alloy were discovered i.a. at the cemetery at Modła, Mława Comm., grave 96 (Grzymkowski 1986, 249, fig. 18: d); and at Orońsko, Szydłowiec Comm. (Kokowski 1991, 117; cf. also Madyda-Legutko et al. 2010 390-391). Based on the analysis of metallographic results, it can be presumed that such an alloy was used to make a Roman amethyst ring from a settlement at Leśno, Chojnice Comm. (gold $\geq$ 64.50\%, silver $23.09 \%$ with other trace elements) and a pear-shaped pendant from grave 33 from the cemetery at Leśno, Chojnice Comm. (gold $\geq 50.22 \%$, silver 35.26\%, with other 

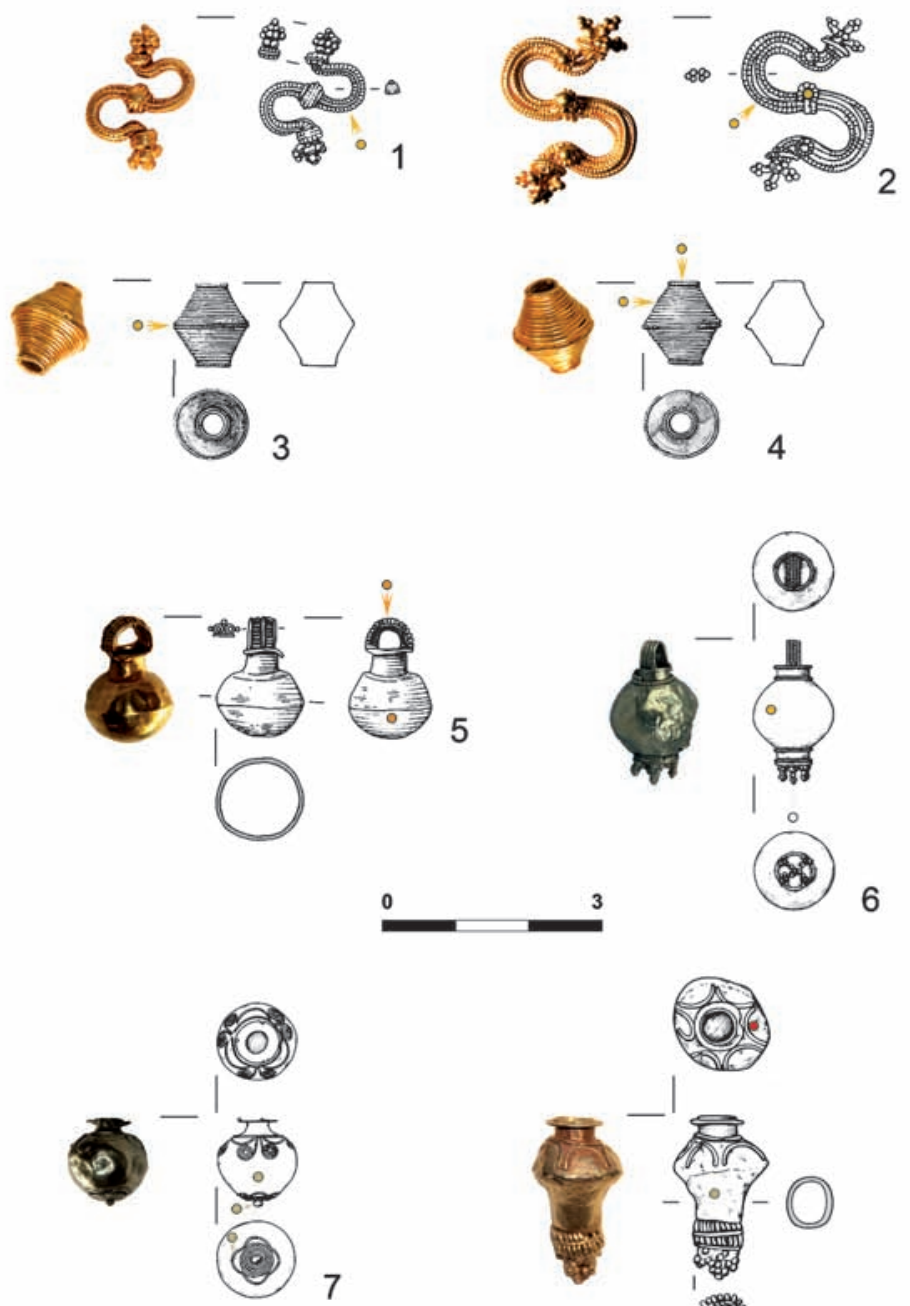

8

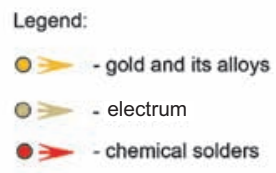

The symbols indicate part of finds to be analysed by the chemical composition

Fig. 1. Gold and its alloy and electrum - selection of analyzed local finds: 1 - S-shape clasp (stray find, Weklice, site 7) filigree, granulation; 2 - S-shape clasp (grave 208, Weklice, site 7) filigree, granulation; 3-4 - biconical beads (grave 208, Weklice, site 7) filigree; 5 - globular pendant (grave 360, Weklice, site 7) filigree; 6 - globular pendant (grave 45, Weklice, site 7) filigree, granulation; 7 - globular pendant (grave 26B, Weklice, site 7) filigree, granulation; 8 - pear shape pendant (grave 544, Weklice, site 7) filigree, granulation (photo M. Natuniewicz-Sekuła, drawing by E. Pazyna, M. Natuniewicz-Sekuła) 


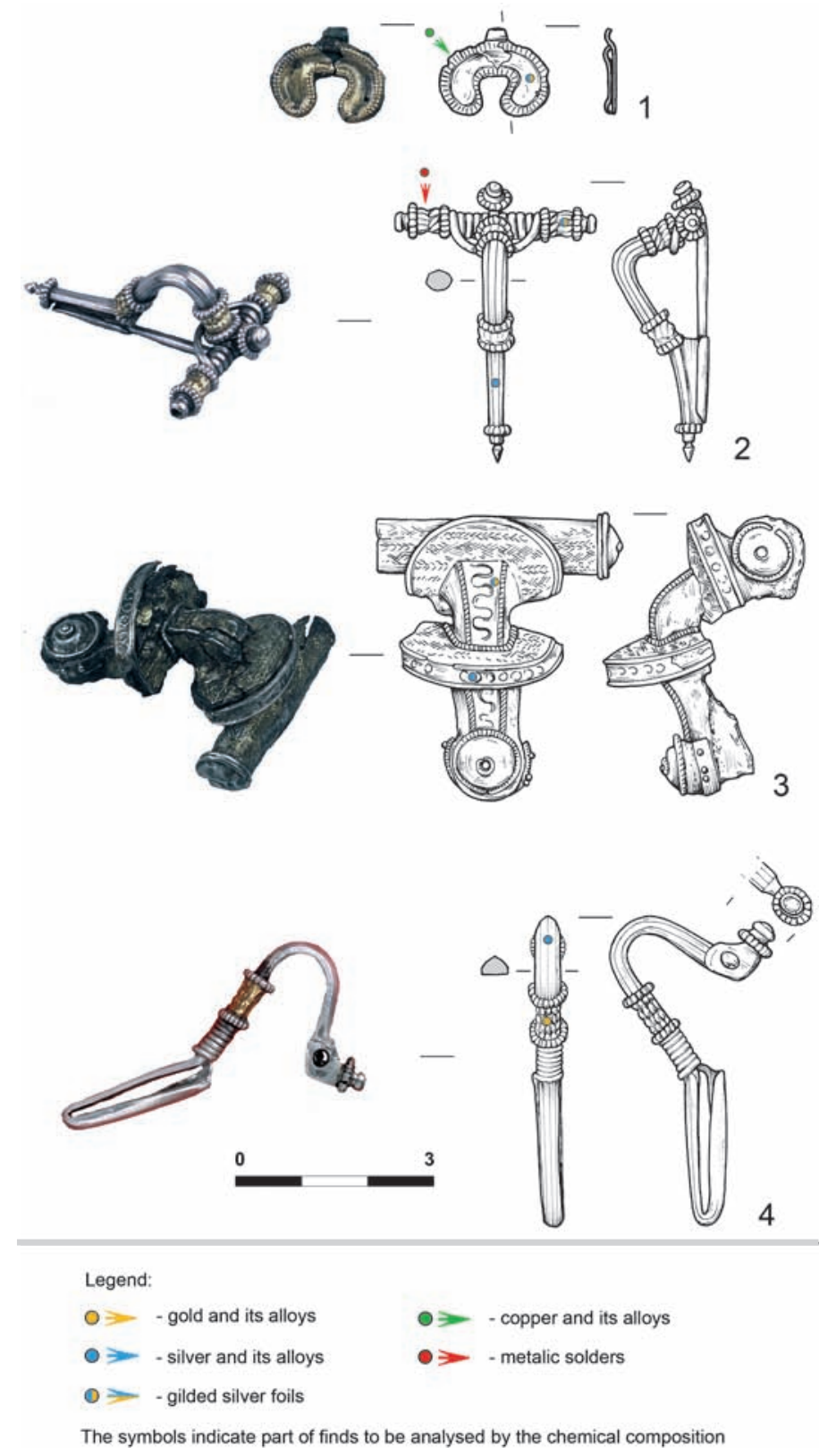

Fig. 2. Gold and gilded silver foils - selection of analyzed local finds: 1 - lunula pendant (grave 275, Weklice, site 7) brass, silver gilded foil; 2 - brooch (grave 275, Weklice, site 7) silver, silver gilded foil, traces of metallic solder; 3 - brooch (grave 26B, Weklice, site 7) iron alloy, silver and silver gilded foil, filigree, granulation; 4 - brooch (stray find, Weklice, site 7) silver, gold foil, filigree (photo M. Natuniewicz-Sekuła, drawing by E. Pazyna, M. Natuniewicz-Sekuła) 

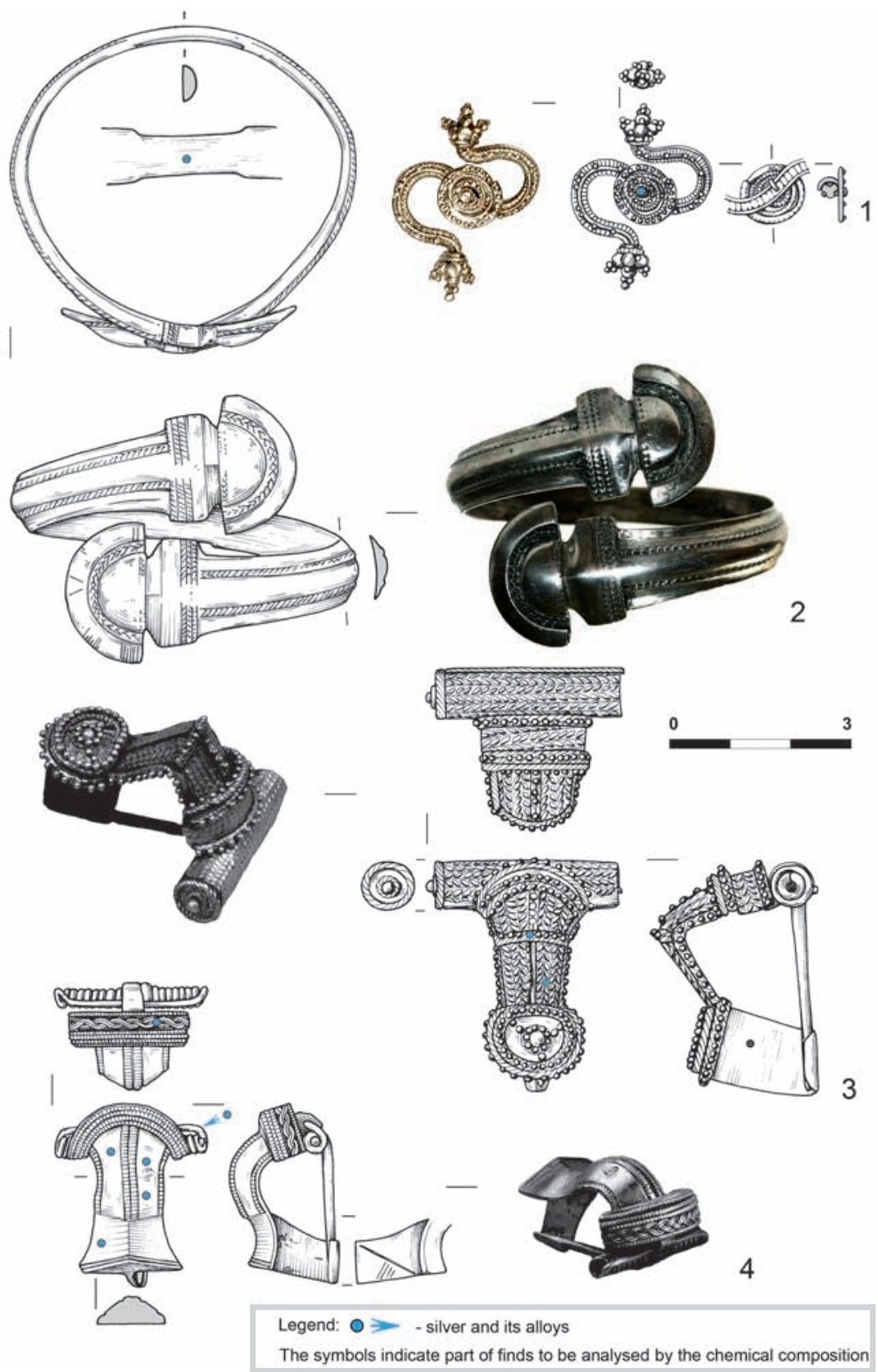

Fig. 3. Silver and its alloy, silver foils - selection of analyzed local finds: 1 - S- shape clasp (grave 524, Weklice, site 7) filigree, granulation; 2 - Schlangenkopf bracelet (grave 26B, Weklice, site 7) forging; 3 - brooch (grave 252, Weklice, site 7) brass, silver foil, filigree, granulation; 4 - brooch (grave 432, Weklice, site 7) filigree (photo M. Natuniewicz-Sekuła, drawing by E. Pazyna, M. Natuniewicz-Sekuła) 

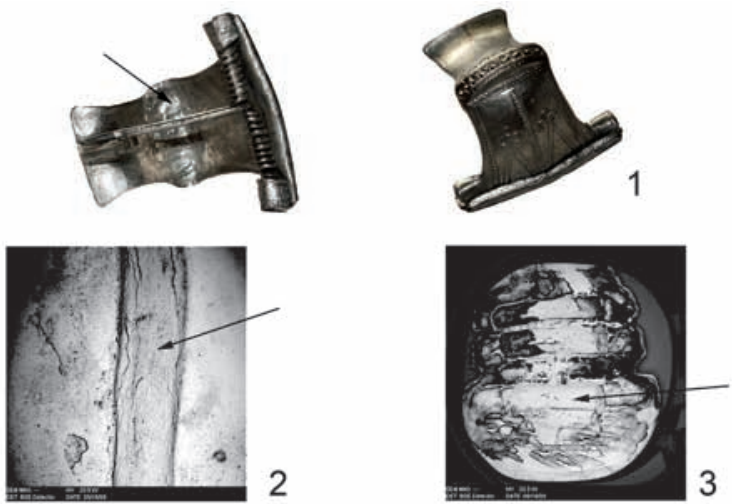

0

ca 3
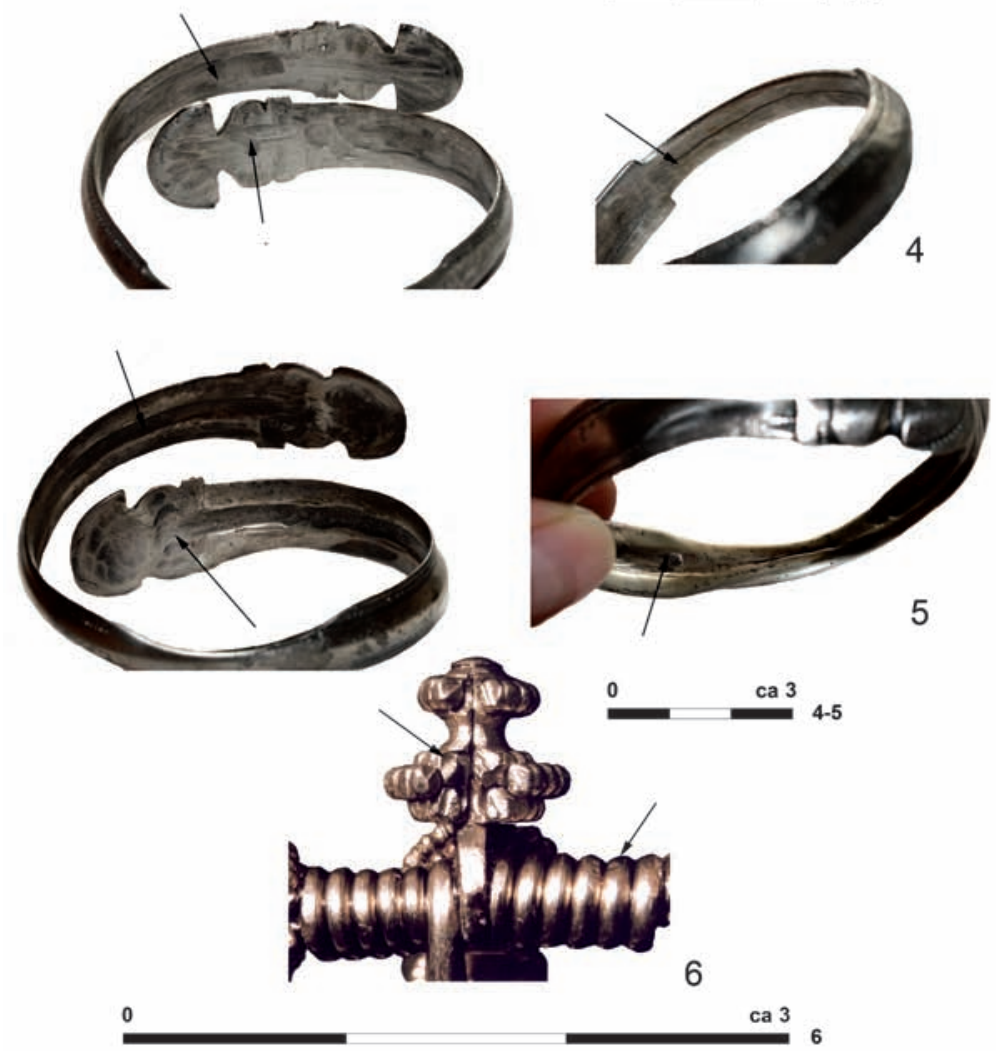

Fig. 4. Weklice, site 7, Elbląg Comm. Selection of local silver finds finished by forging and modeling in dies (traces of forging marked by arrow): 1 - brooch (grave 342); 2 - Schlangenkopf bracelet, bow fragment (stray find); 3 - head of Schlangenkopf bracelet (stray find); 4-5 - Schlangenkopf bracelets (grave 208); 6 - upper part of brooch (grave 275) detail of forged knob and forged in die spring. In addition, visible traces cut off filigree wire (photo M. Natuniewicz-Sekuła) 


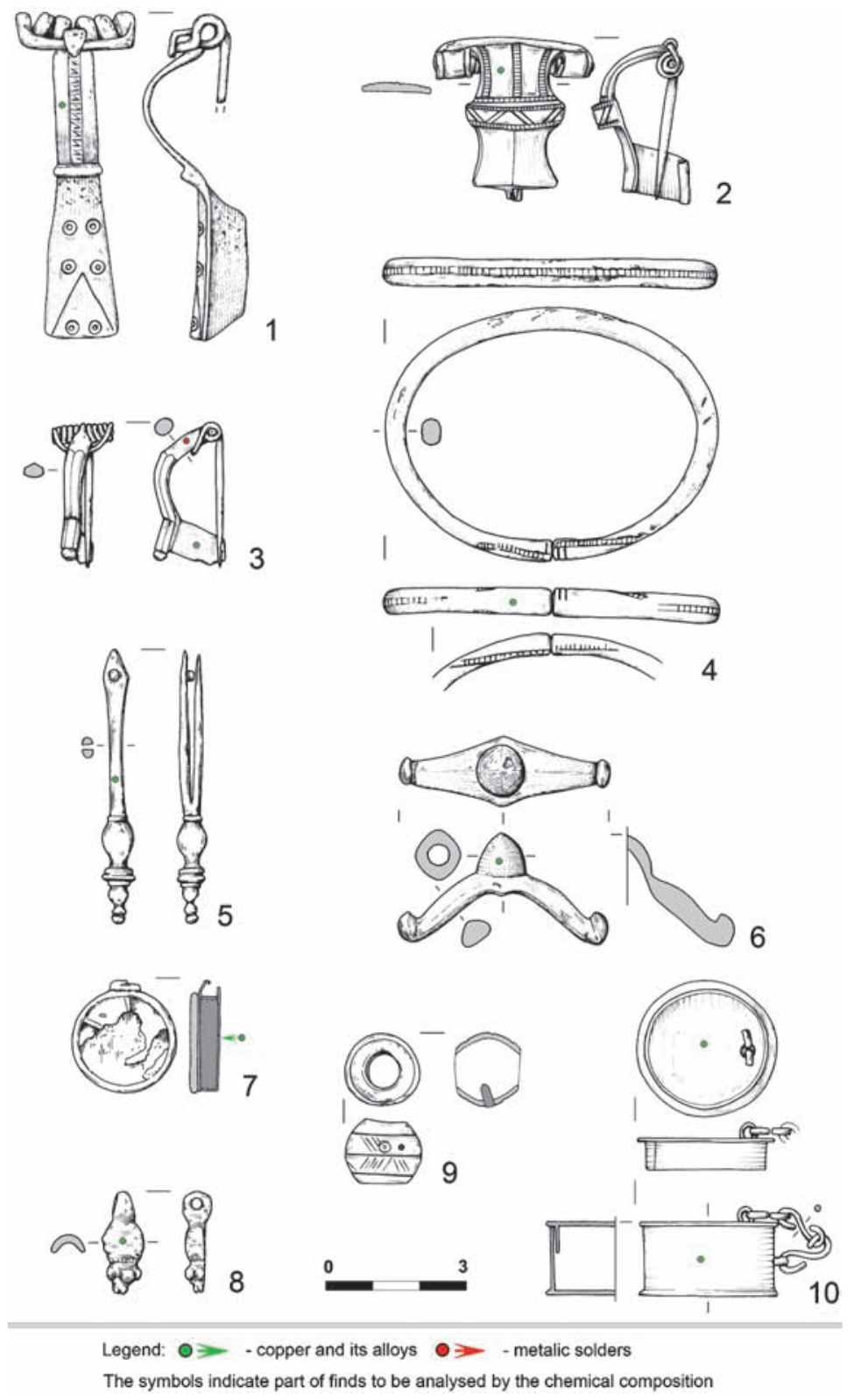

Fig. 5. Copper and its alloys: selection of analyzed local finds: 1 - brooch (Rubno Wielkie, Elbląg Comm. without grave number) brass; 2 - brooch (grave 495, Weklice, site 7) brass; 3 - $\mathrm{f}$ brooch (grave 24, Weklice, site 7) brass; 4 - bracelet (grave 492, Weklice, site 7) brass; 5 - strap end (grave 14, Weklice, site 7) brass; 6 - spur (grave 521, Weklice, site 7) brass; 7 - capsule pendant (grave 278, Weklice, site 7) brass; 8 - pear shape pendant (grave 519, Weklice, site 7) brass; 9 - bead (grave 150, Weklice, site 7) brass; 10 - cylindrical box (grave 174, Weklice, site 7) brass (drawing by E. Pazyna, M. Natuniewicz-Sekuła) 

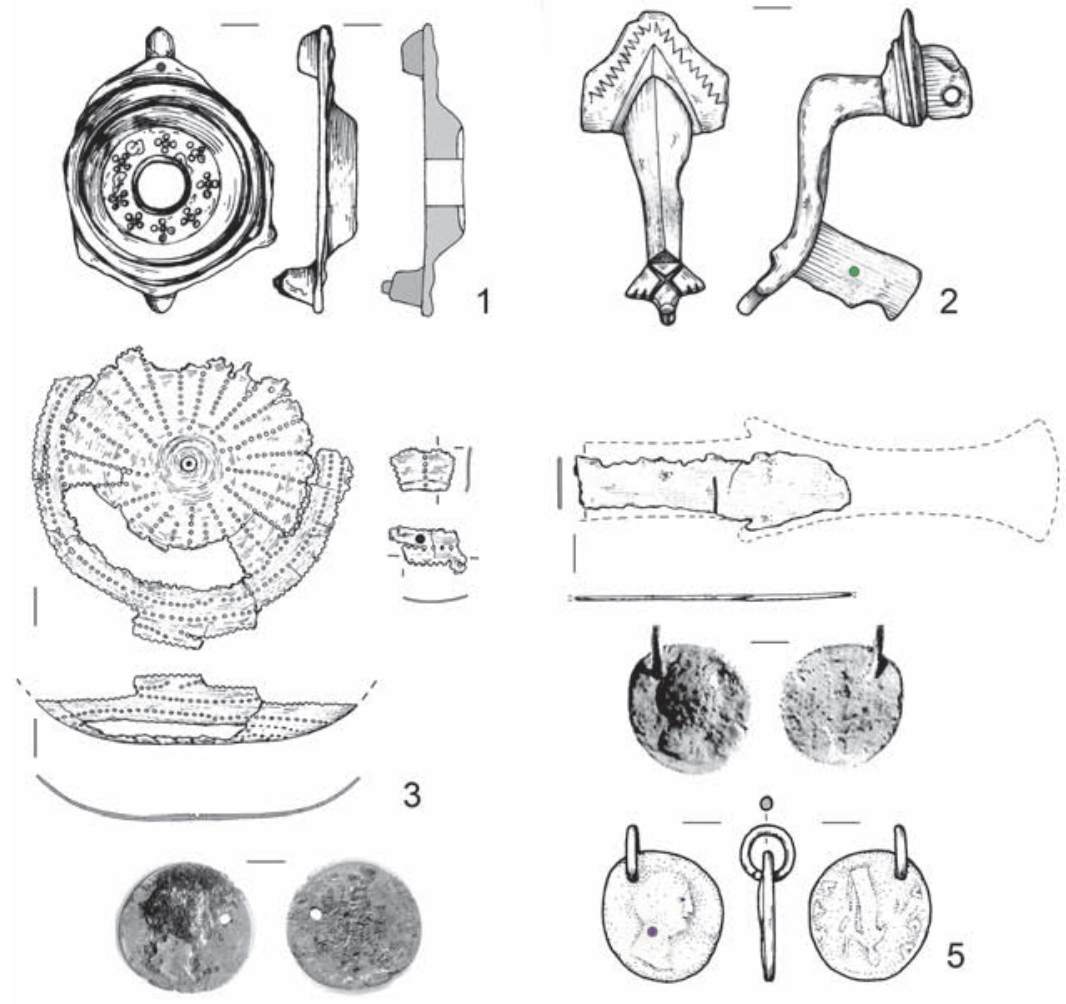

3
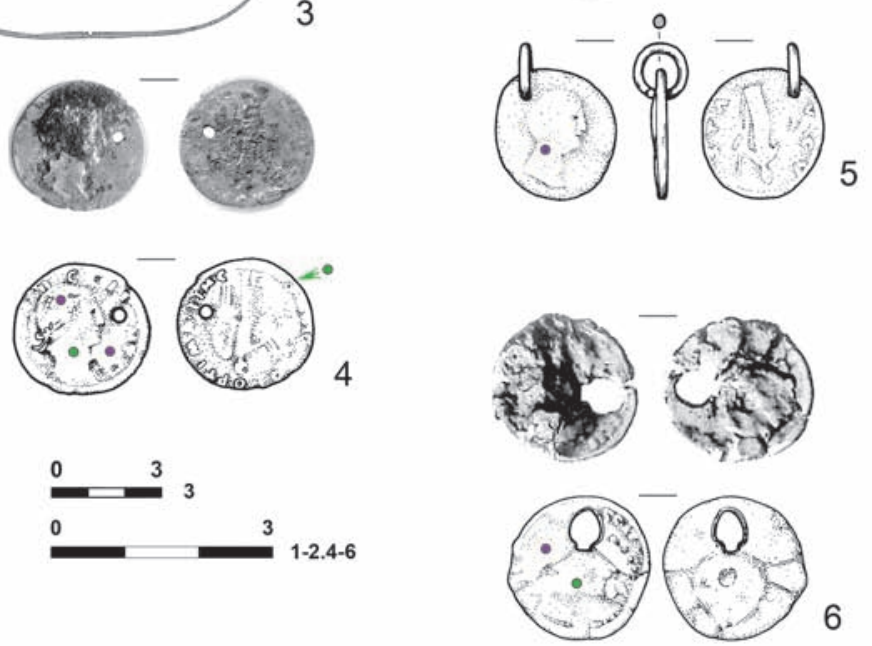

Legend: $0 \geqslant-$ - copper and its alloys $0 \geqslant-$ tin coatings

The symbols indicate part of finds to be analysed by the chemical composition

Fig. 6. Copper and its alloys: selection of analyzed imported from Roman Empire finds: 1 - brooch (grave 184, Weklice, site 7) tin-lead bronze, enamel; 2 - brooch (stray find, Weklice, site 7) tin-lead bronze; 3 - strainer in fragments (stray find, Weklice, site 7) tin bronze; 4 - coin denarius subaeratus (grave 379, Weklice, site 7) tin-lead bronze, tin coating; 5-6 - coins denarii suaberatii (grave 141, Weklice, site 7) tin-lead bronze, tin coating (drawing by E. Pazyna, M. Natuniewicz-Sekuła) 

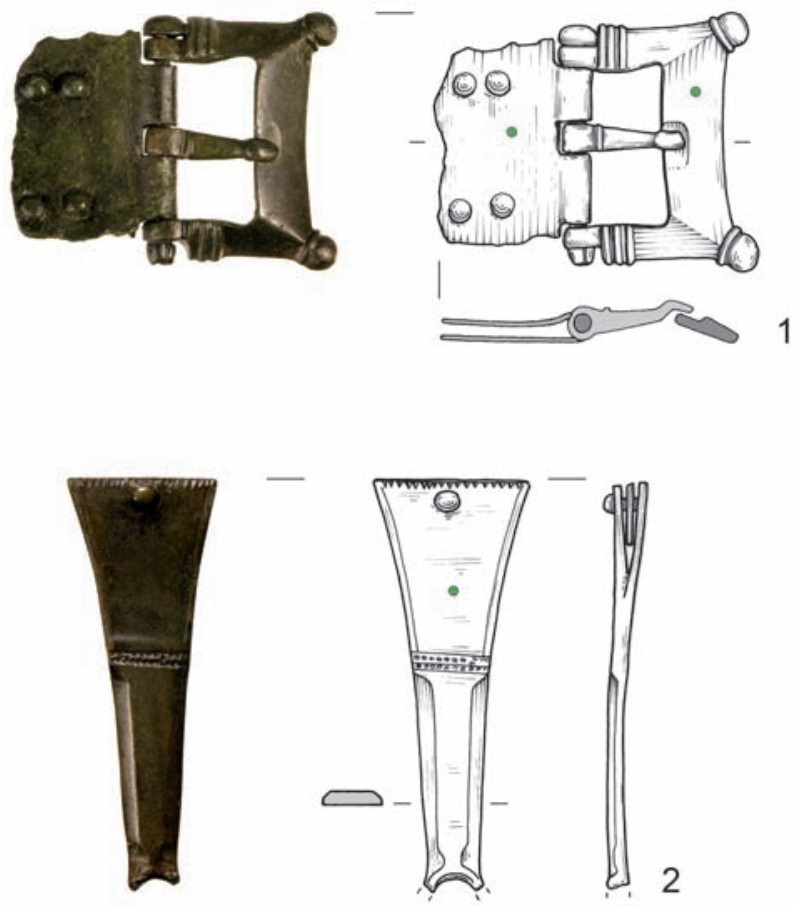

0 3

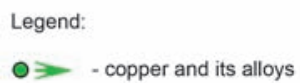

The symbols indicate part of finds to be analysed by the chemical composition

Fig. 7. Weklice, site 7, Elbląg Comm. Grave 208, imported belt fittings: 1 - buckle frame, tin-lead bronze, buckle plate, brass; 2 - belt end fitting, tin-lead bronze (photo M. Natuniewicz-Sekuła, drawing by E. Pazyna, M. Natuniewicz-Sekuła) 

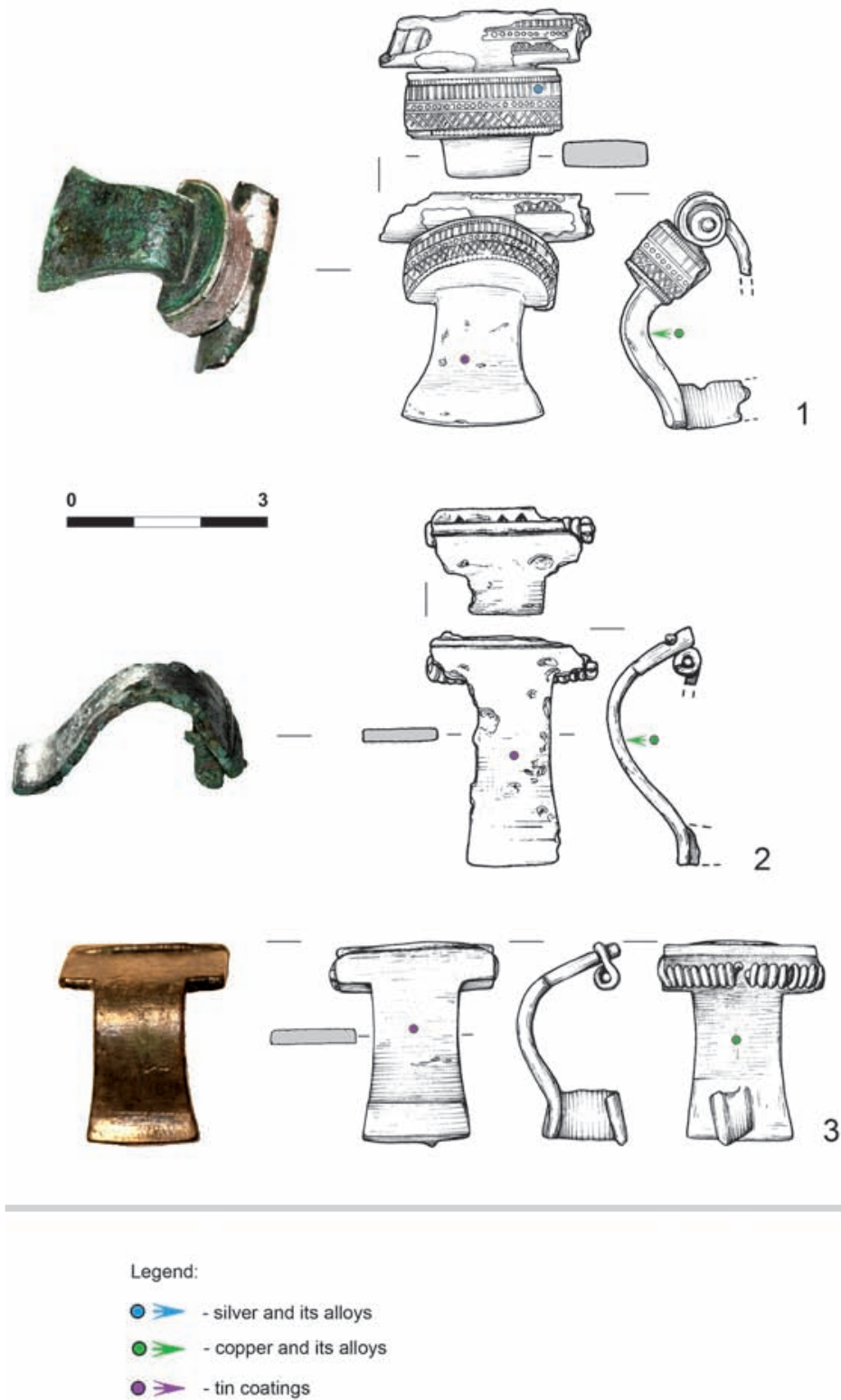

The symbols indicate part of finds to be analysed by the chemical composition

Fig. 8. Weklice, site 7, Elbląg Comm. Selection of finds with tin coatings: 1 - brooch (grave 386) brass, silver impressed foil, tin coating; 2 - brooch (grave 386) brass, tin coating; 3 - brooch (stray find) brass, tin coating (drawing by E. Pazyna, M. Natuniewicz-Sekuła) 


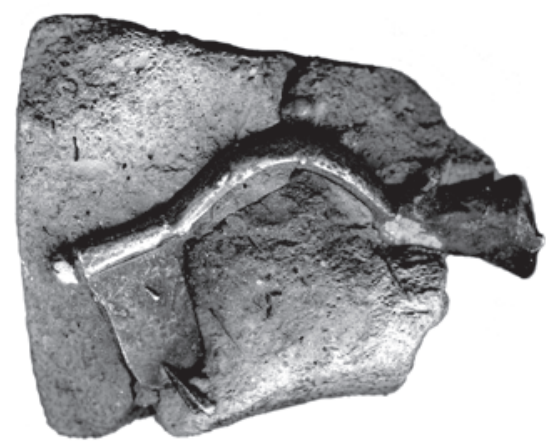

0

3

Fig. 9. Reconstruction of casting clay mold with silver half-product of brooch bow A. VII, 1 (according to M. Sekuła, photo M. Natuniewicz-Sekuła)

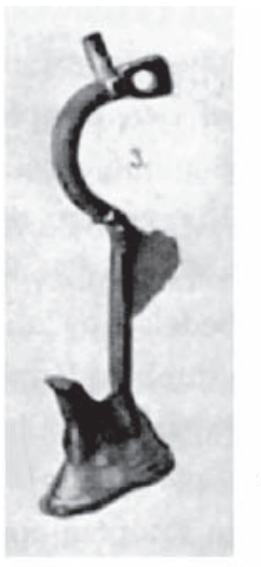

1
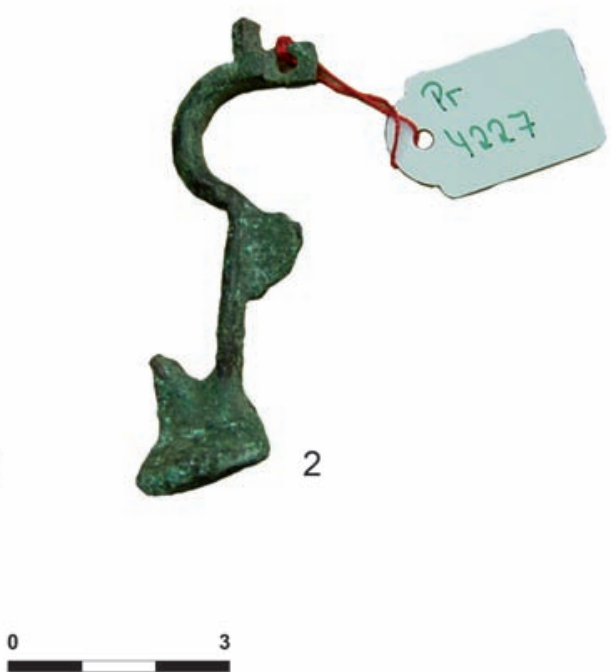

Fig. 10. Frombork, Braniewo Comm., part of "caster" hoard. Fragment of cast the copper alloy brooch foot attached to the next half-product of an identical brooch: 1 - (according to F. E. Peiser, H. Kemke 1914); 2 - original from the collection of former Prussia-Museum (photo M. Natuniewicz-Sekuła) 

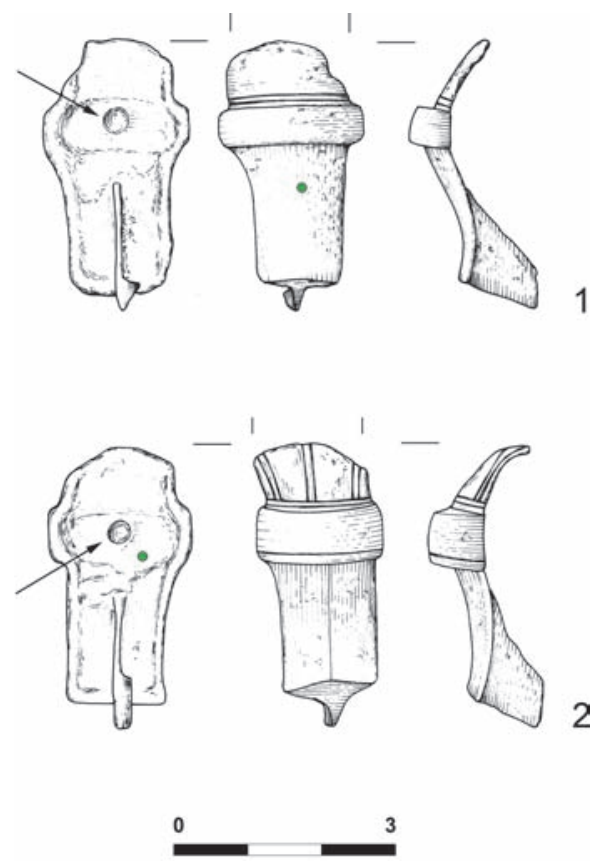

Fig. 11. Traces of the intermediate tool (marked by arrows), which bows of brooches were forged in the die: 1-2 brass brooches (Elbląg. Pole Nowomiejskie or Moniuszki street - mixed finds) (drawing by E. Pazyna, M. Natuniewicz-Sekuła)
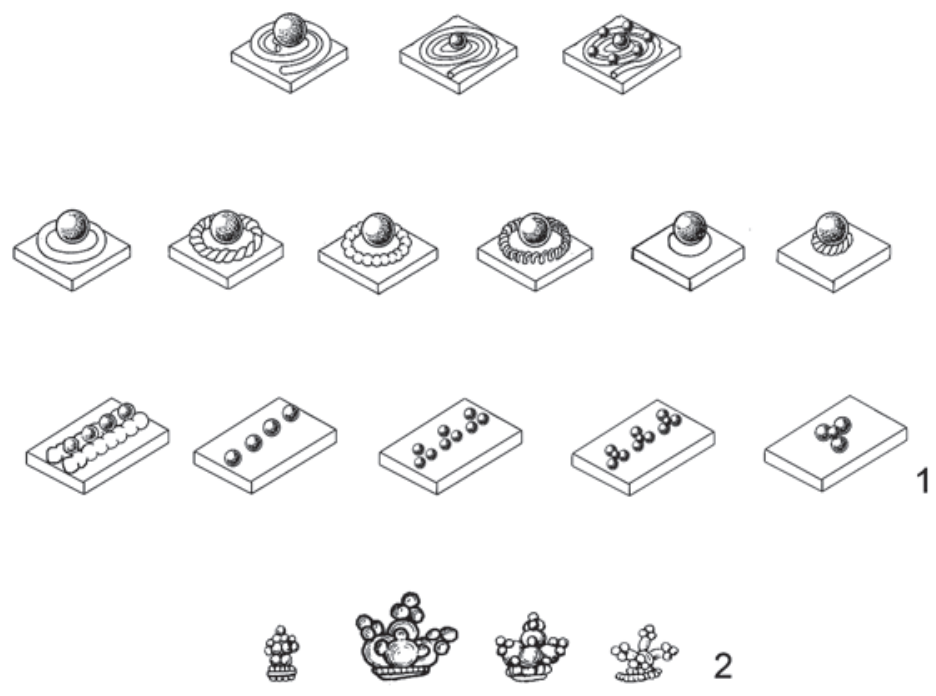

Fig. 12. An examples used in the analyzed find from Weklice composition of granulation: 1 - schemes according to Wolters (1983); 2 - modfication by the author 

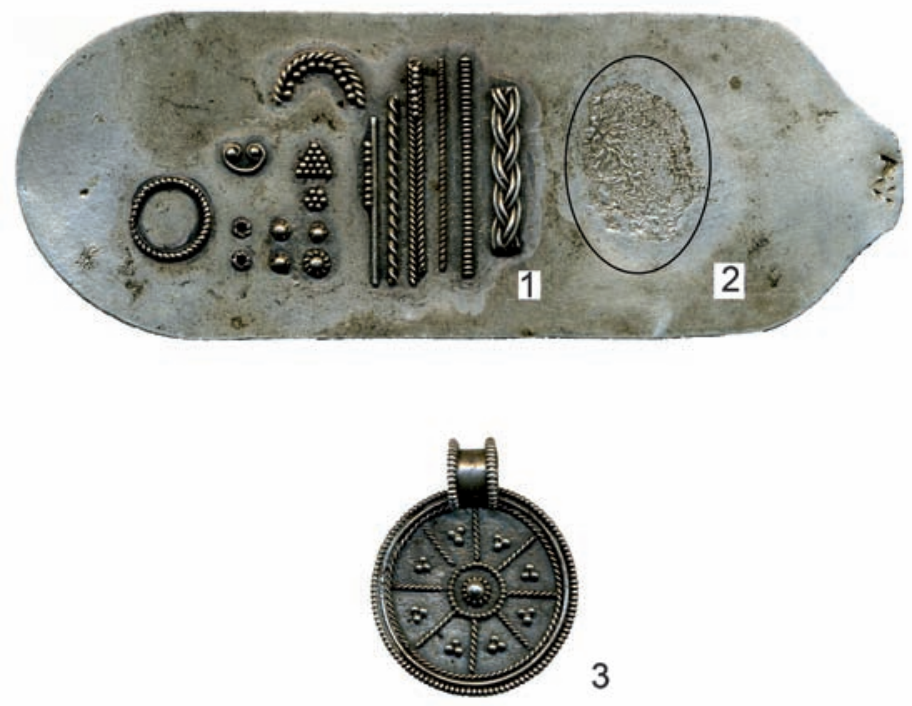

0

3

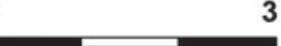

Fig. 13. An examples of soldering filigree and granulation with chemical solder: 1 - decorative elements of filigree and granulation occurring on the analyzed finds; 2 - the porous surface of the silver plaque as the result of a shallow diffusion chemical solder based on copper compounds; 3 - an example experimentally made a silver pendant in filigree and granulation technique soldered with chemical solder (according to M. Sekuła, photo M. Natuniewicz-Sekuła) 

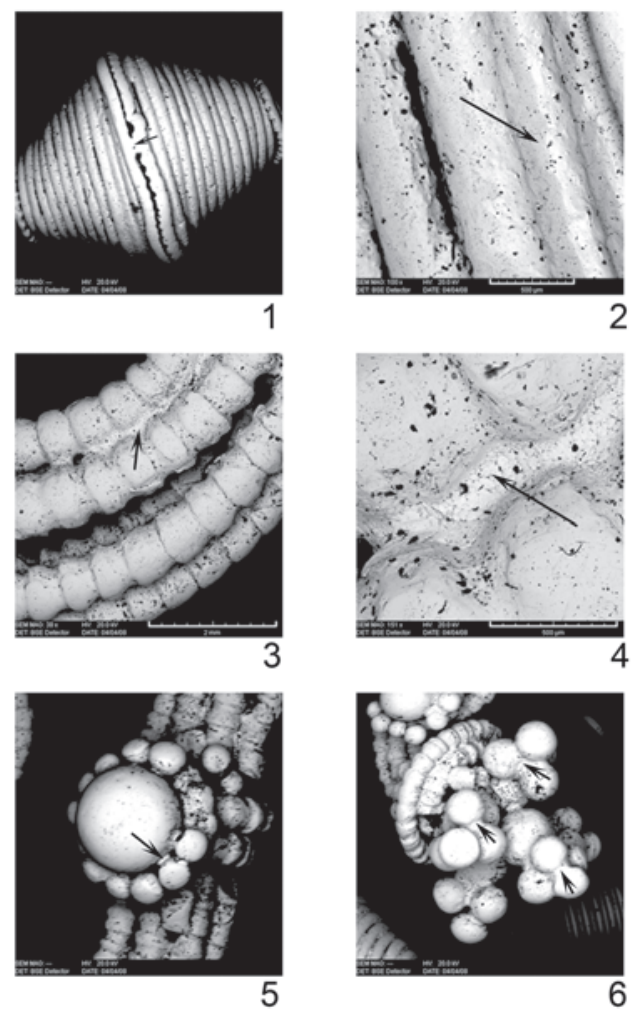

Fig. 14. Weklice, site 7, Elbląg commune. Selected finds decorated with filigree and granulation with visible (marked by arrows) places the solder joints to the substrate, so-called bridges: 1-2 - grave 208, gold filigree biconical bead; 3-6 - grave 208, gold S-shape clasp (photo E. Pawlicka) 
trace elements) (Walenta 2009, 216). On the other hand, it should not be excluded that the last two artefacts were made of low-gold alloys.

We need to discuss certain decorative elements (on brooches and, more rarely, pendants) in the form of gold or silver gilded foils, both stamped and smooth, on a silver, iron or copper alloy base separately (Figure 2: 1-4). The results of analyses indicate the use of gold of varying fineness. This could only be determined as a result of the analytical method used, which required mechanically rubbing off the surface of the examined object to determine whether gold or silver gilded foil had been used. The state of preservation of the artefact is also a factor. Silver fire-gilded foils exhibit significantly higher corrosion levels. They are contaminated with corrosion products of tin, zinc, lead - solder residue - and copper, if the core of the artefact was made of copper alloy. That is why the silver forming the base of the foil is sometimes visible on the surface. In the case of gold foils - they have a uniform golden color (cf. Fig. 2:4). Whereas the differences in chemical composition are the result of sampling from the thin (c. $0.3-0.5 \mathrm{~mm}$ thick) parts of the complete artefact.

Despite these reservations, it must be said that, as in the case of solid metal artefacts, the highest quality raw materials were used in the production of foils. To make gold foil or gilt for silver foil, a high-quality gold is required. It must be soft enough to be sufficiently malleable for plastic processing to make such thin foils or to gild silver foil. However, it should not be excluded that foils with similar proportions of silver and gold, also characterized by a uniformly pale, golden color, were also made of electrum (Strobin 2007, 675).

\section{SILVER, ITS ALLOYS, AND SILVER FOILS}

Silver (chemical symbol Ag) is a noble metal, in contrast to gold, and is found in nature in its "pure" state, the so-called native silver, though very rare, is almost always contaminated. As in the case of gold, silver with a fineness of 1000 exists only theoretically and the impurities in the known nuggets range from $0.1 \%$ to $1 \%$. The highest laboratory value of silver is currently 999.999. It is most often found and extracted in ore deposits (mainly in ores of gold, copper, lead and zinc as well as platinum). Compared to gold, it is a slightly harder and more brittle, but still very ductile and easy to work by cold forging. It has a silvery-white color, lustrous after polishing. Like gold, "pure" silver is too soft to be used in further goldsmithing. Consequently, it is hardened (as in antiquity), by mixing with various metallic elements. Mostly, the basic alloy component is copper in the metallic state. The other most commonly found metals in silver alloys are zinc, cadmium, manganese, nickel and palladium, and less often antimony, tin, chromium, magnesium and aluminum. Sulfur, arsenic and bismuth are harmful admixtures because they do not dissolve in the silver when heated and make the alloy brittle and therefore unsuitable for further forging (Knobloch 1977, 92-93). Silver, in contrast to gold, is more susceptible to corrosion and less resistant to atmospheric influences; it blackens under the influence of sulfur compounds (hydrogen sulphide). 
Silver alloys are alloys in which the basic metallic element is silver if its content is at least $10 \%$. The main component of silver alloys is copper, which forms a solid grain boundary solution with silver, with their mutual solubility decreasing with the drop in temperature. Consequently, in goldsmithing, heat treatment is used to improve alloys, by saturation or tempering (Knobloch 1977, 78).

For the purpose of this work, 68 artefacts were examined, both made of solid silver and decorated with filigree, granulation and stamped or smooth foils applied on substrates made of other metals (Figure 2: 2-4; 3: 1-4; Table $2-C D$ ). Reviewing the results, we see immediately that the alloys used in the ornaments had a high silver content, both for the basic parts (e.g. bows of brooches, bracelets) and for structural parts (pins, springs). Fineness oscillates between about $92 \%$ to $98 \%$ silver content in the alloy. The metal was of high quality, technically pure, such as is even today rarely used in jewelry making. Currently in Poland, according to the assay law, the highest fineness grade for silver, expressed in parts per thousand is 925 or $92.5 \%$ pure silver in the alloy. The alloy of silver with such high fineness values as in the analyzed artefacts was very forgeable and malleable and therefore easy to work. In order to harden the alloy, copper was usually added (c. 2-7\% of the content in the analyzed alloys). Aluminum, sulfur, chromium, manganese, iron, nickel, zinc, gold and lead are also found in small proportions. With the exception of sulfur, iron, zinc, gold and lead, which may have been, but did not have to be an admixture to improve further treatment of the alloy, the rest were rather a component of the native ore. These high grades of fineness are consistent with the technology of the analyzed finds, in particular the faceted and semi-circular in cross section bows of silver brooches from groups II and V distinguished by O. Almgren, and the springs of brooches in Almgren's groups VI and VII, as well as the later forms of Schlangenkopf (snake-head) bracelets (groups II-V with subtypes distinguished by T. Wójcik). These were usually forged in shape forms from previously cast bars (Figure 4: $3-5$ ), so the material needed to make them had to be very plastic and forgeable.

Lower grades of fineness, between 92-94\%, occurred mainly in artefacts decorated with silver foil. In this case, as with the above analyses of gold and gilded foils, it can be concluded that due to the analytical method used, the result may be slightly falsified.

\section{COPPER AND ITS ALLOYS}

Copper $(\mathrm{Cu})$ is a semi-precious metal, soft, with very good conductivity of heat and electricity and a melting point of $1083^{\circ} \mathrm{C}$. In nature, as a mineral, native copper rarely occurs in a "pure" state, and is usually contaminated with lead, iron, nickel, tin and zinc about $0.01 \%$ to $1 \%$, most often being found in ores. It is quite chemically resistant, is not affected by acids under anaerobic conditions. Under moist conditions (both with and without oxygen) it forms a layer of green patina, commonly referred to as "noble" (this is a compound called hydroxide carbonate $\left.\mathrm{Cu}(\mathrm{OH})_{2} \mathrm{CO}_{3}\right)$, which prevents the corrosion of deeper 
layers. Exposed to air it corrodes, often becoming covered with a thin layer of copper oxide $(\mathrm{CuO})$ and as a result growing darker and turning a reddish brown. Copper can also corrode if exposed to an environment containing sulfur compounds, especially sulfur dioxide (SO2); then a black tarnish forms. The metal, in the form of pure copper, possesses considerable forging qualities suitable for goldworking, but is very soft. It can be processed both in its cold state and when heated. In jewelry production and in industry, both now and in ancient times, copper mainly occurs in the form of alloys.

Archaeometalurgical researchers adopt various nomenclatures for "bronzes", mostly adapted to modern terminology. The expression "bronze" or made of "bronze" are used here only in the common sense of the word, only as a description of the metal and its color. As shown by the attached analyses of objects made of copper alloys, most of the artefacts were made of other types, mainly brass.

Although metallographic research and the interpretation of the results of copper alloy analyses have a long tradition (cf. Bayley, Butcher 2004; Bezzenberger 1904; Niewęgłowski 1986; 1988; 1991 - with extensive literature), no uniform methods have been developed for the interpretation of chemical composition, particularly in the classification of raw material groups, alloys used in metal production. The basis for distinguishing specific groups is the type of alloy, which is defined by taking into consideration the intentional components, determined by the nature of the ore deposits. The latter method, however, is highly controversial because of the limited information available about the primary ore deposits and the frequent use of scrap metal in the alloy. Already in Roman times many varieties of copper alloys were known. From Pliny we know that Roman craftsmen were aware of which copper alloys could be used for forging and which for casting, and adapted them to the techniques used for making vessels and other objects, and what follows, their physicochemical properties were also exploited in the production of various categories of objects, depending on the technology of production and practical experience of individual manufacturers (Niewęgłowski 1986, 312; 1988, 191). In this article, three basic groups of copper alloys are distinguished on the basis of analyses of their chemical composition (cf. Table $3-\mathrm{CD}$ ).

Bronzes - are copper alloys containing various alloying metals, other than zinc (Zn) and nickel (Ni). In antiquity the most widely used were tin bronzes, also commonly referred to in the archaeological literature as "classic bronzes", defined as 90\% copper and $10 \%$ tin. Tin bronze contains from $1 \%$ to $10 \%$ tin with an appropriate percentage of copper and with other metallic elements (mostly lead) occurring in trace amounts. There were also bronzes with a tin content of 10 to $13 \%$ which could be worked both by forging and casting (Niewęgłowski 1986, 312).

Lead-tin bronzes (red bronzes or gunmetals), often classified as tin bronzes, are copper alloys containing approximately equal or greater tin content $(\geq 13 \%)$ than tin bronze (from $10 \%$ to $13 \%$ ), and, moreover, in which the basic component is zinc (in varying proportions of about 2-9\%) and lead (in varying proportions of 2-8\%). The above proportions are based on contemporary Polish tin bronze standards (Dobrzański 1993). Analyses of finds show 
more diversified proportions. This is due to the applied method of chemical analyses and, above all, to the recipe worked out by a given manufacturer.

The bronzes described here, usually of a copper, slightly silvery color, are difficult to cold forge (they were often considered harder than iron) but can be hot forged (up to $600^{\circ} \mathrm{C}$ ). However, they have the best casting properties and are excellent for machining as they are resistant to abrasion and corrosion. In the Roman Empire these types of bronzes was used mainly for the manufacture of vessels, as evidenced by the vast number of analyses of Roman bronze vessels (cf. i.a. den Boestred and Hoekstra 1965; Drescher 1958; Hammer and Voss 1997; Laurenze and Riederer 1980; Niewęgłowski 1988; Riederer 1984; Riederer and Breise 1972). With this category of bronzes compound copper alloys with tin, zinc and lead, numerous in antiquity are inseparably associated. Andrzej Niewęgłowski as multicomponent alloys regards bronzes with an admixture of zinc or with a predominance of tin over zinc. If zinc predominates over tin, then the alloy is classified as brass with a tin admixture (Niewęgłowski 1986, 316; 1991, 300). However, the lack of a percentage determination of the predominance of particular elements in an alloy raises doubts about attribution to specific categories. The alloys were produced by combining zinc ore (galman) with melted tin bronze, or by melting separately the bronze and brass obtained, or by melting scrap metal made from the above mentioned alloys (Glazer and Okulicz 1955, 308). Due to their strength, such three and four-component alloys had high technological properties. They were suitable not only for casting at $800-1000^{\circ} \mathrm{C}$ but also for metalwork processing. According to raw materials research, in the Roman Empire such alloys were most often used for the manufacture of small ornaments and various accessories (Niewęgłowski 1986, 316; 1991, 300).

Brasses are copper alloys, whose main alloying component (apart from other metallic elements in different proportions like lead, aluminum, tin, manganese, iron, chromium and silicon) is zinc in ratios of more than $2 \%$ to a maximum of $45 \%$. In Europe, zinc as a deliberate addition to copper appeared in pre-Roman times. Earlier it occurred as a natural additive smelted from copper ores. However, in the times of the Roman Empire, in view of the possible lack of expertise in smelting metallic zinc, it was necessary to use zinc ore and zinc oxide to produce brass, which prevented metallurgists from fully controlling the composition of the alloy (see Nieweggłowski 1986, 313-318, and more on the possibilities of obtaining metallic zinc by ancient metallurgists in Bochnak 1997 - with extensive literature).

Classic brass is golden (its common use in antiquity was probably because it imitated gold), but with smaller zinc content it approaches the natural color of copper. This alloy is resistant to corrosion, ductile, easy to work - forgeable. It has very good casting properties. Ancient brasses may contain up to several and more percent lead; then they are referred to as leaded brass.

Written sources testify that two methods of producing brass were known. Zinc ore (usually galman) or zinc oxide was added to the copper. Zinc oxide formed during the ore 
smelting process when the zinc vapor reacted with oxygen and accumulated in the upper part of the furnace in the form of build-up, so-called cadmia. Hence, in ancient writings two types of cadmia are mentioned: cadmia mineralis, that is zinc ore, specifically galman, willemite, maybe also sphalerite, and furnace cadmia, also known as furnace accretion (Krawczuk 1956, 20-21; 1957, 285). By adding zinc oxides to copper one can obtain brass with a maximum content of between 30\% to 40\% zinc (Niewęgłowski 1986, 315; Maréchal 1961, 266; Picon et al. 1966, 1969). Above this value, the zinc oxide molecules do not bind with the copper molecules. These are so-called single-phase alloys of "a" structure. This phase directly from the liquid state and the maximum zinc content does not exceed $39 \%$. (Dobrzański 1993, 427). Single-phase brasses are characterized by high plasticity in cold and hot processing and at the same time are relatively hard. With up to $20 \%$ zinc in the alloy composition their technological properties are similar to tin bronzes, but their forgeability is higher. Above $25 \%$ the plasticity and strength of the alloy increases. As the zinc content increases, the alloy fusion temperature decreases. It is $1050^{\circ} \mathrm{C}$ for brass $20 \%$ and just $950^{\circ} \mathrm{C}$ at $30 \%$. The color also changes - with up to $10 \%$ zinc, the alloy retains its copper color, between $15-20 \%$ it resembles gold, with about $25 \%$ it becomes a slightly greenish gold color and when the zinc content is 40\% it again becomes golden (Picon et al. 1966, 191) In Roman times, the zinc (in ore deposits) was relatively cheap. It was more common than tin, which was extracted only in the Iberian Peninsula, Britain, and Asia Minor. Its price was ten times lower than the price of tin and half the price of copper (Maréchal 1984, 22). Zinc ore was extracted from deposits lying between the Somme and the Meuse, in Italy, Gaul and Germania (Glazer and Okulicz 1955, 308; Domergue 2008). In brasses produced in the Roman Empire, as well as in coins, the zinc content sporadically exceeds 20-25\% and is never more than 28\% (Caley 1964, 69-76, Maréchal 1984, 21; Picon et al. 1966, 191).

The chemical composition of 52 finds made of the copper alloys described above (Figure 5: 1-10; Table 3) were analyzed. These were primarily ornaments and dress accessories: brooches, Schlangenkopf and rod bracelets, buckles, belt end fittings, pendants, capsule and other, beads, rings, boxes, spurs. Most of them were typical of the Wielbark culture. A collection of items imported from the Roman Empire was also analyzed here and discussed in detail below.

The results of the analyses indicate that the copper alloys used varied greatly in the proportions of component elements. This is the result of the physicochemical properties of these alloys because, unlike noble metals, copper alloys, although created intentionally, are very heterogeneous from a chemical point of view. The properties of such an alloy are influenced primarily by the type of components used and their proportions. Adding a component with a high melting temperature results in an increase in durability (creates a finer grain structure), while the addition of an easily meltable ingredient is completely counterproductive and may even prevent further working. Metal of a lower mass density affects the mass density of the alloy by lowering it, while a heavier metal usually increases it. 
However, this is not always the case with copper alloys, as the density of the alloy varies in proportion to its composition. Thus, depending on the composition of the alloy, it can have a different structure even if it consists of the same elements. The effects of individual components can vary, depending on their percentage content and the main alloy component and other alloying additives (see more in Knobloch 1977, 85-86). Therefore, when using the X-ray fluorescence method, analyzing at several points of the sample (e.g. of the brooch bow) yields different results as to the content of the alloying elements, but within the defined basic proportions of the discussed alloys, nevertheless attesting to their heterogeneity.

In general it should be noted that in all categories of analyzed local finds from Weklice and cemeteries in the area, characteristic of inventories of the Wielbark culture, one group of raw material was used. These are brasses (cf. Table 3), also leaded, where the basic zinc alloy component varies between $4 \%$ and $23 \%$. With a few exceptions, there are no high alloyed tin bronzes, in which the proportions of copper and tin would be consistent with the one described earlier. The use of brass with similar proportions of components is noticeable throughout the period of functioning of the cemetery at Weklice and testifies to a specific craft tradition and the use of one developed technological process, determined by the selection of the best raw material, with similar physicochemical properties.

These results do not differ significantly from other analyses of barbarian artefacts from Poland from the same time as the Weklice cemetery. The chemical composition of copper alloys in a large number of finds from various sites was analyzed. Among the sites of Przeworsk and Wielbark culture cemeteries were Nadkole, site 2, Węgrów Comm. and Modła, Mława Comm., Oblin, Garwolin Comm., Kamieńczyk, Wyszków Comm., Grzybnica, Koszalin Comm., Krupice, Bielsk Podlaski Comm., Święty Gaj, Elbląg Comm. (Andrzejowski 1998, 125-130; Czarnecka 2007, 128-130; Dąbrowska 1997, 78-79; Hahuła and Wołągiewicz 2001, 43-46; Hensel 1998, 141-147; Jaskanis 2005, 127). Similar results were obtained for a series of dozens of objects from cemeteries of the Oksywie and Wielbark culture in Pruszcz Gdański, site 10, Pruszcz Gdanski Comm. (Pietrzak 1997, 76-78), and Czarnówko, Nowa Wieś Lęborska Comm. (Gan 2015, 175-214). Recently a collection of artefacts from the hoard discovered at Łubiana, Kościerzyna Comm. were analyzed. The results were compared with the results from the just mentioned sites and from selected Roman castles (cf. Mączyńska 2011; Hammer and Voß 2011, 210-229). In conclusion, it should be stated that the results of the analyses from the above sites are quite consistent with the Weklice material and from other sites of Wielbark culture on the Elbląg Heights.

The metallographic spectral analyses of artefacts of the Wielbark culture carried out earlier on material from the barrow cemetery at Odry, Chojnice Comm., require a separate discussion. They were published without any comment, only in the form of tables (cf. Kmieciński 1968, 126-128) and showed that among the objects made of copper alloys, tin bronzes were used with 86-90\% copper and 7-10.5\% tin. However, in each case that was analyzed, zinc was found (1.5-4.5\%), which by definition should not be a component of such an alloy. While in the silver artifacts, the actual silver content was very low $(73-89 \%$ 
silver with 10-26\% copper and small amounts of zinc and other trace elements). Assuming these last results are credible, it should be emphasized that alloys of such proportions are very brittle and not very malleable. Such a low silver content contradicts the technique used to produce the artefacts being analyzed, since most of them were finished by hammering, a method which requires very plastic and ductile material and therefore of high fineness. It should be inferred that these analyses were performed incorrectly and that they should therefore be repeated using more sophisticated X-ray spectrographic analysis methods. Similarly, the Wielbark finds from Kowalewko, Oborniki Comm. (cf. Skorupka 2001), analyzed in recent years, require a second examination. The items from Kowalewko were analyzed using two methods: non-destructive X-ray microanalysis (EDXS) and atomic absorption spectroscopy (AAS). Only the content of the basic elements of the alloy, known by definition, was determined, not taking into account others which may significantly influence the determination of the original composition (cf. also Nosek and Kowalska 2001, 437). The interpretation of these results is very cursory and very generalized as far as defining the groups of raw materials used, and therefore cannot be the basis for comparisons with the material being analyzed. The results of these analyses clearly indicate that the selection of artifacts was quite accidental, with no specific research objectives. The investigations also contain basic errors from the point of view of metallographic research. For example, the curious interpretation of the chemical composition of brooch A.V.124 from grave 227. In the catalog of grave inventories this fibula is described as silver. There is further information that the crest-head of the brooch was adorned with a silver filigree, without specifying whether the wire was beaded, twisted or smooth - this is also not apparent from the drawing and the photograph of the find. In the further part of the description, it is stated that the bow was entirely cast from pure (sic!) copper (cf. Nosek and Kowalska 2001, 438; Skorupka 2001, 66, tabl. 69:227/1).

A more extensive discussion is required in the case of a group of artefacts imported from the Roman Empire and the provinces, discovered in the cemetery at Weklice. These are primarily brooches, vessels and their fragments, belt fittings and coins (Figure 6: 1-6). The purpose of these analyses was to compare, using the same method, local copper alloys with Roman "bronzes", discovered in a similar geological environment (at the same site) and preserved using the same chemicals. However, above all, it was about identifying potential regularities in the use of similar compositions and the type of raw material in the technological processes of Roman and barbarian production. It must be stressed that the selection of imported finds was based on the chronological context of the graves in which they were discovered, so, as in the case of local artefacts, efforts were made to take into account the different stadia when the cemetery was in use. It also had to be taken into consideration that the time when imports arrived and circulated in the lands of Barbaricum was completely different from the time of their production in the Empire and its provinces (more Wielowiejski 1970, Wołągiewicz 1970a; 1970b), and that the same holds true for Weklice. 
The results of these investigations have shown decisively that all the analyzed artefacts differ significantly in chemical composition from local finds and, on the other hand, show great similarity in the alloys used (in each category of imported finds). Copper alloys, which can be described as tin-lead bronzes, were used to make imported brooches. Such alloys are characteristic of the western provinces of the Roman Empire (Niewęgłowski 1988; 1991; Stos-Gale 1993, 101-131), and also of the British Isles, where an enormous collection of Roman fibulas has been analyzed (Bayley and Butcher 2004, 220-229).

Additional comment is required in the case of a set of belt fittings, found in grave 208 at Weklice (for more see Natuniewicz-Sekuła and Okulicz-Kozaryn 2007, 54; 2008, 243). From other "bronze" artifacts produced in the local workshops, the buckle frame and the belt end (Figure 7: 1-2) are distinguished by their noble patina of a unique olive-green color. In addition, their surface is perfectly polished, lustrous. Analyses showed that they were made of tin-lead bronzes. However, it is worth noting the different composition of the buckle plate, similar to the brass composition of which local artefacts were made. It should also be taken into account that the buckle has evidently been repaired, probably due to damage to the original plate. One knob on the pivot of the frame is original and the other made later. In addition, it's form is typical for knobs on the pivots of buckles and ends of brooch springs found at Weklice. Here we clearly have a find which has been repaired in Barbaricum and probably locally. Likewise, the belt end was repaired as the original one was broken. The point of breakage was carefully filed and polished. This whole set of belt fittings was probably repaired and continued to be used. Both of the finds described here have no obvious analogies in Roman and provincial Roman materials; only stylistic imitation can be traced. This fact seems to argue for an origin from a barbarian workshop, but located closer to the limes (cf. more Natuniewicz-Sekuła and Okulicz-Kozaryn 2007, 54).

The use of tin-lead bronze alloys was also noted in the composition of vessels. In all cases, material for analyses was taken from the bodies of preserved fragments. However, in contrast to the described brooches and belt fittings, they were found to have a significantly lower lead content, not exceeding $1 \%$. Such results of analyses of these Roman vessels do not differ significantly from the numerous analyses of other "bronze" Roman vessels discovered in Poland, which, both in the Empire and in the Roman provinces, were generally made of tin-lead bronzes (Niewęgłowski 1991, 281-286, table I).

Another interesting discovery were dozens of fragments of a unique pitcher in the Egyptian style (cf. Natuniewicz-Sekuła 2010, where a broad overview of the find and its dating, origin and cultural background). Already on the basis of preliminary macroscopic observations, it can be stated that the alloy of which the vessel was made differs from the other "bronze" Roman imports discovered at the cemetery, and is similar in color to local artefacts. In addition, most of the fragments were covered on the inside with a thick layer, $0.5^{-2} \mathrm{~cm}$, of gray metal, which analyses confirmed to be lead. Chemical examination have shown that the basic material for this vessel was a copper alloy (about 85\%), zinc (about 
10\%) and lead (about 5\%). This chemical composition makes it possible to approximate the alloy as a lead brass. Thus, it is the only Roman vessel with a composition similar to the local artefacts.

Roman coins (subaeratii) from Weklice (cf. Fig. 6:4-6) also require further comment. The alloy of two coin cores, drilled in the central parts, was found to be composed of about $75 \%$ copper, between $0.1-3 \%$ zinc and varying amounts of tin, once about $4 \%$, and then about $20 \%$, and lead about $4 \%$ and about $10 \%$. The analysis of the cladding, obverse and reverse, was interesting. In all cases, the coins were covered with tin-lead cladding with a tin content of more than $40 \%$ and lead of about $20 \%$, trace amounts of silver, and a small amount of platinum, $0.82 \%$. The alloy composition of these coins should be regarded as close to red bronze, i.e. lead tin bronze alloy. The coating was probably intended to imitate the silver plating common in denarii subaerati. Tin was used to replace silver as a more economical metal for mass produced denarii (for more on denarii subaeratii see Bursche et al. 2000, 112; Gitler and Ponting 2003, 33).

\section{TIN COATINGS}

A separate group of analyzed finds were brooches whose bows were made of brass and covered with a coating of tin (Fig. 8: 1-3). All belonged to one type, similar to types A. 116117. They represent the so-called Bornholm series 11 of group V in Almgren's classification, or more precisely the Leonów type distinguished by Rudolf Jamka (1963, 70-73).

The tin layer, where it has been preserved, is usually thick and characterized by a light silver shiny hue over the whole surface of the item. In one case, $68.39 \%$ of tin, $1.36 \%$ of lead, $\mathbf{0 . 7 8 \%}$ of silver, and the remaining trace elements of copper alloys were recorded. $54.1 \%$ of tin, $36.47 \%$ of silver, with a low copper content of $7.14 \%$ was noted in the second. Variations in copper content are due to the thickness of the tin coating, where it is thinner the copper content rises and where thicker decreases. This is the result of the analytical method used, as electrons passing through the thin coating measure the elements of the base alloy from which the artefact was made. The bow of a brooch of Leonów type from grave 6 in the cemetery at Ulkowy, Gdańsk Comm., was covered with a thick tin coating? (no chemical analysis was carried out) (Tuszyńska 2005, 13, pl. III: 6/1). The description suggests that the brooch is silver plated. Taking into account the presence of a large amount of silver in one of the samples from Weklice described above, in the case of Ulkowy we may have an instance of tin plating with a high silver content, which is technologically possible. Two further two tinned? brooches of the Leonów type come from the cemetery at Kowalewko - graves 375 and 386 (Skorupka 2001, 101, 104; pl. 118:375/1; 123:386/2). As in the case of grave 6 at Ulkowy, the chemical composition of the coating was not investigated, therefore one of the Kowalewko brooches (grave 375) is described as tinned and the other (grave 386) as silver plated. Knowing all the described artefacts from personal observation, I rather favor the option of tin coatings in these cases. However, it is worth pointing 
out that at Weklice, Kowalewko and Ulkowy, as well as in other cemeteries from the Pruszcz Gdański region, west of the mouth of the Vistula, brooches of the Leonów type have been found sporadically which were made of copper alloys or iron and decorated with silver or gilded foil. Consequently, the question arises as to whether the preserved layer is not simply a residue of the solder binder used to apply the foil (analysis of the Weklice material has shown tin-lead solders). As we know, tin dissolves silver (especially thin foil) and diffuses into its structure, particularly when overheated. This situation can most probably be ruled out because all the known to me remnants of solder binders in different categories of artefacts are preserved vestigially, in the form of irregular thin layers, concentric clusters, efflorescences on the surface of artefacts. Moreover, solder binders do not have a light silver shiny, polished color and are generally strongly saturated with the green corrosion of copper compounds whereas the preserved coatings are quite thick and very uniform, which excludes the possibility that the bows of these brooches were decorated with foils.

As shown above, tinning is very rare in Wielbark material and is generally only recorded on a similar type of brooches that are not typical forms for the inventory of this culture. It should therefore be assumed that the just described type of brooch is not connected with local production and that its appearance should be associated with intensive contacts of the Vistula estuary region with Scandinavia. Numerous brooches of the Almgren 116-117 types, considered as transitional to the Leonów type, both "bronze" and iron, often decorated with impressed gold and gilded foils were discovered in Scandinavia - Jutland, Bornholm (Almgren 1923, 230-231), and their mostly plain iron counterparts occur as frequently in assemblages of the Przeworsk culture in Greater Poland and sporadically in Upper Silesia (Godłowski 1977, 22; Jamka 1963, 70-72). In the Wielbark culture they appear at Weklice - graves 267; 494 (Natuniewicz-Sekuła and Okulicz-Kozaryn 2011, 78, pl. CXIII: 1-2 and unpublished materials from Magdalena Natuniewicz-Sekuła's research in season 2005), Kowalewko, grave 356 - here with granulated ornament on a silver plate soldered to the head of the brooch, grave 375 - one of a pair, decorated with silver foil impressed in geometric patterns (Skorupka 2001, 95, 101; pl. 109; 118), Ulkowy, grave 59 here without ornament and grave 70 with silver gilded foil impressed on a filigree die with motif of plaited and beaded wire (Tuszyńska 2005, 25, 28; pl. XXIII, XXVIII), Pruszcz Gdański, site 10, grave 64, in the catalogue incorrectly described as A.V.151, with preserved silver impressed foil, and grave 287 also decorated with silver impressed foil (Pietrzak 1997, 19, 46, pl. XIV, C).

Considering the numerous tin coated artefacts whose origin can be traced to Rome and its provinces, it can be surmised that the technique of tinning, which in the Wielbark culture was used only on brooches, originated in the lands of the Roman Empire, where its first and foremost use was to coat vessels made of copper alloys. The tin coating was most often applied on the inside of bronze vessels associated directly with the consumption of wine - especially pans and cauldrons used to heat it. This was most probably done to protect against the toxic properties of copper compounds of which the Romans were already 
aware. A set of wine drinking utensils (two glass cups, a copper alloy ladle, strainer and tin-coated saucepan) were discovered in grave 495 in the Weklice cemetery (cf. Natuniewicz-Sekuła and Okulicz-Kozaryn 2007, 2008). Roman mirrors, mass-produced in the large centers of the Empire and the provinces, for instance in Nijmegen, Cologne or Northern Italy, were also covered with thick layers of burnished tin coating (Lloyd-Morgan 1981; Meeks 1995). The presence of tin coatings and copper alloys with increased tin content has also been reported on brooches from sites in Roman Britain (Bayley and Butcher 1981, 32; 1989, 25-32; 1995, 113-119; 2004), that is from where, after the establishment of the new province, tin deposits were exploited and imported to continental Europe. In general it is believed that tinning was intended to imitate silver plating, thus imparting a more refined and luxu-rious appearance (Strobin 2007, 675-676). However, it should be emphasized, that there are no silver-plated items in the Wielbark culture, so here we are dealing exclusively with imitation silver foil.

\section{THE GOLDSMITH WORKSHOP AND TECHNIQUES OF PRODUCTION}

The greater part of the Wielbark culture inventory comprises ornaments made from alloys of copper, also silver and gold, which underwent significant stylistic changes and technological improvements as the culture evolved. The inventory of the Early Roman period contains ornaments mostly made of copper alloys (mainly brass), a few decorated and inlaid with silver, and with rare elements of gold, while towards the end of the Early and beginning of the Late Roman periods came the greatest development of goldsmithery. At this time we see the widespread use of advanced decorative techniques for ornaments and dress accessories, such as gold and silver filigree and granulation, as well as decorative foils, and in literature on the subject the period is referred to as the "Wielbark baroque" (Wołągiewicz 1974). Apart from the few works by J. Strobin (1995; 1998; 2000; 2007; 2015), research concerning goldsmith production technology in the Wielbark culture has to be viewed as inadequate considering the almost complete lack of information about remains of workshops in the area, including smitheries and the tools used in them. A thorough overview of European smith's tools, from our period of interest, from graves and bog deposits, are given by A. S. Dobat (2008) and Andrzej Kokowski (1981). Many of these implements could have been used also in goldsmithing. Much more is known about goldsmithing and metallurgical workshops in the area of the Przeworsk culture, though here too the data are insufficient. Finds include single crucibles, fragments of casting molds and of semi-finished products, as well as and waste of raw materials are discovered. Bronze and goldsmith workshops are also known from Barbaricum sites occupied by other Germanic cultures (cf. Bochnak 2000, 89-90). Excellent comparative materials for the reconstruction of goldsmith workshops are provided by Roman and Roman provincial materials, in particular the descriptions of tools from Roman camps (cf. more Pietsch 1983) and a huge 
series of non-ferrous metalworking tools from Danish bog sites such as Illerup Ådal and Vimose from the period of the Roman Empire (for more see Dobat 2008 - with extensive literature).

It is known that the goldsmiths instrumentarium included a broad spectrum of tools such as casting molds, crucibles, casting spoons, bellows, pincers, hammers, scissors, anvils, drawn-plates, dies, whetstones, punches, whetstones files and many more. Undoubtedly, the makers of non-ferrous metal objects had a great deal of practical knowledge, which allowed them to achieve the optimum conditions for melting alloys and the ability to produce tools, also iron tools, as well as ornaments, dress accessories and items of everyday use.

\section{CASTING}

The most common method of casting was the lost wax method. In this case, a model of the desired object was formed out of a soft mixture of beeswax with mutton tallow and oil (Oldeberg 1966, 259). Probably already then various types of wax were used: soft for the easier modeling of various shapes and hard wax for carving ornaments on the model. The next step in the process was adding such elements as sprue and ventilation ducts. The model was then carefully covered with clay leaving sprue and vents open. In the case of molds for single items, the ventilation ducts were made directly in the wet clay mold by puncturing several holes with thin wire. The resulting form was dried and fired in a forge hearth or furnace. No high temperatures are required for this treatment, the wax runs out at 150$200^{\circ} \mathrm{C}$. After the wax melted, the negative of the object was imprinted inside the mold. Then, the molten metal alloy was poured from a crucible into the empty clay mold cavity. Experiments carried out as part of this study resulted in, statistically, slightly over half out of ten castings being successful, with casts suitable for further working. Everything depended on choosing the right composition of raw materials for the alloy, appropriate conditions and controlled maintenance of the temperature in the forge hearth or furnace. As demonstrated by the experiments, an extremely important step in the process of obtaining a good cast was suitable preheating of the mold, before pouring the molten metal at $800^{\circ} \mathrm{C}$. This was necessary to balance the temperatures, as the hot metal in contact with the cold form began to cool quickly, causing the cast to fail. Experiments showed that specialized foundry workshops had to meet the relevant requirements. First of all, they were secluded, roofed buildings, sheltered from strong winds but at the same time with good ventilation. It was also important to use the best high-calorific charcoal or deciduous wood (oak, ash), and the quality of the cast itself required a great deal of experience and skill from the caster and his assistants.

Clay molds used in the lost wax casting method were disposable because to extract the product, the cast had to be broken up (Fig. 9). However, reusable clay molds are known from Roman times. Their reuse, even multiple times during casting, was possible with the use of two-piece molds. Such molds, used for the casting of brooch plates, have been dis- 
covered in Britain (cf. Bayley and Butcher 2004, 27, fig. 9, pl. 1) and elsewhere. Mostly, however, they were one-piece specimens. In the areas of Barbaricum, with particular regard to the Wielbark culture, there are no finds of two or multi-part stone casting molds, characteristic of early Slavic culture (cf. Szmoniewski 2005). The exception is a stone casting mold (probably made of limestone or lake marl) dated to the Late Roman period, discovered at a cemetery of the Bogaczewska culture at Paprotki Kolonia, site 1, Giżycko Comm., in grave 29. The study does not include an illustration of the find, or a detailed description telling us what elements were cast in this mold (Karczewski 2011, 133-134).

However, already in ancient times, in the founding of non-ferrous metals, clay forms were used to cast more than two semifinished artifacts at a time. The prepared wax models of the same semifinished artifacts were combined into a Christmas-tree-like shape, joining the individual infeed channels into one main one and making a suitable number of additional air vents. The basic rule is that the greater the number of well placed air vents, the better the cast. Making an adequate number of venting channels helps to avoid bubbles of oxygen getting caught inside the molds and leaving empty spaces, so-called pores within the cast. A cast with pores becomes brittle and prone to cracking during further working.

The multi-element clay molds used for castings the brooch plates, together with the preserved semi-finished products, come from, among others, the Celtic oppidum in Bibracte, where fully-preserved foundry workshops were discovered. The foundries were also active during the Roman domination in Gaul (Pernot 1998; Romero 2006, 78-79). In the immediate vicinity of Bibracte, in Autun, Burgundy, a Roman deposit of 280 kilograms of fragments of brooch casting molds were discovered. The brooches were Hull's type 21 and 26, corresponding to the following types: Almgren 240, Riha 4.5, Ettlinger 24; Feugère 19 (Hull, Hawkes 1987). There were single and multi-part forms as well as multi-element forms (Chardron-Picault and Pernot 1999, 159-162). From the areas of the Roman Empire and continental provinces, the presence of clay molds, predominantly single-element, for casting Roman brooches and semi-finished products, from the areas of the Roman Empire and continental provinces, is fairly well documented (cf. continental findings in Bayley and Butcher 2004, 37-39, pl. 12). Quite a large collection of one and two part clay molds for casts of brooch plates comes from Roman Britain (Bayley and Butcher 2004, 26-28). From there we also have single and multi-element molds for casting silver and bronze spoons (Bayley 1995, 105-107).

The use of multi-element clay molds in the Germanic territories in Late Antiquity is also confirmed by the find of a crossbow brooch with extended foot coming from a caster's hoard discovered in Frombork, Braniewo Comm., dated to the Migration period (cf. more Godłowski 1972, 57-69). It was a semi-finished brooch bow with a sprue mark at the end of the foot. At the other end of the sprue there is a broken off fragment (of rectangular profile) of a second foot, probably of an analogous brooch (Fig. 10: 1-2).

In the Wielbark culture lost-wax casting was used mainly to produce semi-finished brooch bows, belt end fittings, buckle frames or early forms of Schlangenkopf bracelets. 
Since there is little information about remains of Wielbark workshops of non-ferrous metallurgy, we cannot say much about the development of this technique in the Wielbark culture. Nevertheless, one confirmation that serial molds were in general use is the discovery of a barbarian bronze casting workshop (dated to phase $\mathrm{C} 1$ ) in a settlement at Pasohlávka, Břeclav district, located not far from a rich grave in Mušov, in the Czech Republic. The excavated artefacts have evident ties to the Wielbark finds from around the Vistula estuary, among which was a series of clay molds for casting brooch bows of series 1 of Almgren group VII, some with an upper chord which is considered a Sarmatian form, and belt-end fittings type Raddatz J II 3-4 and J II 6-7 (Tejral 2006, 134-141). In the north-eastern part of Hungary, inhabited by German and Sarmatian settlers, at the Tiszaföldvár settlement, in a feature interpreted as a foundry workshop (Vaday 2005), a casting mold was discovered of brooch type A.V.128 - an evidently Wielbark form, often found in the inventory of that culture.

When the clay mold was broken, the rough cast needed further processing. Stubs of sprues, the channels for pouring and venting, had to be cut away and seams and other irregularities removed. Therefore, the cast needed more work such as filing, chasing, polishing and hammering in order for the final effect to be achieved.

Among the well-known finds of semi-finished artefacts are the already mentioned pieces from the Frombork hoard, dated to the migration of peoples, in which, besides the initially worked ornaments and dress accessories, cut and whole coins, lumps of raw material were also discovered (Ciołek 2007, 47-49; Godłowski 1972, 57-69). Botched casts and semi-finished brooches, as well as fragments of other objects come from a hoard found at Łubiana, Kościerzyna Comm. (Mączyńska 2003, 314-320, 2011; Mączyńska and Rudnicka 1998, 43, 45), which also included a large series of "Sarmatian" brooches with high catchplate and upper chord. Both hoards are interpreted as the property of bronze smiths. Another find of a semi-finished brooch plate, series 1, Almgren group VII with upper chord, with pouring and venting channels cut off, and similar to the specimens found at Weklice (cf. eg. graves 43, 256 - Natuniewicz-Sekuła and Okulicz-Kozaryn 2011, 34, 75-76; pl. XIX, CVII-CVIII), come from Slovakia, from the Bratislava-Devínska Nová Ves site (Elschek 2002, 259, fig. 6:6).

It should be noted, however, that in the manufacture of certain categories of ornaments, mainly brooches, belt-end fittings and buckle frames permanent molds were used. We know of single finds from Barbaricum and the Roman provinces of metal molds (predominantly of copper alloys) used for shaping the wax, from the artefact was then made, employing the method described above. The nearest place where such a mold was found is a cemetery of the Przeworsk culture at Prusiek, Sanok Comm., grave no. 24 (dated to the beginning of the Younger Roman period), with furnishings indicating a male burial, included a set of tools, evidently used for goldsmithery and consisting, among others, of a small hammer, a punch and two copper alloy molds, most likely used to shape wax models. One of them had a negative of a brooch with a high catchplate and upper chord 
Almgren group VII, referred to in the literature as a Sarmatian form. The other mold, ringshaped, probably served to cast wax models of rings used as connectors in a variety of objects, including casket handles, separators of chain links of horse bits, etc. It was found in the humus, but its character indicates that it could be associated with the original furnishings of this burial (Madyda-Legutko et al. 2007, 63, Fig. 6). Two other finds of copper alloy molds serving to form wax models of brooches series 1 of group VII from the Younger Roman period should be mentioned here. The first comes from the Germanic territories on the Elbe, from Neunheilingen-Ost, Kr. Unstrut-Heinich (Walther 1996). The second is half of a bronze mold for making two brooches discovered in Austria; the context of the find is unknown (Mączyńska 2011, 68).

A surprising find are models of brooches made of lead, instead of wax (e.g. the plate of a trumpet brooch from the Poole's Cavern site, Derbyshire, England), obtained from twopiece metal molds (Bayley and Butcher 2004, 28-30, fig. 14). The use of lead for shaping models is justified as the metal has a very low melting point. It can therefore also be used to make a clay mold, after having been clad with clay and burned. Lead models for making various small items have also been recorded at provincial Roman sites in continental Europe (Drescher 1973).

In order to make a cast, one first had to obtain metal in a liquid state. Small clay crucibles and casting spoons were used to melt the metal. In Poland, an item interpreted as a casting spoon was found at a settlement at Piwonice, Kalisz Comm., (Dąbrowski and Śląska 1956, 213-215).

If only a small amount of material was needed (as was the case with precious metals), up to $150 \mathrm{~g}$, a hollow in a piece of charcoal could be used, directing the flame at it with a wooden blowpipe. Larger clay crucibles had to be resistant to high temperatures (Gradowski 1984,55 ), and clay certainly has such properties. Whereas the melting point of the metal depended on the components of the alloy. Crucibles were placed on the hearth or in the furnace. In the absence of findings from the Polish territories confirming this method, it should be assumed that the crucibles were covered with clay lids facilitating the maintenance of controlled temperature. The use of crucible covers is confirmed by such findings as those from Xanten (the Roman settlements of Colonia Ulpia Trajana), where the crucible sets were used for brass smelting (Rehren 2003, 209-210).

Bellows were used to raise the temperature on the hearth or in the portable clay domed furnace. The bellows nozzles were wooden tubes at one end thickly clad with clay (sometimes a separate clay nozzle was made closely fitted to the wooden tube) so as not to cause singing as the temperature of the hearth rose. At the other end, the nozzles were connected to a leather bag by a leather strap. Despite the lack of data on the species of wood from which nozzles were made, experiments have shown that the best material for making the nozzle tube is the black elder tree. In Poland archaeobotanical studies have found the pollen of black elder at excavation sites from the Roman period (Lityńska-Zając 1997, 8o). The inner tissue of black elder wood is very soft and easy to remove in order to make 
a hollow tube and thus blowpipes could have been of elder wood or metal and their outlet would have been covered with clay to prevent singing or overheating. The shape of a goldsmith's bellows made of one piece of sheepskin is accurately described by Theophilus Presbyter in Book III, Chapter 4 (Kobielus 1998, 59-60). We should also mention the remains of clay casting crucibles, undoubtedly related to the described method of non-ferrous metallurgy. In fact, there are no certain findings in areas of the Wielbark culture, maybe with the exception of two clay crucibles discovered during recent excavations of a Roman period settlement at Lipianki, site 3, Kwidzyń Comm. One was preserved in its entirety, with a triangularly formed edge and clear traces of the vitrification of the internal walls under the influence of temperature and fine fused residuals of copper alloy pellets. The second was a fragment of a small bowl-shaped crucible with circular spout (Strobin 2015, 138, fig. $7: 3 ; 41: 3$ ). In addition, numerous remains of various horn, bone and metal tools (awls, borers, etc.), were found on the site. There were also tools which should undoubtedly be associated with goldsmithery, such as a small hammer and copper alloy halfproducts such as wires, tapes, bars, probably for making various objects, as well as the actual artefacts (cf. more Strobin 2015).

Unlike the Wielbark culture, well-proven crucibles come from areas of Przeworsk culture. Fragments of re-burned crucibles as well as whole specimens were found at Jakuszowice, Kazimierza Wielka Comm. Traces of non-ferrous metallurgy were recorded at this settlement throughout most of its existence, starting from A2 and A3 of the younger preroman period to phase $\mathrm{D}$ - the beginning of the migration period. However, the most numerous remains come from the younger and late Roman period - phase $\mathrm{C}_{1}, \mathrm{C}_{2}$ and $\mathrm{C}_{3}$ (Bochnak 2000, 90-91). The Jakuszowice crucibles show signs of having come into contact with high temperatures - traces of vitrification on the surface of the inner walls, as well as one case of a small lump of gold fused into the wall. The crucibles from the Jakuszowice settlement are small cups with a conical or slightly rounded bottom and an irregular, almost circular shaped spout. Some fragments of crucibles have polygonal and triangular spouts to facilitate precise measuring out of the liquid metal. They were made of a homogeneous ceramic fabric, gray with a small admixture of mineral or chamotte. Some of them carry traces of repair, that is, the crucible was covered with clay when its surface became so porous as a result of burnout that, without a new layer, the vessel would be unsuitable for further use. (cf. more Bochnak 2000, 84-90). Similar artefacts were also found at a settlement of the Przeworsk culture from the Late Roman period at Igołomia, Kraków Comm. (cf. more Dobrzańska 1990, 72-73).

The casting technique described was in principle the most common in colored metallurgy. But not very productive, as many castings failed, and the remelting of the raw material resulted in considerable contamination of the alloy. In the course of several recastings, not only the copper but also the precious metal alloys lost much due to the evaporation of the individual elements, so their quality deteriorated and they were not reusable. During the archaeological experiments conducted for this work (copper alloys and precious metals) 
it was found that many times the melt had to be replenished with the individual alloy components, added in appropriate proportions. The proportions depended on many factors: first and foremost, the craftsman's experience, practice in combining the metals using the correct proportions, and knowing the right conditions for melting (outdoor area, enclosed area - inside the building). In the case of copper alloys, primarily tin and zinc were added in order to improve the quality of the alloy. Therefore, I do not exclude the use of such procedures by the Wielbark goldsmiths.

In addition, during the final processing of the semi-finished product, there was a lot of waste, such as the metal-filled sprue and venting channels, metal scrap from the filing, grinding and polishing. This represented a significant loss of valuable material. As a result, casting began to be supplemented over time by forging, which, as shown by macroscopic examination of the analyzed artefacts, during the peak period of the Wielbark goldsmithing, equaled and, it would even seem, predominated over casting. This is particularly visible in the case of the metalworking of precious metals such as gold and silver.

\section{FORGING}

Though the Wielbark culture inventory contains no finds which could be indisputably associated with goldsmith workshops, on the basis of traces preserved on the analyzed artefacts it is possible to say that most of the ornaments were made and finished by forging. Forging is one of the oldest and most common techniques of producing ornaments and tools for everyday use, primarily in the smith's workshop. So far, in literature on the subject has prevailed the opinion that a general knowledge of casting provided greater scope for differentiation of forms, and thus that it dominated forging during the Roman period, placing the technique of forging solely in a supplementary role, used to finish objects (Gula 1981, 352). However, this theory is only seemingly true in fact, in the Wielbark culture. This technique supplemented the basic technique of casting from the Early Roman period and was used to finish jewelry, mostly silver and gold, less often of copper alloys. However, starting from phase $\mathrm{B} 2 / \mathrm{C}_{1}$, it even surpassed casting, mainly due to the small loss of raw material which was significant in casting and working casts (cf. more Strobin 2000). It is also worth noting that traces of forging have been observed in practically all categories of ornaments and dress accessories (e.g. brooches, Schlangenkopf and rod bracelets, pendants, buckles, belt-end fittings, etc.) examined in this work. They are also characteristic of iron artefacts or for those in which the base is iron (cf. Fig. 2: 3), which, due to the type of metal used, could not be made by another technique. Wrought artefacts (shaped on dies) are less numerous in the Early Roman period, but dominate in the Late Roman period.

Forging is the method of forming metal by beating an object placed on an iron pad or anvil with a hammer or tamper. There are two basic forging techniques: hot - the workpiece is heated to high temperatures. This was the classic technique of working iron. The second forging technique is cold forging workpiece where pre-cast ingots of, mostly precious 
metals, high alloys of gold, silver and copper, are used in metalwork. During cold forging, the object underwent recrystallization, so it had to be warmed occasionally to change the structure of the metal to a more plastic one and then to continue to work on it. In the Wielbark culture cold forging was used to produce semi-finished/die forgings with regular profiles, usually round or edge-shaped constrictions, grooves, recesses. They were formed in the basic forms of dies, i.e. point chisels and swages, which served to produce a wire, rod or tape with the intended cross-section. Such dies consisted of two parts: the lower socalled bottom fuller with cut profile (anvil variant) embedded in wood - stump and the top called an anvil top, also profiled, which functioned as a hammer. After the two parts were fitted, the intended shape was obtained. This work required two people. One held and slowly shifted the rod while the other hammered the anvil top (Strobin 2000, 232, fig. 1:1-2). However, as demonstrated by experiments, it is possible very simply to cold forge rods, wires and tapes of non-ferrous and precious metals in one-piece dies (also used as an anvil) without using the top anvil, by directly hammering with an anka the equivalent of a die. The anka is a metal cube with hollows of different diameters, used to forge sheet metal into hemispheres, the nodes or empty balls of which served to produce ornaments. In addition, the anka can be used for the final modeling of solid objects, such as the roundness of heads and ectractor rims of Schlagenkopf bracelets (cf. Gradowski 1984, 32; Strobin 2000, 233-234).

In previous studies of tools from goldsmith and forging workshops, objects interpreted as iron anvils and dies are rare. This is primarily due to the condition of the artefacts, often not preserved well, which are regarded as another tool or an unspecified partly processed raw material. A survey of known iron dies from the Bronze Age to the Early Middle Ages is presented by Strobin (2000, 233-234, fig. 3-4). To this list should be added dies found at the Roman legionary camps on the Rhine, in Saalburg, Zugmantel and Feldberg (Dobat 2008, fig. 48; Pietsch 1983).

Based on the traces of forging preserved on the examined artefacts, it can be said that the dies were used primarily to model specific types of ornaments. The earliest dated traces of forging were recorded on the eye brooches of the Prussian series, Almgren group III, where, probably with the aid of a die, a rod was profiled. The rod, coming out from the head of the brooch, was cast together with the plate, and forged on a die of rectangular profile into the tape-like shape of the wire of the spring. Evidence of forging also appears on the bows of brooches, especially in the Almgren groups II, V, VI and VII. An excellent example confirming forging on dies is the pair of brass brooches type A.II.40-41 from mixed finds from the Elbląg cemetery, Elbląg Comm.: Elbląg Pole Nowomiejskie or Elbląg. Moniuszki street, having on the undersides of the brooch plates circular recesses, marks left by the tamper used to hammer the model into the die, pushing the blank into the pattern of the die (Fig. 11: 1-2). Analogous traces were found on a pair of silver Schlangenkopf bracelets from grave no. 107 from the Wielbark cemetery in Pruszcz Gdański, site 7 (Strobin 2000, fig. 10, 13). In the case of brooches of groups VI and VII, the springs were also forged 
and separately the ornamental knobs crowning the ends of the springs and the base of the heads (cf. Strobin 2000, 235-236, fig. 21). Signs of forging were also recorded on the frames and pivots of buckles and hafts of belt-ends. Shaping on dies was used in the production of rod bracelets and most types of Schlangenkopf bracelets discovered at Weklice (cf. Fig. 4: 2-5), which were finished after forging by filing, polishing and burnishing, and then punches of various profiles were used to impress elaborate ornamental compositions.

Engraving is also a technique inseparably connected to forging and is the final step in decorating ready-made products. Patterns are transferred from the die with a sunken relief with a specific engraved shape (of the so-called plunger, stamp or punch). These were certainly iron tools with a carburized, harder work piece, which was tamped by a hammer. The way they were used resulted in rapid tool wear, so in the Wielbark materials in principle we do not have such tools, although elaborate ornamentation of artefacts proves their widespread use in goldsmithing workshops. Numerous punches, evidence of their frequent use, were found in material from the Early Middle Ages (Kočka-Krenz 1993, 29-30). Engraving was used as a decorating technique for all kinds of ornaments (mostly brooches and bracelets) and other dress accessories in the Wielbark culture, with the various groups of motifs occurring with varying frequency in particular chronological phases. Typically, motifs consisted of circle patterns with dots in the middle, triangles, crescents, straight and wavy lines, and imitating beaded wire. Certain gold ornaments found at Weklice were also made by forging, most of all spherical pendants, which were then decorated with filigree and granulation. They were formed on dies with bowl-shaped sections, where the two hemispheres were separately forged and then soldered at the base.

\section{IMPRESSING FOILS}

Directly associated with the technique of forging is impressing (also known as die stamping), that is hammering of smooth or ornamented gold, silver and silver gilded foil with minimum thicknesses of 0.02-0.05 $\mathrm{mm}$. Thin plates of precious metal for making foils were probably beaten on smooth pads, and some researchers believe that primitive rolling and stretching methods were used (cf. Strobin 2007, 675). In the next step, the foils, as needed, were pressed (Ger. Pressblechtechnik) on specially composed, filigree matrix, forming mainly various arrangements of twisted, braided, slanting or herringbone wire patterns and granulation compositions (cf. Figure $2: 1-4 ; 3: 3$ ). Such foils served primarily to decorate brooches. There are many ornamental convergences in the material from Weklice (occurrence of the same ornamental motifs), and consequently also technical similarities, on the foils that decorate different types of brooches, but always coming from the same chronological stadia. The second technique of impressing consists in placing previously beaten smooth foils on a foundation of a thick layer of wax, and then manually etching the intended pattern using a thin stylus. Lead may also have been used instead of wax for this purpose. 


\section{FILIGREE}

It is one of the oldest and most popular and well-known goldsmithing techniques (Duczko 1985, 16-22). It consists of creating ornamental components made from thin gold, silver or copper alloy wires, with a maximum diameter of 2-3 $\mathrm{mm}$. In ancient times the filigree wire, mostly round in section, was produced by three methods. By forging a pre-cast rod, twisting around its own axis a narrow strip of sheet metal and stretching by rolling between wooden boards, or by drawing the wires through drawplates. Theophilus Presbyter mentions such a drawplate in Book III, Chapter 8 (Kobielus 1998, 63). Iron bars with holes of different diameters probably served as drawplates. Basically, finds of such tools from the Barbaricum territories during the period we are interested in are rare. An iron bar from the bog site at Illerup Ådal is interpreted as being a drawplate and simultaneously a matrix for forging rivet heads. This tool is in the shape of an elongated trapezoid, with a circular depression (matrix) at the shorter end and an approximately $2 \mathrm{~mm}$ hole at the longer side, which was probably used for drawing wire (Dobat 2008, 25-26, fig. 3). A miniature drawplate and other miniature goldsmithing tools come from a gold necklace, part of a hoard discovered at Szilágysomlyó (present day Romania) dated to $4 / 5^{\text {th }} \mathrm{c}$. AD (Capelle 1994, 2011, 23-24, fig. 10). A slightly later drawplate was found in the Gepid cemetery at Band, Mureş district, Romania, grave no. 10. The furnishings of this grave comprised, apart from a triangular drawplate with five holes of varying diameters, also a large collection of tools for metalworking (Dobat 2008, fig. 38; Ohlhaver 1939). Whereas, the oldest artefacts interpreted with certainty as drawplates for wires appear no earlier than the Viking period (cf. Duczko 1985, 17, fig. 1-2).

The wires were then used to composed decorative patterns and details. Two kinds of wires were commonly used in Wielbark goldsmithery. The first was a smooth single, double, or even triple thread wire, which was twisted into something resembling a rope, wickerwork or braid pattern, or composed into patterns of different kinds (snail-like, circles, wavy lines, swirls etc.). The second wire was a cut wire (beaded). It was formed by a lateral incision with a special tool (in the shape of a knife) made of an iron rod with a groove engraved on the underside. This cut created a beaded effect. (Duczko 1985, 18; Foltz 1979, 213; Strobin 1998, 127). A knife from the Roman period used for incising wire comes from the bog site at Illerup Ådal, where it was preserved together with its wooden handle (von Carnap Bornheim, Ilkjær 1996a, 379; 1996b, 81; Dobat 2008, 33, fig. 6).

These arrangements of wires were then applied to the ornaments and attached to the substrate with solders. In the analyzed materials from the cemetery at Weklice (cf. Figs. 1-3), filigree was mainly used to decorate brooches, s-shaped buckles, capsule and spherical pendants, as well as Schlangenkopf bracelets, and in small decorative detailing on the ruffs of heads of Schlangenkopf bracelets. In rare cases, incised wires were applied to belt-end fittings made of copper alloy (cf. Natuniewicz-Sekuła and Okulicz-Kozaryn 2011, pl. III:15/2-3; XXXIV:82/3; CXC:434/5-6; CCXXXVIII:3; CCXXXIX:5). 


\section{GRANULATION}

This technique of composing decorative patterns out of small spheres from 0.3 to $3 \mathrm{~mm}$ in diameter, and above, has been known since the middle of the $3^{\text {rd }}$ millennium $\mathrm{BC}$, and was especially popular among the Etruscans (Wolters 1983; Nestler and Formigli 1994). The spheres were usually made of gold and silver alloys. There is no source data to confirm that granulation was made from copper alloys, though in literature on the subject such a claim has been made (Strobin 1998, 127). Today copper alloy granulation is possible with the use of tin paste as solder, as shown by archaeological experiments (cf. more Čáp et al. 2011, 113-115). However, in archaeological material over the course of history such finds are very rare and, in principle, have not been fully researched as far as the technology is concerned. In material from the Roman period I have not come across any such finds. The few technological studies indicate that in these known cases we probably have to do with the so-called pseudogranulation, that an artefact which has been cast with spherical granules. An exception is copper granulation gilded or silver plated (Wolters 1983, 13). It seems that in antiquity this type of ornamentation, due to the physicochemical properties of copper-based chemical solders used at that time, which were mostly used to solder gold and silver filigree and granulation, was technically impossible to control.

Historical sources, as well as archaeological experiments, indicate two methods of making spherical granules. The first was to prepare roughly the same size and weight of metal scraps in the form of small plates or pieces of wire. Next, the scraps of metal are placed in layers in a crucible, with finely ground (powdered) charcoal sprinkled between each layer until the crucible is filled. Then the crucible is placed in a furnace, carefully raising the temperature so that the metal starts to melt but does not turn to liquid. The surface tension (like bubbles produced when cooking water) in the crucible causes the metal pieces to melt into perfect spheres. The charcoal that is not subject to structural changes after being reburnt at high temperatures is a kind of protective insulation preventing the melting of the entire charge in the crucible.

After removing the crucible from the hearth and allowing to cool, its contents are poured onto a clay or other type of organic or metal pad, usually shaped like a bowl. The remaining charcoal powder is then removed by rinsing, blowing or sieving on a very fine mesh sieve. (Čáp et al. 2011, 54-58; Duczko 1985, 22-24). The scraps of molten metal take the form of regular small balls of similar size. Achieving spheres of uniform size depends on the skillful preparation of the metal charge in the crucible, scraps of metal cut into pieces of similar size and weight, and proper arrangement of the metal and charcoal layers. Insufficient protection of all the pieces of metal with charcoal may cause them to fuse together into balls of varying diameters.

The second known method is to melt metal in a crucible and then pour the molten metal through a wooden or clay sieve onto a layer of powdered charcoal or directly into water, mixing the resulting suspension with a brush. The resulting balls are usually large, 
irregular, and of varying sizes. This method is used in modern gold refineries (cf. Hessling 2006, 26-27).

The balls formed in the ways just described were grouped according to size and could then be used for decorating. The segregated spheres were arranged into suitable ornamental patterns on the decorated item, which had been spread with solder using a brush or other implement, and then soldered to the surface. (Čáp et al. 2011; Duczko 1985, 22-24; Wolters 1983, 45). In the examined artefacts, as in Wielbark goldsmithing generally, the balls were applied singly or in concentric arrangements of three or four clusters of granules. They were also set on the circular bases of filigree wire joined into clusters and bunches (Fig. 12: 1-2).

Granulation was very widespread in the Wielbark culture and was used primarily to decorate brooches, fastening capsules of Wellenförmige bracelets, more rarely heads of Schlangenkopf bracelets, as well as small dress accessories such as s-shaped claps or globular, pear-shaped and capsule pendants (cf. Fig. 1-3).

\section{SOLDERING}

A technique inseparably associated with precious metal filigree, granulation and decorating with foils was soldering. It is defined as a method of permanent bonding of metals using a solder which has a lower melting point than that of the metal of the pieces being joined. The soldering process is carried out at a temperature higher than that at which the solder melts but lower than the melting point of the basic metal. As a consequence, the solder melts while the elements connected with it remain in a solid state. During soldering the bonded surface is not melted and permanent bonding occurs due to the phenomenon of shallow diffusion. The solder should also dissolve in itself the metals it is bonding and therefore have similar physicochemical properties. The liquid solder moistens the surfaces of the bonded surfaces, thus penetrating into the resulting porosity of the structure and connecting the basic elements. In order to moisten the soldered elements, the solder must be excited, that is a flux has to be applied together with the solder or just before it is applied. In order to fulfill its functions, the solder must also flow easily and distribute evenly over the places being soldered. It should have the same color as the bonded metals. When working with precious metals, two kinds of solder are used: hard solders - with a high melting point, which can be forged but are difficult to file, suitable for items to be forged or stretched, and soft solders - with low melting point, brittle, difficult to forge but easy to file, for instance when finishing items with filigree and granulation (Gradowski 1984, 95).

\section{SOLDERING OF FOILS}

Starting from the Middle Ages and continuing to this day, metallic solders are most commonly used in the goldsmithing of precious metals. These are mostly silver and gold alloys mixed with copper filings (Gradowski 1984, 95-97; Maryon 1971, 5-40; Wolters 1975; 
1986, 62-63; Zastawniak 1995, 212-221 - where a detailed overview of the types of solder used in the old goldsmithery). Such solders were primarily used to join larger metal parts, especially individual parts of vessels. Solders of this kind were generally ductile and resistant to breaking and otherwise hard. Consequently, the further processing of the vessel which was being forged did not cause damage to its components.

In Wielbark culture, metallic solders are associated with the above mentioned impressed and smooth foils. Using these solders, foils were attached to the substrate. In several of the analyzed cases their chemical composition were determined (cf. Table $4-C D$ ). Analyzes showed that in the case of foils fixed to a substrate made mostly of copper alloys, less often from silver and iron, tin-lead solders were used. The maximum values of the contents elements of solder are: $35.64 \%-80.16 \%$ tin and $6.41 \%-41.37 \%$ lead, with the presence of other elements that have probably been measured from the alloy of the substrate.

The results of these analyzes do not differ significantly from other analyzes of the solder binders for thin foils from the Wielbark culture territory. Similar results were obtained after analyzes of the solders from the cemetery at Kowalewko, Oborniki Comm. (Nosek and Kowalska 2001, 440), and from Pruszcz Gdański, site 7, Pruszcz Gdański Comm. (Strobin 2007, 674). Regarding iron finds decorated with soldered precious metal foils, it is worth emphasizing that the tin forms permanent mechanical and chemical bonds with iron with poor technological properties. The monk Theophilus mentioned about soldering iron only with a solution of copper and tin. He writes primarily about bleaching - the tinning of various iron objects (Book 3, Chapter 92; Kobielus 1998, 160-161). Also, neither gold nor silver form permanent solder bonds with iron due to their physicochemical properties (Gradowski 1984). Therefore, the use of tin solder to join the silver and gilded foils on the iron ornaments, which is observed in a large series of Weklice finds, meaning that this binder was not stable enough, and the foils quickly became destroyed - loosening during use. That why, the addition of lead would probably increase the mechanical properties of such a solder binder.

An excellent example of the use of soldered foil and filigree and granulation on an iron find is the brooch from grave 26B discovered at Weklice (cf. Fig. 2: 3), which at the time of discovery practically fell apart in the hands. It is also amazing example of experiments a Wielbark culture goldsmiths on different kinds of metal raw material. Therefore, it is not a surprising fact regarding the presence of the iron tinning brooches, where the tinning had to imitate silvering. One should suppose that tinning has been used for practical reasons, possibly due to insufficient knowledge of the mechanical and chemical resistance of the soldered foils.

For a preparation of such solder, lead was melted with tin (in the form of filings or scraps), then mixed with natural resin (a type of organic glue) and was applied to the substrate in the form of a paste. The monk Theophilus (Book 3, Chapter 89, Kobielus 1998, 157) mentions fir resin, but it could certainly be other kinds of resinous coniferous and deciduous trees. This resin probably protected the metal surface from oxidation during 
heating. The paste thus prepared was applied to the substrate using intermediate tools. Archaeological sources indicate that at that time soldering tools were used only to apply solder binder to the substrate. One good confirmed example of a soldering tool from the Roman period is the find from the bog deposit at Illerup Ådal on the Jutland peninsula. The tool with a horn handle was made of an iron bar with a copper alloy faceted terminal. On the terminal is a small recess, cut at the end, which, as the analytical studies showed, was stained with tin (von Carnap Bornheim and Ilkjær 1996a, 379; 1996b, 23, 81; Dobat 2008, 29-30, 90; fig. 7). The recess in the terminal was used for placing solder. Before the soldering, the tool was heated and when the terminal of the soldering tool was hot, the melted solder (with a lower melting point than the base of the terminal) flowed and was spread evenly for the soldering of the decorative elements. Probably these kinds of soldering tools were also used for tinning the above described brooches. Subsequently, the foil previously prepared was applied to the substrate and further secured with wire braid before being offset against the substrate, and then allowed to dry and bind. The soldering process itself was based on the very slow and skillful heating of the complete composition, not exceeding the melting point of the solder components - the so-called low temperature technique (up to a maximum of $200-220^{\circ} \mathrm{C}$ ). The melting point of the tin is about $190^{\circ} \mathrm{C}$ and that of lead is about $330^{\circ} \mathrm{C}$, depending on the percentage of the element in the solder whose temperature is variable. At about $60 \%$ to $80 \%$ of the tin content of such solder melts at $160^{\circ} \mathrm{C}$. Exceeding this temperature would aggravate the solder elements (bring them to the boil), and then a reaction with thin foil which could cause damage or even destroy it. In addition, during a careful soldering, the components of solder penetrated the protuberances of the impressed foil, while at the same time stiffening and forming more resistant mechanical damage (cf. more Strobin 2007, 674, 678-679, fig. 5-10).

In the written sources, Theophilus recommends the adhibition of charcoal to the soldering of tin elements (Book 3, Chapter 89; Kobielus 1998, 157-158). It follows that the soldering process itself was carried out in furnaces on charcoal slowly raising the temperature with a blowpipe, either directly or by blowing. The use of blowpipes for soldering was confirmed by Saxo Gramaticus in his relation concerning Vikings goldsmiths. He identifies them as blowers in coals, “... they had smelled of ash from the mouth, and their hands were dirty with charcoal ...” (Strobin 1998, 128).

\section{SOLDERING OF GRANULATION AND FILIGREE}

In contrast to the foil soldering technique, in affixing filigree and granulation in the Wielbark culture, metallic solders were of no use. Objects made with the use of tin-lead solder, due to its density and high solubility, would significantly lose their expressiveness, and would give the impression of being sunk in metal, whereas the effect of granulation and filigree would be just the opposite. Despite this J. Strobin $(2007,675)$ emphasises the popularity of tin soldering by pointing at the presence of these kinds of solders under rings 
made of cut wire in silver and brass fibulae from VI and VII Almgren group; however, he does not refer to any published analyses.

Jewelry objects decorated with filigree and granulation attest, above all, to the use of chemical solders (Table 4 - CD). This method was recreated for the first time in the interwar period for the technique of affixing Etruscan granulation (Gradowski 1984, 95). Its main principle is the use of copper compounds obtained from naturally available minerals. Ancient and medieval sources, i.e. the Leyden papyrus X or the relation of monk Theophilus (Stawicki 1987, 72-75; Kobielus 1998), most often describe soldering gold and silver with the so-called chrysocolla - copper silicate (formula $\left.(\mathrm{Cu}, \mathrm{Al})_{8}\left[(\mathrm{OH})_{12} / \mathrm{Si}_{2} \mathrm{O}_{5}\right)_{4}\right]$ ). The name of the mineral comes from Greek chryzos - gold and kolla - glue. In fact, Theophilus Presbyter describes the soldering of gold filigree elements with especially prepared paste containing metallic copper (Volume 3, chapter 51; cf. Kobielus 1998, 94-100). The soldering was about initiating, under the influence of temperature, a reaction between the metallic copper and the base that fused the affixed elements with the base. Other minerals containing copper used in these solders in Antiquity were: azurite, cuprite, blue stone (common name) i.e. copper sulfate, and the most popular then - malachite, accessible also in Barbaricum.

It should be noted that in Antiquity it was malachite - copper carbonate - that was called chrysocolla. This is how literature presents the meaning of that term in its historical and technological aspect. It was already Pliny (XXXIII 26-29) who wrote what this mineral was for: “... The goldsmiths also employ a chrysocolla of their own, for the purpose of soldering gold; and it is from chrysocolla, they say, that all the other substances which present a similar green, have received their name. This preparation is made from verdigris of Cyprian copper, the urine of a youth who has not arrived at puberty, and portion of nitre. It is then pounded with a pestle of Cyprian copper, in a copper mortar and the name given to the mixture is santerna...” (Pliny, Natural History XXXIII, 29 - translated by Bostock and Riley 1857, 110).

Chemical solder was executed by mixing one of the minerals described above in pulverized form with a natural resin dissolved in water, which was a kind of organic glue, and adding borax - a natural mineral composed of hydrated sodium borate - as flux. The base on which granules or filigree elements were arranged with a fine brush or an intermediary tool had earlier been covered with such a mixture in paste or dense liquid form. Analogically to the foils described above, such a composition was placed in an oven and was slowly, skillfully heated on charcoal in reducing atmosphere. At the first stage of the heating (c. $200^{\circ} \mathrm{C}$ ) copper crystals precipitated and deposited on the base, at the second (c. 250$\left.300^{\circ} \mathrm{C}\right)$ copper oxide was reduced, and at the final $\left(c .300^{\circ} \mathrm{C}\right.$ and higher) metallic copper precipitated, penetrating the surface by diffusion and making it porous (Fig. 13: 2), causing permanent fuse through partial melting of soldered elements (Fig. 13: 1, 3). In relevant literature the temperature limit required to reduce metallic copper from its components has not been discussed until now. It was commonly believed to be $850-900^{\circ} \mathrm{C}$ (Duczko 
1985, 27; Wolters 1983, 57). Whereas, Helena Zoll-Adamikowa, Maria Dekówna and Elżbieta Nosek $(1999,92)$ pointed out that the solder temperature indispensable for metallic copper reduction was $c .1064^{\circ} \mathrm{C}$. It has to be noted that the melting temperature of pure silver is $961^{\circ} \mathrm{C}$, and of pure gold $-1063^{\circ} \mathrm{C}$, thus, heating the solder up to the suggested temperature would result in excessive melting of fused surfaces and, subsequently, damaging the ornament and deliquescing of filigree and granulation. Moreover, it has to be emphasized that, depending on the admixture of precious metal alloy, the melting temperature of the base was probably lower. The temperature indispensable for fusing the solder was most probably lower than that mentioned in the above publications. Experiments with soldering filigree and granulation carried out by measuring the temperature required for metallic copper reduction have demonstrated that its optimal value was $780^{\circ} \mathrm{C}$ (Čáp et al. 2011, 34-35). Above this temperature, the procedure did not bring the desired effect.

Thus the created solders were inconspicuous and invisible macroscopically; they created the so-called bridges which were clearly visible only under an electron microscope (Fig. 14: 1-6). Whereas, the entire composition gave such ornaments expressiveness and threedimensionality.

\section{FIRE GILDING}

One of the better known techniques of Wielbark culture goldsmithery is the gilding of silver foil. According to available sources, fire gilding was used at that time. From the modern times to the present, galvanic gilding is in use, consisting in general of an electrolytic bath of gold. This latter method has replaced fire gilding, mainly due to the harmful health effects of the latter which results from the release of poisonous mercury vapors. Theophilus in his treatise warned that one starting fire gilding cannot be hungry, since mercury vapors are very dangerous for an empty stomach. For this purpose, immediately before gilding, he recommended the consumption of common barberry, pepper, garlic and wine. This source informs us also that copper alloy objects were also gilded by the same technique, but such finds in Wielbark culture until now have not been recorded.

The fire gilding method is already described by "Theban Papyri”, especially Leyden papyrus X (Stawicki 1987, 62-63). Overall, it was based on the preparation of an amalgam of gold and mercury (in a ratio of c. 1 part of gold and 8 parts of mercury). Similarly, but with the addition of salt, argol and water preparation of such amalgam can be found in Theo-philus (Book 3, Chapter 38; Kobielus 1998, 85-86). The ingredients were mixed while hot and it should be noted that the preparation of this amalgam requires a lot of experience, precaution and skill, which is clearly emphasized by written sources (cf. Gradowski 1984, 68). This procedure proved to be very difficult to control even for experienced craftsmen. Because of the poisonous effect of mercury vapors that resulted in mysterious deaths, the ability to master and control this technique placed contemporary goldsmiths at 
the higher top of the social hierarchy. Difficulties began when amalgam was applied to the surface of non-precious metal, such as copper alloys. Gold amalgam well moisturizes precious metal surfaces and poorly surfaces non-precious metals. This may lead to significant problems with adhesion of a thin layer of gold to the substrate. This was avoided by precoating the surface to be gilded with a thin layer of mercury or silver. This layer was obtained by means of dynamically rubbing of the object, for example with a brass brush, moistened in solution of mercury or silver. After priming the "bronze" surface with a mercury or silver layer, it was necessary to proceed as soon as possible to apply the amalgam so that the gilding surface was not passivated. In the case of precious metals, the surface of the object before gilding was thoroughly cleaned, most often under the influence of temperature, removing surface fats. It was then etched in acid, heated in a charcoal furnace and then the spreading with a brush (according to Theophilus by means of a hare paw) of an amalgam on the surface of the gilded object. As a result of heating, the mercury oxidized, leaving the gilding on a silver substrate. If it were necessary to obtain a thicker layer of gilding, the whole action had to be repeated. After cooling, the object could be subjected to additional treatments which improved the shine and, for this purpose, the object was rubbed with wax and borax. In addition, the surface was wiped with a brush soaked in a solution of mallow root, and in the final stage of processing, polished in a solution with vinegar to obtain an appropriate gloss (Duczko 1985, 29; Gradowski 1984, 68).

\section{ORIGIN AND ACQUISITION OF RAW MATERIAL}

Considering the total lack of discoveries of outcrops or mines of colored metallic ores, and archaeologically attested traces of the acquisition of metallic elements directly from ores on the Wielbark culture area as well as other cultural units of the Roman Period from the territory of Poland, raw material for production of ornaments must have been imported; most likely from the Roman Empire and its provinces. The significant number of objects made of precious metals or copper alloys indicates quite a large influx of production materials. Relevant literature is abundant and the main conclusion is that remelted coins or scrap-metal from damaged vessels imported from the Roman Empire and its provinces were used for the production of ornaments in the Roman Period (cf. i.a. Bezzenberger 1904, 18; Wielowiejski 1960, 52).

Utility functions of Roman imports, above all the coins, among barbaric people still raise a lot of controversy. In most cases, depending on the quantity and intensity of the import of coins in particular periods and on various territories, the function is considered twofold: raw material for remelting, and money, including currency of precious metals, in internal exchange (cf. i.a. Bursche 1983, 76-78; Kunisz 1969, 137; Wielowiejski 1960, 52). Refraining from the total negation of the theory of the local remelting of coins to obtain precious metals for further production, we should consider their percentage content in these coins. The content of precious metals, first of all silver, in denarii appearing in con- 
siderable numbers in the Wielbark culture changed depending on political and economic situation of the Roman Empire and reforms carried out by its rulers. The percentage of silver was greatest in the times of Nero, with c. 92\%. In the times of Antoninus Pius and Marcus Aurelius it was c. $76 \%$ and during the reign of Septimius Severus it was only c. $46 \%$. The latter is related to the reform of $194 \mathrm{AD}$ concerning the reduction of silver content (Bursche 1988, 39; Gitler and Ponting 2003, 31; Wielowiejski 1969, 3). However, these percentages are contradicted by results of the physical metallurgy analyses presented below. They clearly show that from the very appearance of first solid silver and golden ornaments - in the early stages of the B2 phase - high-quality ore was used for production, with the fineness of silver oscillating between 900-980 for gold and 920-980 for silver. Another premise against the discussed concept is the lack of any data that would confirm the existence of precious metal refining skills among the barbarians. Refining, at that time done with the use of concentrated solutions of acids - e.g. aqua regia for gold, sulphuric and nitric acids for silver - was indispensable for improving the quality or obtaining metal from ores; however, it required proper technological treatment (Zastawniak 1995, 134140). Traces of silver refining are well attested, e.g. in Roman Xanten (Rehren 2003, 211213). As mentioned before, melting together objects of different basic metallic elements content results in the significantly lower quality of raw material. Metal evaporates during smelting and loses its value. It has to be completed with proportionally added alloy components, which was confirmed by experiments carried out for the purposes of the hereby study during which fragments of silver objects of a different fineness were melted together. Unfortunately, because of its heterogeneity, the cast made of such alloy was fragile and porous in section with visible bubbles of air. It cracked during treatment and was susceptible to damage which made further shaping impossible. Considering the huge practical skills of goldsmiths in the Roman Period, it seems probable that accessible metals were carefully selected for quality. Older, better quality coins used for the further production of local ornaments were most likely also selected. It was already Tacitus who wrote that the Germanic people preferred old coins and long-known serrati and bigati (cf. P. Cornelius Tacitus, Germania, chapter 5, translation by Płóciennik 2008, 67; cf. also Wielowiejski 1969, 5).

Considering the use of the best quality precious metals in local products, it cannot be excluded that high quality pure gold and silver bars may have been imported to the Wielbark culture territories. Such finds, bearing stamps, are well attested in the former Roman Empire, both as single finds and hoards. The latter are dated mainly to $3^{\text {rd }}$ and $4^{\text {th }} \mathrm{c}$. AD. They are also discovered by limes camps where trade exchange with barbarians was the most intensive (cf. i.a. Iliescu 1965; Willers 1898). Besides metals, also mercury - obviously in a liquid state - must have been imported in the Roman Period to the present territory of Poland. It was indispensable for the production of gold amalgam in the process of fire gilding. Mercury was obtained mostly from lead ores (cinnabar). The exploited deposits from that time are well attested on the territory of Spain. 
The provenance of raw material for the local production of copper alloy objects needs to be discussed separately. Most of them, which is confirmed by analyses, are made of brass. Therefore, the concept of use of scrap-metal from vessels for the production of ornaments is controversial but cannot be excluded. To my knowledge, the prevailing number of analyses of the composition of Roman vessels indicates that, depending on the workshop, time and place of manufacture, varied raw material groups were used; they were mostly tin and tin-lead bronzes of different proportions of alloy components. Aside from rare exceptions (cf. Natuniewicz-Sekuła 2010), Roman brass vessels do not exist. It is known, however, that brass in the form of scrap-metal was added by the Romans as an alloy component during vessel production to increase their forgeability and machining properties, which is indicated by small amount of zinc in vessel analyses (Niewęgłowski 1991, 287-292).

Despite the difficulties with obtaining metallic zinc, the Romans were able to obtain brass. Remains of a large-scale production are well attested, e.g. in Roman Gallia and Germania Interior (Rehren 2003, 209-210). Physical metallurgy analyses indicate that brass was known already among the Celts and it was used, among others, to make fibulae. Research by Maréchal (1961) has proven that during the first two centuries of our era the content of zinc in copper alloys decreased systematically, whereas the content of lead and tin increased. Based on these findings, Niewęgłowski $(1986,320)$ thinks that the mass production of brass was reborn only after the breaking of the limes, when Romans settled in Gallia.

In the brass produced in the Roman Empire, the content of zinc rarely exceeds 2-25\% (Picon et al. 1966, 191), and is never higher than 28\% (Maréchal 1984, 21). As the research by E. R. Caley'a $(1955,1964)$ has demonstrated, it was the main alloy used for production of sestertii and dupondii (cf. also Riederer 1984). From the times of the first emperors until Vespasian they were made of brass with considerable content of zinc, sometimes exceeding 20\%. Later, its content decreases, and after the reign of Antoninus Pius it undergoes a further abrupt decrease (Condamin and Boucher 1973, 168; Riederer 1987, 119). Not only were coins made of brass but also decorative parts of horse tack, small cultic figurines, and, supposedly, thin plates adorning wreaths for actors (Niewęgłowski 1986, 305).

Maréchal $(1984,22)$ divided Roman brass into three groups based on zinc content: group 1 - below 4\%; group 2 - between 4 and $20 \%$, where the highest proportion is c. $13 \%$; group 3 - between 22 and $28 \%$ without other alloy additions. In the analyzed objects, the zinc content fits within groups 1 and 2. However, I must emphasize that, just like in case of precious metals, zinc evaporates during remelting of brass so each smelting results in lowering its content in obtained alloy. Interestingly, the lower content of zinc in brass is characteristic for the analyzed objects from the younger Roman Period, in contrast to objects from early Roman Period. Therefore, we can assume that previously selected older coins were remelted more often due to the lack of influx of better quality material for re-use. On the other hand, we do not have any source data confirming trade exchange in copper alloy bars, although it should not be excluded. A find that can confirm this supposition is a "bronze" plate from Ukraine (Zarichanka, Chemerovsty Comm.), not yet chemically ana- 
lyzed, bearing a Roman inscription of a military diploma - a guarantee of special privileges for a deserving legionnaire from an auxiliary unit. On the basis of accompanying finds, including denarii from $2^{\text {nd }}$ half of $2^{\text {nd }} \mathrm{c}$. $\mathrm{AD}$, this object is dated to the beginning of $3^{\text {rd }} \mathrm{c} . \mathrm{AD}$ and is associated with the settlement of the Wielbark culture, and - as J. Kolendo suggests - it could have been used as material for re-use (Kolendo 2010, 317-318).

An utterly surprising find from Augusta Vindelicum (Augsburg), the capital of the Raetia province, is a discovery in a metallurgic workshop of a deposit composed of over two hundred "bronze" - but made most probably of brass - eye fibulae of the Prussian series, including springs and needles forged from metal bands, which is characteristic for this type (Bakker 1985, 101-104; 2003, 262, fig. 3). This find is dated to the end of $1^{\text {st }} \mathrm{c}$. $\mathrm{AD}$, which is generally in accordance with the first appearance of these fibulae in barbarian territories, most numerous in former East Prussia, especially at the mouth of the Vistula from where they originate. The very fact of the discovery of these fibulae in a Roman environment is interpreted as the remains of a Germanic workshop functioning in Augsburg. On the other hand, which I favor more considering the original center of provenance of these fibulae, we may be dealing with the export from Germanic territories of raw material which was then hardly accessible for the Romans and may have been used as scrap-metal for further production. Regarding the location of the province on the border with Germania, this theory seems quite probable.

Full explanation of the issue of the provenance and acquisition of raw material remains within the sphere of speculation. It should be noted, however, that in the Wielbark culture coins are unearthed on burial grounds in the context of ornaments and grave goods or hoards (Ciołek 2007, 291, map 3). Analysis of settlement finds, above all coins bearing traces of treatment suggesting the presence of goldsmith workshops, would be the most helpful in explaining this issue. Such examples are silver, gold, and copper-alloy coins from the socalled "caster" hoard from Frombork, Braniewo Comm., some of which were cut and broken. The hoard contained 24 denarii, a solidus of Theodosius II, a sestertius of Antoninus Pius for Faustina I, and a halved assarius (Ciołek 2007, 47-49, No 67). Analogous traces of splitting or notches were discovered in a series of discoveries of denarii from the Przeworsk culture settlement at Jakuszowice, Kazimierza Wielka Comm., and these coins are interpreted as material for further processing in metallurgic workshops (Bursche et al. 2000, 111-112).

Roman denominations known from the Wielbark culture territories are characterized by a smaller proportion of copper alloy coins as compared to precious metal coins (cf. more Zapolska 2012). Most of them were not chemically analyzed, which is why, without excluding the re-use of coins or even destroyed vessels for the further production of Wielbark ornaments, I very much support the theory of the import of pure metal bars. In the case of copper alloys, mostly brass imitating the colour of gold, it may even have been the import of Roman utility and cult brass objects (votive figurines, parts of horse tack, bells, military diplomas etc.), which in the Wielbark culture territories did not have the function of grave goods. 


\section{CONCLUSIONS}

The main technological aspects of Wielbark culture goldsmithery described above can be boldly classified as the most interesting trends in manufacturing ornaments and metal outfit parts in European Barbaricum. Its uniqueness has been determined by the combination of a variety of techniques and technologies, both derived from the local tradition as well as undoubtedly being the creative impulse of the Mediterranean world. Thanks to the skill and creativity of contemporary goldsmiths, original jewelry was created, in which the elements of Roman style and local designs were professionally combined. The changing fashion, social transformation and trans-regional contacts influenced the work of Gothic goldsmiths, which became a reflection of these phenomena. The goldsmith's workshop constantly evolved, using new and modifying already known technologies. Therefore, jewelry became one of the main determinants of cultural identification of discoveries connected with the presence of the Goths in the present day territory of Poland. In addition, it should be noted that the Wielbark Culture goldsmith's workshop is characterized by dynamic development of design and technology, and this change would have been accompanied with transformation of the workshop itself.

It most likely did not occur simultaneously in all workshops throughout the Wielbark Culture.

Presumably, there were leading workshops forming style in fashion, concentrated at centers of power, and smaller workshops assimilating and incorporating new techniques and technologies. It is not always possible to precisely identify the recipients of manufactured jewelry in terms of their social position. Assuming that luxury items were created for the aristocracy, it may be supposed that it was in the aristocratic environment that fashion which designated trends in craft was evolving. Furthermore, nor do we know whether (and if so, to what extent) there were any social norms concerning the wearing of jewelry, both luxurious items and more common ones. It is known, however, that precious jewelry was a sign of prestige and power for the Germans (cf. more Bursche 1998), and this in fact is reflected in the distribution of jewelry inter-regionally and over-regionally. The goldsmith's workshop of the Wielbark Culture incorporated a broad spectrum of available metal alloys and the most advanced techniques and technologies.

As rightly pointed out by Michał Gradowski $(1984,8)$ in his book "Past Goldsmiths", leading goldsmiths from classical antiquity reached a level of mastery that modern ones are still attempting to attain.

\section{Acknowledgements}

The article was prepared under the projects: Scientific Research Committee no. NN 109087633 and National Science Center no. 2013/11/D/HS3/02473. 


\section{Written sources}

Edda

Edda Poetycka, Załuska-Strömberg A. 1986. Translation from Old Icelandic and elaboration. Wroclaw: Zakład Narodowy im. Ossolińskich.

Leyden Papyrus X, Stockholm Papyrus

Stawicki S. and Wojtczak J. 1987. Translation, 220-275. Wrocław: Zakład Narodowy im. Ossolińskich. Pliny the Elder

The Natural History, translation Bostock J. and Riley H. T. 1857. London: Enry G. Bohn, York Street, Convent Garden.

Publius Cornelius Tacitus

Germania, translation Płóciennik T. 2008. Introduction and commentary J. Kolendo (= Fontes Historiae Antiquae 10). Poznań: Wydawnictwo Naukowe UAM.

Theophilus Presbyter

Diversarum Atrium Schedule. Średniowieczny zbiór przepisów o sztukach rozmaitych, Translation from the Latin language and elaboration Kobielus S. 1998. Kraków: Tyniec, Wydawnictwo Benedyktynów.

\section{References}

Almgren O. 1923. Studien über nordeuropäische Fibelformen der ersten nachchristlichen Jahrhunderte mit Berücksichtigung der provinzialrömischen und südrussischen Formen (= Mannus-Bibliothek 32). Leipzig: Verlag von Curt Kabitzsch.

Andrzejowski J. 1998. Nadkole 2. A Cemetery of the Przeworsk Culture in Eastern Poland (= Monumenta Archaeologica Barbarica 5). Kraków: Instytut Archeologii i Etnologii PAN - Państwowe Muzeum Archeologiczne w Warszawie.

Bakker L. 1985. Ausgrabungen an der Kornhausgasse in der Provinzhauptstadt Augusta Vindelicum-Augsburg. Das archäologische Jahr in Bayern. Stuttgart: Konrad Theiss Verlag, 101-104.

Bakker L. 2003. Zeugnisse des Handels. Neues aus rätischen Hauptstadt Aelia Augusta (Augsburg). In W. Menghin and D. Planck, Menschen. Zeiten. Räume. Archäologie in Deutschland. Stuttgart: Theiss, 262-264.

Bayley J. 1995. Spoon and vessels moulds from Castelford, Yorkshire. In S. T. A. M. Mols, A. M. Gerhartl-Witteveen, H. Kars, A. Koster, W. J. T. H. Peters and W. J. H. Willems (eds.), Acta of the $12^{\text {th }}$ international congress on ancient bronzes Nijmegen 1992. Nijmegen: Provincial Museum G. M. Kam, 105-111.

Bayley J. and Butcher S. 1981. Variations in alloy compositions of Roman brooches. Revue d'Archéométrie 6, supplement, 29-36.

Bayley J. and Butcher S. 1989. Romano-British plate brooches: their composition and decoration. Jewellery Studies 3, 25-32.

Bayley J. and Butcher S. 1995. The Compositions of Roman brooches found in Britain. In S. T. A. M. Mols, A. M. Gerhartl-Witteveen, H. Kars, A. Koster, W. J. T. H. Peters and W. J. H. Willems 
(eds), Acta of the $12^{\text {th }}$ international congress on ancient bronzes Nijmegen 1992. Nijmegen: Provincial Museum G. M. Kam, 113-119.

Bayley J. and Butcher S. 2004. Roman Brooches in Britain: A Technological and Typological Study based on the Richborough Collection. London: The Society of Antiquaries of London.

Beckmann B. 1966. Studien über Metallnadeln der römischen Kaiserzeit im freien Germanien. Saalburg Jahrbuch 23, 5-100.

Beckmann Ch. 1969. Metallfingerringe der römischen Kaiserzeit im freien Germanien. Saalburg Jahrbuch 26, 5-106.

Bezzenberger A. 1904. Analysen vorgeschichtlicher Bronzen Ostpreussens. Königsberg: Verlag von Gräfe \& Unzer.

Bochnak T. 1997. Metalurgia metali nieżelaznych na terenie osady z mtodszego okresu przedrzymskiego i okresu wplywów rzymskich w Jakuszowicach, gm. Kazimierza Wielka, st. 2. Kraków (unpublished MA Thesis in the archive of the Institute of Archaeology Jagiellonian University).

Bochnak T. 2000. Tygle odlewnicze znalezione na terenie osady w Jakuszowicach, gm. Kazimierza Wielka, woj. świętokrzyskie. Uwagi na temat metalurgii metali nieżelaznych. In R. Madyda-Legutko and T. Bochnak (eds.), Superiores Barbari. Księga ku czci Profesora Kazimierza Godtowskiego. Kraków: Instytut Archeologii Uniwersytetu Jagiellońskiego, 81-100.

den Boestred M. H. P. and Hoekstra E. 1965. Spectrochemical analyses of Roman bronze vessels. Oudheidkundige Medelingen uit het Rijksmuseum van Oudheden te Leiden, 46/12, 100127.

Bursche A. 1983. Moneta i kruszec w kulturze wielbarskiej w okresie późnorzymskim. Przegląd Archeologiczny 31, 82-93.

Bursche A. 1988. Kontakty Cesarstwa rzymskiego z ludnością kultury wielbarskiej w III i IV w. w świetle źródeł numizmatycznych. In J. Gurba and A. Kokowski (eds), Kultura wielbarska $w$ młodszym okresie rzymskim 1. Lublin: Uniwersytet Marii Curie-Skłodowskiej w Lublinie, Katedra Archeologii, 37-50.

Bursche A. 1998. Złote medaliony rzymskie $w$ Barbaricum. Symbolika prestiżu i wladzy spoteczeństw barbarzyńskich u schyłku starożytności (= Światowit Supplement Series A: Antiquity 2). Warszawa: Instytut Archeologii Uniwersytetu Warszawskiego.

Bursche A., Kaczanowski P. and Rodzińska-Nowak J. 2000. Monety rzymskie z Jakuszowic. In R. Madyda-Legutko and T. Bochnak (eds.), Superiores Barbari. Księga ku czci Profesora Kazimierza Godłowskiego. Kraków: Instytut Archeologii Uniwersytetu Jagiellońskiego, 101-130.

Bursche A. and Okulicz-Kozaryn J. 1999. Groby z monetami rzymskimi na cmentarzysku kultury wielbarskiej w Weklicach koło Elbląga. In J. Andrzejowski (ed.), Comhlan. Studia z archeologii okresu przedrzymskiego i rzymskiego w Europie Środkowej dedykowane Teresie Dąbrowskiej w 65. rocznicę urodzin. Warszawa: Fundacja Przyjaciół Instytutu Archeologii Uniwersytetu Warszawskiego, 141-163.

Caley E. R. 1955. On the existence of chronological variations in the composition of Roman brass. The Ohio Journal of Science 55, 137-140. 
Caley E. R 1964. Orichalcum and Related Ancient Alloys. Origin, Composition an Manufacture with Special Reference to the Coinage of the Roman Empire (= Numismatic Notes and Monographs 151). New York: The American Numismatic Society.

Capelle T. 1994. Die Miniaturenkette von Szilágysomlyó (Şimleul Silvaniei) (= Universitätsforschungen zur prähistorischen Archäologie 22). Bonn: Habelt Verlag.

Capelle T. 2011. An insight into goldsmith's workshop. In A. Pesch and R. Blankenfeldt (eds.), Goldsmith Mysteries. Archaeological, pictorial and documentary evidence from the $1^{\text {st }}$ millennium $A D$ in northern Europe. Schleswig: Wachholtz Verlag, 17-27.

von Carnap-Bornheim C. and Ilkjær J. 1996a. Illerup Ådal 5. Die Prachtausrüstungen. Textband. Aarhus: Jysk Arkæologisk Selskab - Mosegård Museum.

von Carnap-Bornheim C. and Ilkjær J. 1996b. Illerup Ådal 6. Die Prachtausrüstungen. Katalog, Fundlisten und Literatur. Aarhus: Jysk Arkæologisk Selskab - Mosegård Museum.

von Carnap-Bornheim C. and Ilkjær J. 1996c. Illerup Ådal 7. Die Prachtausrüstungen. Tafelband. Aarhus: Jysk Arkæologisk Selskab - Mosegård Museum.

Chardron-Piacult P. and Pernot M. 1999. Un quartier antigue d'artisanat métallurgique à Autun (Saône-et Loire): Le site du Lycée militaire (= Documents d'archéologie française 76). Paris: Éditions de la Maison des sciences de l'homme.

Ciołek R. 2007. Die Fundmünzen der Römischen Zeit in Polen. Pommern (= Collection Moneta 67). Wetteren-Warschau: Moneta - Institut für Archäologie der Warschauer Universität.

Condamin J. and Boucher S. 1973. Recherches techniques sur les bronzes de Gaule romaine IV. Gallia 31(1), 157-183.

Czarnecka K. 2007. Oblin. Ein Gräberfeld der Przeworsk-Kultur in Südmasowien (= Monumenta Archaeologica Barbarica 13). Warszawa: Państwowe Muzeum Archeologiczne w Warszawie - Fundacja Monumenta Archaeologica Barbarica.

Czerni S. (ed.). 1967. Encyklopedyczny stownik techniczny. Warszawa: Wydawnictwa NaukowoTechniczne.

Čáp P., Macháček J. and Špaček J. 2011. Tajemství výrobu velkomoravského šperku. Archeologický experiment. Praha: Koniasch Latin Press.

Dąbrowska T. 1988. Wczesne fazy kultury przeworskiej. Chronologia - zasięg - powiązania. Warszawa: Państwowe Muzeum Archeologiczne.

Dąbrowska T. 1995. Późne odmiany fibul silnie profilowanych w Polsce. Wiadomości Archeologiczne 53(1), 3-34.

Dąbrowska T. 1997. Kamieńczyk. Ein Gräberfeld der Przeworsk-Kultur in Ostmasowien (= Monumenta Archaeologica Barbarica 3). Kraków: Instytut Archeologii i Etnologii Polskiej Akademii Nauk - Państwowe Muzeum Archeologiczne w Warszawie.

Dąbrowski K. and Śląska I. 1956. Łyżka odlewnicza ze wsi Piwonice, pow. Kalisz. Wiadomości Archeologiczne 23(2), 213-215.

Dobat A. S. 2008. Werkzeuge aus kaiserzeitlischen Heeresausrüstungsopfern. Mit besonderer Berücksichtigung der Fundplätze Illerup Ådal und Vimose. Århus: Jysk Arkæologisk Selskab - Mosegård Museum. 
Dobrzańska H. 1990. Osada z późnego okresu rzymskiego w Igotomi, woj. krakowskie. Część 2. Wrocław-Kraków: Zakład Narodowy im. Ossolińskich.

Dobrzański L. 1993. Metaloznawstwo i obróbka cieplna stopów metali. Gliwice: Wydawnictwo Politechniki Śląskiej.

Domergue C. 2008. Les mines antiques. La production des métaux aux époques grecque et romaine. Paris: Picard.

Drescher H. 1958. Der Überfangguss: ein Beitrag zur vorgeschichtlichen Metalltechnik. Mainz: Verlag des Römisch-Germanischen Zentralmuseums.

Drescher H. 1973. Der Guss von Kleingerät, dargestellt an Funden aus provincialrömischen Werkstätten. Early Medieval Studies 6, 48-62.

Duczko W. 1985. The Filigree and Granulation work of the Viking Period. An Analysis of the Material from Bjorko (= Birka 5). Stockholm: Kungl. Vitterhets Historie och Antikvitets Akademien Almqvist and Wiksell.

Eggers H. J. 1951. Der römische Import im Freien Germanien. Hamburg: Hamburgisches Museum für Völkerkunde und Vorgeschichte.

Elschek K. 2002. Ein Hortfund von römischen Bronzegefäßbruchstücken, neue Grab- und Siedlungsfunde aus Zohor (Westslowakei). In K. Kuzmová, K. Pieta and K. Rajtár (eds.), Zwischen Rom und dem Barbaricum. Festschrift für Titus Kolník zum 7o. Geburtstag. Nitra: Archeologický Ustav SAV, 245-260.

Foltz E. 1979. Einige Beobachtungen zu antiken Gold- und Silberschmiedetechniken. Archäologisches Korrespondenzblatt 9, 213-222.

Gan P. 2015. Charakterystyka chemiczna zabytków z cmentarzyska w Czarnówku - analizy wprowadzające. In J. Andrzejowski (ed.), Czarnówko, stan. 5. Cmentarzyska z późnej starożytności na Pomorzu. Część 1 (= Monumenta Archaeologica Barbarica, Series Gemina 5). Lębork Warszawa: Muzeum w Lęborku - Fundacja Monumenta Archaeologica Barbarica, 175-214.

Ginalski J. 1991. Ostrogi kabłąkowe kultury przeworskiej. Klasyfikacja typologiczna. Przegląd Archeologiczny 38, 53-84.

Gitler H. and Ponting M. 2003. The Silver Coinage of Septimus Severus and his family (193-211 AD). A Study of the Chemical Composition of the Roman and Eastern Issues. Milano: Ennerre.

Glazer W. and Okulicz J. 1955. Wyniki metaloznawczych i technologicznych analiz ozdób metalowych z cmentarzyska w miejscowości Netta, pow. Augustów. Wiadomości Archeologiczne 22, 304-310.

Godłowski K. 1970. The Chronology of the Late Roman and Early Migration Periods in Central Europe (= Zeszyty Naukowe Uniwersytetu Jagiellońskiego, Prace Archeologiczne 11). Kraków: Uniwersytet Jagielloński.

Godłowski K. 1972. Fromborski skarb z okresu wędrówek ludów. Komentarze Fromborskie 4, 57-69.

Godłowski K. 1977. Materiały do poznania kultury przeworskiej na Górnym Śląsku. Materiały Starożytne i Wczesnośredniowieczne 4, 7-237.

Grabarczyk T. 1983. Metalowe rzemiosto artystyczne na Pomorzu w okresie rzymskim (= Prace Komisji Archeologicznej 9). Wrocław-Gdańsk: Zakład Narodowy im. Ossolińskich - Gdańskie Towarzystwo Naukowe. Wydział Nauk Społecznych i Humanistycznych. 
Gradowski M. 1984. Dawne złotnictwo. Technika i terminologia. Warszawa: Państwowe Wydawnictwo Naukowe.

Grzymkowski A. 1986. Wstępne wyniki badań na birytualnym cmentarzysku ciałopalnym i szkieletowym w Modle, gm. Wiśniewo, woj. Ciechanów. Sprawozdania Archeologiczne 38, 223-258.

Gula K. 1981. Metalurgia. In J. Wielowiejski (ed.), Prahistoria ziem polskich 5. Wrocław: Zakład Narodowy im. Ossolińskich - Wydawnictwo Polskiej Akademii Nauk, 335-355.

Hahuła K. and Wołągiewicz R. 2001. Grzybnica. Ein Gräberfeld mit Steinkreisen der Wielbark-Kultur in Pommern (= Monumenta Archaeologica Barbarica 8). Warszawa-Koszalin: Muzeum w Koszalinie - Fundacja Przyjaciół Instytutu Archeologii Uniwersytetu Warszawskiego Państwowe Muzeum Archeologiczne w Warszawie.

Hammer P. and Voss (Voß) H-U. 1997. Metallkundliche Untersuchungen an römischen und germanischen Funden des Elbegebietes (= British Archaeological Report, International Series 678). Oxford: Archaeopress.

Hammer P. and Voss (Voß) H-U 2011. Aussagen der elektrischen Leitfähigkeit zu Legierung und Herstellung von Fibeln und Gefäßteilen. Bericht der Römisch-Germanischen Kommission 90 (2009), 200-229.

Hensel Z. 1998. Badania materiałoznawcze zabytków metalowych z cmentarzyska kultury wielbarskiej w Świętym Gaju - stopy miedzi. In P. Urbańczyk (ed.), Adalbertus. Wyniki programu badań interdyscyplinarnych 1. Warszawa: Instytut Archeologii i Etnologii PAN, 141-147.

Hessling M. 2006. Edelmetallgewinnung bei der Norddeutschen Affinerie Ag. In R. A. Weiss and W. Marnette (eds), Frühes Gold aus Norddeutschland. Eines Ausstellung des Helms-Museums Hamburg. Hamburg: Helms-Museum, 26-28.

Hull M. R. and Hawkes C. F. C. 1987. Corpus of Ancient Brooches in Britain: pre-Roman Bow Brooches (= British Archaeological Report 168). Oxford: Archaeopress.

Iliescu O. 1965. Nouvelles informations relatives aux lingots Romains d'or, trouvés en Transylvanie. Revue des études sud-est européennes 3(1-2), 269-281.

Jamka R. 1963. Materiały kultury przeworskiej z Leonowa, stanowisko II, pow. Łódź (= Zeszyty Naukowe Uniwersytetu Jagiellońskiego 73. Prace Archeologiczne 5). Kraków: Uniwersytet Jagielloński, 59-75.

Jaskanis J. 2005. Krupice. Ein Gräberfeld der Przeworsk- und Wielbark-Kultur in Ostpolen (= Monumenta Archaeologica Barbarica 10). Warszawa: Fundacja Przyjaciół Instytutu Archeologii Uniwersytetu Warszawskiego - Stowarzyszenie Archeologów Polskich Oddział w Warszawie Państwowe Muzeum Archeologiczne w Warszawie.

Jobst W. 1975. Die römischen Fibeln aus Lauriacum (= Forschungen in Lauriacum 10). Linz: Oberösterreichische Landesmuseum.

Jonakowski M. 2001. Grób szkieletowy kultury wielbarskiej z cmentarzyska w Lubieszewie, pow. Nowy Dwór Gdański, stanowisko 2. Wiadomości Archeologiczne 54, 185-188.

Karczewski M. 2011. Archeologia środowiska zachodniobattyjskiego kręgu kulturowego na pojezierzach. Poznań-Białystok: Bogucki Wydawnictwo Naukowe - Instytut Historii i Nauk Politycznych Uniwersytetu w Białymstoku. 
Kasprzycka M. 1999. Tto paleogeograficzne osadnictwa Żulaw Elbląskich w pierwszy tysiacleciu naszej ery. Warszawa: Instytut Archeologii i Etnologii Polskiej Akademii Nauk.

Kmieciński J. 1968. Odry, cmentarzysko kurhanowe z okresu rzymskiego $w$ powiecie chojnickim (= Acta Archaeologia Lodziensia 15). Łódź-Wrocław: Łódzkie Towarzystwo Naukowe. Wydział II Nauk Historycznych i Społecznych - Zakład Narodowy im. Ossolińskich.

Knobloch M. 1977. Zlotnictwo. Warszawa: Wydawnictwa Naukowo-Techniczne.

Kolendo J. 2010. Roman Bronze on the territory of Barbaricum. On a Find of a Military Diploma from Ukraine. In A. Urbaniak, R. Prochowicz, I. Jakubczyk, M. Levada and J. Schuster (eds.), Terra Barbarica. Studia ofiarowane Magdalenie Mączyńskiej w 65. rocznicę urodzin (= Monumenta Archaeologica Barbarica, Series Gemina 2). Łódź-Warszawa: Instytut Archeologii Uniwersytetu Łódzkiego - Fundacja Uniwersytetu Łódzkiego - Fundacja Monumenta Archaeologica Barbarica - Państwowe Muzeum Archeologiczne w Warszawie, 315-320.

Kokowski A. 1981. Pochówki kowali w Europie od IV w. p.n.e. do VI w. n.e. Archeologia Polski 26(1), 191-218.

Kokowski A. 1991. Grób wojownika kultury przeworskiej z Orońska w woj. radomskim (= Acta Universitatis Lodziensis, Folia Archaeologica 12). Łódź: Wydawnictwo Uniwersytetu Łódzkiego, 105-133.

Kočka-Krenz H. 1983. Złotnictwo skandynawskie IX-XI wieku. Poznań: Uniwersytet im. Adama Mickiewicza w Poznaniu.

Kontny B. and Natuniewicz-Sekuła M. 2010 „Jeździec bez głowy” et alii, czyli znaleziska ostróg z cmentarzyska kultury wielbarskiej w Weklicach. In A. Urbaniak, R. Prochowicz, I. Jakubczyk, M. Levada and J. Schuster (eds.), Terra Barbarica. Studia ofiarowane Magdalenie Maczyńskiej $w$ 65. rocznicę urodzin (= Monumenta Archaeologica Barbarica, Series Gemina 2). Łódź-Warszawa: Instytut Archeologii Uniwersytetu Łódzkiego - Fundacja Uniwersytetu Łódzkiego - Fundacja Monumenta Archaeologica Barbarica - Państwowe Muzeum Archeologiczne w Warszawie, 333-345.

Krawczuk A. 1956. Wybór źródet pisanych do dziejów górnictwa i metalurgii świata antycznego. Część I - cynk i mosiądz (= Prace Zakładu Archeologii Antycznej IHKM PAN 1). Warszawa: Instytut Historii Kultury Materialnej PAN.

Krawczuk A. 1957. Z zagadnień krytyki źródeł do dziejów metalurgii antycznej: mosiądz i cynk w starożytności. Kwartalnik Historii Kultury Materialnej 5, 283-287.

Kunisz A. 1969. Chronologia naptywu pieniądza rzymskiego na ziemie Małopolski. Wrocław-Warszawa-Kraków: Zakład Narodowy im. Ossolińskich.

Laurenze C. and Riederer J. 1980. Metallanalysen römischer Henkel. Berliner Beiträge zur Archäometrie 5, 37-42.

Lippmann E. O. 1919. Entstehung und Ausbreitung der Alchemie, mit einem Anhange: Zur älteren Geschichte der Metalle: ein Beitrag zur Kulturgeschichte. Berlin: Springer.

Lityńska-Zając M. 1997. Roślinność i gospodarka rolna $w$ okresie rzymskim. Studium archeobotaniczne. Kraków: Instytut Archeologii i Etnologii PAN. Oddział w Krakowie.

Lloyd-Morgan G. 1981. Description of the Collections in the Rijksmuseum G.M. Kam at Nijmegen IX, The mirrors. Nijmegen: Provincial Museum G. M. Kam. 
Lund Hansen U. and Przybyła M. J. 2010 Rosettenfibeln - ein Klassifikationsversuch. In U. Lund Hansen and A. Bitner-Wróblewska (eds), Worlds Apart? Contacts across the Baltic Sea in the Iron Age. network Denmark-Poland 2005-2008 (= Nordiske Fortidsminder, serie C/7). København-Warszawa: Det Kongelige Nordiske Oldkriftselskab - Państwowe Muzeum Archeologiczne, 241-286.

Madyda-Legutko R. 1987. Gürtelschnallen der Römischen Kaiserzeit und der frühen Völkerwanderungzeit im mitteleuropäischen Barbaricum (= British Archaeological Reports. International Series 360). Oxford: Archaeopress.

Madyda-Legutko R., Rodzińska-Nowak J. and Zagórska-Telega J. 2007. Wyniki dalszych badań na cmentarzysku kultury przeworskiej w Prusieku stan. 25, pow. Sanok. Rocznik Przemyski 43(2), 61-69.

Madyda-Legutko R., Rodzińska-Nowak J. and Zagórska-Telega J. 2010. Złote wisiorki z cmentarzyska ludności kultury przeworskiej w Prusieku, stan. 25, gm. Sanok, In A. Urbaniak, R. Prochowicz, I. Jakubczyk, M. Leveda and J. Schuster (eds.), Terra Barbarica. Studia ofiarowane Magdalenie Mączyńskiej w 65. rocznicę urodzin (= Monumenta Archaeologica Barbarica, Series Gemina 2). Łódź-Warszawa: Instytut Archeologii Uniwersytetu Łódzkiego - Fundacja Uniwersytetu Łódzkiego - Fundacja Monumenta Archaeologica Barbarica - Państwowe Muzeum Archeologiczne w Warszawie, 387-395.

Maréchal J. R. 1961. La présence du zinc dans les bronzer Romains gaulois et germaniques et les débuts da la fabrication du lation. Ogam 13, 265-270.

Maréchal J. R. 1984. L'utilisation du zinc et de ses alliages dans l'Antiquité. Revue Archéologique Sites 19, 20-22.

Marold E. 2012. Mythische Schmiede in deutscher und Skandinavischer Sagentradition. In A. Pesch and R. Blankenfeldt (eds.), Goldsmith Mysteries. Archaeological, pictorial and documentary evidence from the $1^{\text {st }}$ millennium $A D$ in northern Europe. Schleswig: Wachholtz Verlag, 225242.

Maryon H. 1971. Metalwork and enamelling. A practical treatise on gold and silversmiths'work and their allied crafts. New York: Dover Publication, INC.

Mączyńska M. 2003. Die sogenannten „sarmatischen” Fibeln in Mittel- und Osteuropa, In C. von Carnap-Bornheim (ed.), Kontakt - Kooperation - Konflikt. Germanen und Sarmaten zwischen dem 1. und dem 4. Jahrhundert nach Christus. Neumünster: Wachholtz Verlag, 303332.

Mączyńska M. 2011. Der frühvölkerwanderungszeitlische Hortfund aus Łubiana, Kreis Kościerzyna. Bericht der Römisch-Germanischen Kommission 90 (2009), 7-481.

Mączyńska M. and Rudnicka D. 1998. Uwagi wstępne o skarbie z okresu rzymskiego z Łubianej, woj. gdańskie. In J. Kolendo (ed.), Nowe znaleziska importów rzymskich z ziem Polski 1. Korpus znalezisk rzymskich importów z europejskiego Barbaricum, Suplement B 1. Warszawa: Instytut Archeologii UW. Zakład Kontaktów Świata Śródziemnomorskiego z Barbaricum, 41-51.

Meeks N. 1995. A Technical study of Roman bronze mirrors. In S. T. A. M. Mols, A. M. GerhartlWitteveen, H. Kars, A. Koster, W. J. T. H. Peters and W. J. H. Willems (eds), Acta of the $12^{\text {th }}$ 
international congress on ancient bronzes Nijmegen 1992. Nijmegen: Provincial Museum G. M. Kam, 179-193.

von Müller A. 1957. Formenkreise der älteren römischen Kaiserzeit im Raum zwischen Havelseeplatte und Ostsee (= Berliner Beiträge zur Vor- und Frühgesichte 1). Berlin: De Gruyter.

Natuniewicz M. 2000. „Nowe” znaleziska ze starych wykopalisk. Ocalałe materiały archeologiczne z okresu wpływów rzymskich z okolic Elbląga. In J. Kolendo and W. Nowakowski (eds.), Antiquitates Prussiae. Studia z archeologii dawnych ziem pruskich. Warszawa: Instytut Archeologii Uniwersytetu Warszawskiego, 105-206.

Natuniewicz-Sekuła M. 2010. Unikatowy, „brązowy” dzban rzymski w stylu egiptyzującym z Weklic nowe odkrycia... In A. Urbaniak, R. Prochowicz, I. Jakubczyk, M. Levada and J. Schuster (eds), Terra Barbarica. Studia ofiarowane Magdalenie Mączyńskiej w 65. rocznicę urodzin (= Monumenta Archaeologica Barbarica, Series Gemina 2). Łódź-Warszawa: Instytut Archeologii Uniwersytetu Łódzkiego - Fundacja Uniwersytetu Łódzkiego - Fundacja Monumenta Archaeologica Barbarica - Państwowe Muzeum Archeologiczne w Warszawie, 397-416.

Natuniewicz-Sekuła M. 2013. Złotnictwo społeczności kultury wielbarskiej Wysoczyzny Elbląskiej ze szczególnym uwzględnieniem wybranych zabytków z cmentarzyska $w$ Weklicach. Warszawa (unpublished PhD Thesis in the archive of IAE PAN).

Natuniewicz-Sekuła M. 2017. Kolejny wielbarski pochówek z elementami bałtyjskimi (?) z cmentarzyska w Weklicach, pow. elbląski. In J. Andrzejowski, C. von Carnap-Bornheim, A. Cieśliński and B. Kontny (eds.), Orbis barbarorum. Studia ad archaeologiam Germanorum et Baltorum temporibus Imperii Romani pertinentia Adalberto Nowakowski dedicata (= Monumenta Archaeologica Barbarica, Series Gemina 6). Warszawa-Schleswig: Instytut Archeologii Uniwersytetu Warszawskiego - Zentrum für Baltische und Skandinavische Archäologie Fundacja Monumenta Archaeologica Barbarica, 461-471.

Natuniewicz-Sekuła M. and Okulicz-Kozaryn J. 2007. Wybrane groby z importami rzymskimi z cmentarzyska w Weklicach, pow. elbląski, stan. 7. Wiadomości Archeologiczne 59, 45-75.

Natuniewicz-Sekuła M. and Okulicz-Kozaryn J. 2008. Two richly furnished graves with Roman imports from the cemetery at Weklice, site 7, Elbląg commune (Poland). Germania 86, 227-269.

Natuniewicz-Sekuła M. and Okulicz-Kozaryn J. 2011. Weklice. A Cemetery of Wielbark Culture on the Eastern Margin of Vistula Delta (excavations 1984-2004) (= Monumenta Archaeologica Barbarica 17). Warszawa: Fundacja Monumenta Archaeologica Barbarica - Instytut Archeologii i Etnologii Polskiej Akademii Nauk - Państwowe Muzeum Archeologiczne w Warszawie.

Natuniewicz-Sekuła M. and Skóra K. 2016. Selected Children's burials from the Wielbark Culture cemetery at Weklice, Site 7, Elbląg commune, warmińsko-mazurskie voivodeship. Archaeologia Polona 51-52, 43-79.

Nestler G. and Formigli E. 1994. Granulazione etrusca. Un' antica arte orafa. Siena: Nuova Immagine.

Neuburger A. 1919. Die Technik des Altertums. Leipzig: R. Voigtländer Verlag.

Niewęgłowski A. 1986. Problemy i metody metaloznawczych badań starożytnych wyrobów z miedzi i jej stopów. Kwartalnik Historii Kultury Materialnej 34(2), 294-308. 
Niewęgłowski A. 1988. Z badań nad technologią produkcji i pochodzeniem późnoceltyckich i rzymskich naczyń metalowych (w świetle analiz metaloznawczych). Kwartalnik Historii Kultury Materialnej 34(2), 189-232.

Niewęgłowski A. 1991. Produkcja i pochodzenie rzymskich naczyń „brązowych” w świetle analiz metaloznawczych. Kwartalnik Historii Kultury Materialnej 39(3), 279-316.

Nosek M. E. and Kowalska A. 2001. Technologia wykonania wybranych ozdób brązowych z cmentarzyska w Kowalewku, gm. Oborniki. In M. Chłodnicki (ed.), Kowalewko 12. Cmentarzysko birytualne ludności kultury wielbarskiej (od polowy I w. n. e. do początku III w. n. e.) (= Archeologiczne badania ratownicze wzdluż trasy gazociagu tranzytowego 2/3). Poznań: Wydawnictwo Poznańskie, 437-450.

Ohlhaver H. 1939. Der germanische Schmied und sein Werkzeug (= Hamburger Schriften zur Vorgeschichte und Germanischen Frühgeschichte 2). Leipzig: Verlag von Curt Kabitzsch.

Okulicz-Kozaryn J. 1992a. Centrum kulturowe z pierwszych wieków naszej ery u ujścia Wisły. Barbaricum 2. Warszawa: Instytut Archeologii Uniwersytetu Warszawskiego, 137-155.

Okulicz-Kozaryn J. 1992b. Ett kulturcentrum vid Weichsels mynning under de första århundradena av vår tideräkning. In I. Nordgren (ed.), Dokumentation av Folkvandrings- och Äldremedeltida Symposiet i Linköping 12-13 september 1992 (= Götiska Minnen 113; Olof Skötkonungslogens forskningsskrift 2). Lidköping: Olof Skotkonungslagen - Gotiska Forbundet, 83-107.

Oldeberg A. 1966. Metallteknik under vikingatid och medeltid. Stockholm: V. Pettersons.

Peiser F. E. and Kemke H. 1914. Der Depotfund von Frauenburg. Sitzungsberichte der Altertumsgesellschaft Prussia 23, 58-73.

Pernot M. 1998. Des ateliers métallurgiques près de la Porte du Rebout. In K. Gruel and D. Vitali (eds.), L'oppidum de Bibracte. Un bilan de onze années de recherche (1984-1995). Gallia 55, 52-6o.

Picon M. Condamin J. and Boucher S. 1966. Recherches téchniques sur des bronzes de Gaule Romaine. Gallia 24, 189-215.

Picon M. Condamin J. and Boucher S. 1969. Recherches téchniques sur des bronzes de Gaule romaine 3. Gallia 26(2), 245-278.

Pietrzak M. 1997. Pruszcz Gdański, Fundstelle 10, Ein Gräberfeld der Oksywie- und Wielbark-Kultur in Ostpommern (= Monumenta Archaeologica Barbarica 4). Kraków: Instytut Archeologii i Etnologii PAN - Muzeum Archeologiczne w Gdańsku.

Pietsch M. 1983. Die römischen Eisenwerkzeuge von Saalburg, Feldberg und Zugmantel. Saalburg Jahrbuch 39, 5-132.

Raddatz K. 1957. Der Thorsberger Moorfund, Gürtelteile und Körperschmuck (= Offa-Bücher 13). Neumünster: Wachholtz Verlag.

Rehren Th. 2003. Crucibles as reaction vessels in ancient metallurgy. In P. Craddock and J. Lang (eds.), Mining and Metal Production through the ages. London: British Museum Press, 207-215.

Riederer J. 1984. Metallanalysen römischer Bronzen. In U. Gehring (ed.), Toreutik und figürliche Bronzen römischer Zeit, Akten des 6 Tagung über antike Bronzen,13-17. Mai 198o in Berlin. Berlin: Staatliche Museen Preussischer Kulturbesitz - Antikenmuseum, 220-225. 
Riederer J. 1987. Archäologie und Chemie - Einblicke in die Vergangenheit, In Ausstellung des Rathgen-Forschungslabors SMPK, September 1987 - Januar 1988. Berlin: Staatliche Museen Preussischer Kulturbesitz - Rathgen-Forschungslabor.

Riederer J. and Breise E. 1972. Metallanalysen römischer Gebrauchsgegenstände. Jahrbuch des Römisch-Germanischen Zentralmuseums Mainz 19, 83-88.

Riha E. 1979. Die römischen Fibeln aus Augst und Kaiseraugst (= Forschungen in Augst 3). Augst: Stiftung Pro Augusta Raurica.

Romero A. M. 2006. Bibracte. Archéologie d'une ville gauloise. Glux-en-Glenne: Bibracte-Centre archéologique européen.

Skorupka T. 2001. Kowalewko 12. Cmentarzysko birytualne ludności kultury wielbarskiej (od połowy I w. n. e. do poczatku III w.n.e.) (= Archeologiczne badania ratownicze wzdluż trasy gazociagu tranzytowego 2/3). Poznań: Wydawnictwo Poznańskie.

Stawicki S. 1987. Papirusy Tebańskie. Antyczne źródło wiedzy o technikach artystycznych. Wrocław-Warszawa-Kraków-Gdańsk-Łódź: Zakład Narodowy im. Ossolińskich - Wydawnictwo Polskiej Akademii Nauk.

Stos-Gale Z. A. 1993. The origin of metals from Roman-period levels of a site in southern Poland. Journal of European Archeology 12, 101-131.

Strobin A. 2015. Osada kultury oksywskiej i wielbarskiej w Lipiankach, gm. Kwidzyń, stan. 3 (Część 2 źródła ruchome), In M. Fudziński and H. Paner (eds), Kontakty ponadregionalne kultury wielbarskiej. Przemiany kulturowe $w$ okresie wplywów rzymskich na Pomorzu. Gdańsk: Muzeum Archeologiczne w Gdańsku, 125-193.

Strobin J. 1995. Die Ornamentik des Metallschmucks aus dem Gräberfeld der Wielbark-Kultur in Lubowidz. In M. D. Wołągiewicz and W. Nowakowski (eds), Lubowidz. Ein birituelles Gräberfeld der Wielbark-Kultur aus der Zeit vom Ende des 1. Jhs.v.Chr. bis zum Anfang des 3. Jhs.n.Chr. (= Monumenta Archaeologica Barbarica 1). Kraków: Instytut Archeologii i Etnologii PAN - Muzeum Narodowe w Szczecinie, 51-56.

Strobin J. 1998. Filigran i granulacja w złotnictwie kultury wielbarskiej. Acta Archaeologica Pomoranica I, XII Sesja Pomorzoznawcza, Szczecin 23-24 października 1997. Szczecin: Stowarzyszenie Naukowe Archeologów Polskich oddział w Szczecinie, 127-131.

Strobin J. 2000. Modelowanie w ksztaltownikach. Uwagi na temat technik kucia w metaloplastyce kultury wielbarskiej. Światowit 2(43), 231-252.

Strobin J. 2007. Zdobienie foliami z metali szlachetnych $\mathrm{w}$ metaloplastyce kultury wielbarskiej na przykładzie zapinek płytowych z Pruszcza Gdańskiego, stan. 7, grób 150 oraz Pruszcza Gdańskiego, stan. 5, grób 17. In M. Fudziński and H. Paner (eds), Nowe materiaty i interpretacje. Stan badań na temat kultury wielbarskiej. Gdańsk: Muzeum Archeologiczne w Gdańsku, 673-681.

Strobin J. 2015. Okucie typu balteus jako przykład technik zdobniczych w złotnictwie barbarzyńskim młodszego okresu rzymskiego. In J. Gackowski (ed.) Linowo, stanowisko 6. Birytualne cmentarzysko kultury wielbarskiej z pótnocno-wschodniej części ziemi chetmińskiej, GrudziądzToruń: Muzeum im. ks. dr. Władysława Łęgi - Muzeum Okręgowe w Toruniu, 177-19o. 
Szmoniewski B. Sz. 2005. Odlewnictwo metali kolorowych w kulturze wczesnosłowiańskiej. In P. Kaczanowski and M. Parczewski (eds.), Archeologia o poczatkach Stowian. Materiały z konferencji, Kraków, 19-21 listopada 2001. Kraków: Instytut Archeologii Uniwersytetu Jagiellońskiego, 619-626.

Tejral J. 2006. Die germanische Gießereiwerkstatt in Pasohlávky (Bez. Břeclav). Ein Beitrag zur Frage der Fernhandels- und Kulturbeziehungen nach den Markomannenkriegen. Památky Archeologické 97, 133-170.

Tempelmann-Mączyńska M. 1985. Die Perlen der römischen Kaiserzeit und der frühen Phase der Völkerwanderungszeit im mitteleuropäischen Barbaricum (= Römisch-Germanische Forschungen 43). Mainz: Verlag Philipp von Zabern.

Tuszyńska M. 2005. Ulkowy. Cmentarzysko kultury wielbarskiej na Pomorzu Gdańskim. Gdańsk: Muzeum Archeologiczne w Gdańsku.

Vaday A. 2005. Adatok a szarmaták fémművességéhez (Tiszaföldvár-téglagyár). Szántó Kovács Múzeum Évkönyve 7, 151-198.

Walenta K. 2009. Leśno i mikroregion w okresie rzymskim. Chojnice: Muzeum Archeologiczno-Etnograficzne - Zakład Archeologii Pomorza Instytutu Archeologii Uniwersytetu Łódzkiego.

Walther W. 1996. Eine bronzene Fibelgussform der jüngeren römischen Kaiserzeit von Neunheilingen und weitere Zeugnisse frühen Giesserhandwerks aus dem Unstrut-Hainich-Kreis. Mühlhäuser Beitrage 19, 19-32.

Wielowiejski J. 1960. Przemiany gospodarcze i społeczne u ludności południowej Polski w okresie późnolateńskim i rzymskim. Materiały Starożytne 6, 7-426.

Wielowiejski J. 1969. Wpływ reform monetarnych w latach 63-215 na przyjmowanie srebrnych pieniędzy rzymskich przez ludy północne. Wiadomości Numizmatyczne 13(1), 1-18.

Wielowiejski J. 1970. Kontakty Noricum i Panonii z ludami pótnocnymi. Wrocław: Zakład Narodowy im. Ossolinskich.

Willers H. 1898. Römische Silberbarren mit Stempel. Numismatische Zeitschrift 30, 211-235.

Wolters J. 1975. Zur Geschichte der Löttechnik. Hanau-Wolfgang: Degussa.

Wolters J. 1986. Die Granulation. Geschichte und Technik einer alten Goldschmiedekuns. Münschen: Callwey Verlag.

Wołągiewicz R. 1968. Chronologia względna okresu wczesnorzymskiego na Pomorzu Zachodnim w świetle niektórych jej wyznaczników. Materiały Zachodniopomorskie 12, 169-193.

Wołągiewicz R. 1970a. Napływ importów rzymskich do Europy na północ od środkowego Dunaju. Archeologia Polski 15(1), 207-252.

Wołągiewicz R. 1970b. Zur Zufluß römischer Importe in das Gebiet nördlich der mittleren Donau in der älteren Kaiserzeit. Zeitschrift für Archäologie 4(2), 222-249.

Wołągiewicz R. 1974. Zagadnienie stylu wczesnorzymskiego w kulturze wielbarskiej. In F. J. Lachowicz (ed.), Studia Archaeologica Pomerania. Koszalin: Muzeum Archeologiczno-Historyczne w Koszalinie, 129-152. 
Wójcik T. 1982. Pomorskie formy bransolet wężowatych z okresu rzymskiego. Materiały Zachodniopomorskie 24, 35-113.

Zapolska A. 2012. Znaleziska monet rzymskich z kręgu zachodniobałtyjskiego 1. Warszawa (unpublished PhD Thesis in the archive of IA UW).

Zastawniak F. 1995. Złotnictwo i probiernictwo. Kraków: „Od Nowa”, Spółka Wydawnicza.

Zoll-Adamikowa H., Dekówna M. and Nosek E. M. 1999. The Early Mediaeval Hoard from Zawada Lanckorońska (Upper Vistula River). Warszawa: Institute of Archaeology and Ethnology Polish Academy of Sciences. 



\section{THE CRAFT OF THE GOLDSMITH IN WIELBARK CULTURE IN THE LIGHT OF THE FINDS FROM THE CEMETERY AT WEKLICE, ELBLAG COMMUNE AND OTHER NECROPOLIS OF ROMAN PERIOD FROM ELBLĄG HEIGHTS. TECHNOLOGICAL STUDIES OF SELECTED ASPECTS}

Table 1. Results of the chemical composition analyzes, Group 1 - gold and its alloys, silver gilded and gold foils, electrum (prepared by M. Natuniewicz-Sekuła)

\begin{tabular}{|c|c|c|c|c|c|c|c|c|c|c|c|c|c|c|c|c|c|}
\hline No. & $\begin{array}{l}\text { Description of the find/the analyzed } \\
\text { part of find/Additional comments }\end{array}$ & $\begin{array}{l}\text { Grave no./ } \\
\text { inventory no. } \\
\text { /Chronology }^{2}\end{array}$ & Sample no. ${ }^{3}$ & Au & Si & $\mathrm{Cr}$ & Mn & $\mathbf{F e}$ & $\mathbf{N i}$ & $\mathbf{C u}$ & $\mathbf{Z n}$ & As & Ag & Sn & Sb & $\mathbf{P t}$ & Literature /figure no. \\
\hline 1 & $\begin{array}{l}\text { Silver, decorated gilded silver foil shield } \\
\text { brooch. The central foil with a portraits } \\
\text { of Mark Aurelius and Lucius Verus from } \\
\text { attire under the neck of character on the } \\
\text { right. The results of analysis other parts, } \\
\text { see Table } 2: 10-13 \text {. }\end{array}$ & $\begin{array}{c}208 \\
(803) \\
\text { stadium } \\
\text { IIIA/IIIB }\end{array}$ & 15530 & 83,75 & 0,74 & 0,01 & 0,07 & 0,2 & 0 & 0,39 & 0,01 & 0 & 14,84 & 0 & 0 & 0 & $\begin{array}{l}\text { Natuniewicz-Sekuła, } \\
\text { Okulicz-Kozaryn 2011, } \\
\text { 65-66, pl. LXXXIII:1 }\end{array}$ \\
\hline 2 & $\begin{array}{l}\text { Silver, decorated gilded silver foil shield } \\
\text { brooch. The foil with laurel wreath motif } \\
\text { surrounding the central foil. The results } \\
\text { of analysis other parts, see Table } 2: 10-13 \text {. }\end{array}$ & $\begin{array}{c}208 \\
(803) \\
\text { stadium } \\
\text { IIIA/IIIB }\end{array}$ & 15530,01 & 49,26 & 0,4 & 0,16 & 0,11 & 0,18 & 0,1 & 0,87 & 0 & 0 & 48,94 & 0 & 0 & 0 & $\begin{array}{l}\text { Natuniewicz-Sekuła, } \\
\text { Okulicz-Kozaryn 2011, } \\
\text { 65-66, pl. LXXXIII:1 }\end{array}$ \\
\hline 3 & $\begin{array}{l}\text { Gold biconical bead. Beaded wire at the } \\
\text { base of the cone. The lead content was } \\
\text { detected } \mathrm{Pb}=0,18 \text {. }\end{array}$ & $\begin{array}{c}208 \\
(796) \\
\text { stadium } \\
\text { IIIA/IIIB }\end{array}$ & 15532 & 98,79 & 0,51 & 0,09 & 0,04 & 0,16 & 0,01 & 0,19 & 0,01 & 0 & 0,01 & 0 & 0 & 0 & $\begin{array}{l}\text { Natuniewicz-Sekuła, } \\
\text { Okulicz-Kozaryn 2011, } \\
\text { 66, pl. LXXXIII:12. Fig. } \\
\text { 1:3 }\end{array}$ \\
\hline 4 & $\begin{array}{l}\text { Gold biconical bead. Beaded wire on one } \\
\text { of the hole of the cone. The lead content } \\
\text { was detected } \mathrm{Pb}=0,5 \text {. }\end{array}$ & $\begin{array}{c}208 \\
(797) \\
\text { stadium } \\
\text { IIIA/IIIB }\end{array}$ & 15533 & 98,06 & 0,54 & 0 & 0,06 & 0,2 & 0,03 & 0,28 & 0,03 & 0 & 0,3 & 0 & 0 & 0 & $\begin{array}{l}\text { Natuniewicz-Sekuła, } \\
\text { Okulicz-Kozaryn 2011, } \\
\text { 66, pl. LXXXIII:13. Fig. } \\
\mathbf{1 : 4 ; ~ 1 4 : 1 - 2 ~}\end{array}$ \\
\hline 5 & $\begin{array}{l}\text { Gold biconical bead. A smooth wire from } \\
\text { the cone. The lead content was detected } \\
\mathrm{Pb}=0,41 \text {. }\end{array}$ & $\begin{array}{c}208 \\
(797) \\
\text { stadium } \\
\text { IIIA/IIIB }\end{array}$ & 15533,01 & 97,59 & 0,82 & 0,01 & 0,01 & 0,36 & 0,03 & 0,65 & 0 & 0 & 0,14 & 0 & 0 & 0 & $\begin{array}{l}\text { Natuniewicz-Sekuła, } \\
\text { Okulicz-Kozaryn 2011, } \\
\text { 66, pl. LXXXIII:13. Fig. } \\
\text { 1:4; 14:1-2 }\end{array}$ \\
\hline 6 & $\begin{array}{l}\text { Gold S-shape clasp. Type von Müller B. } \\
\text { The central granule from the composition } \\
\text { at the base narrowness. The lead content } \\
\text { was detected } \mathrm{Pb}=0,38 \text {. }\end{array}$ & $\begin{array}{c}208 \\
(798) \\
\text { stadium } \\
\text { IIIA/IIIB }\end{array}$ & 15534 & 96,76 & 0,82 & 0,04 & 0,05 & 0,23 & 0,04 & 0,09 & 0,09 & 0 & 1,49 & 0 & 0 & 0 & $\begin{array}{l}\text { Natuniewicz-Sekuła, } \\
\text { Okulicz-Kozaryn 2011, } \\
\text { 66, pl. LXXXIII:11. Fig. } \\
\text { 1:2; 14:3-6 }\end{array}$ \\
\hline 7 & $\begin{array}{l}\text { Gold S-shape clasp. Type von Müller B. } \\
\text { Beaded wire from the base. The lead } \\
\text { content was detected } \mathrm{Pb}=0,75 \text {. }\end{array}$ & $\begin{array}{c}208 \\
(798) \\
\text { stadium } \\
\text { IIIA/IIIB }\end{array}$ & 15534,01 & 95,86 & 0,88 & 0,05 & 0,02 & 0,28 & 0 & 0,19 & 0,07 & 0 & 1,9 & 0 & 0 & 0 & $\begin{array}{l}\text { Natuniewicz-Sekuła, } \\
\text { Okulicz-Kozaryn 2011, } \\
\text { 66, pl. LXXXIII:11. Fig. } \\
\text { 1:2; 14:3-6 }\end{array}$ \\
\hline
\end{tabular}




\begin{tabular}{|c|c|c|c|c|c|c|c|c|c|c|c|c|c|c|c|c|c|}
\hline 8 & $\begin{array}{l}\text { Gold globular pendant. The body of } \\
\text { pendant. }\end{array}$ & $\begin{array}{c}45 \\
(222) \\
\text { stadium IIB }\end{array}$ & 15537 & 70,34 & 0,48 & 0,03 & 0,05 & 0,12 & 0,1 & 0,43 & 0,05 & 0 & 28,41 & 0 & 0 & 0 & \begin{tabular}{|l|} 
Natuniewicz-Sekuła, \\
Okulicz-Kozaryn 2011, \\
35, pl. XX:4. 4a. Fig. 1:6
\end{tabular} \\
\hline 9 & $\begin{array}{l}\text { Gold globular pendant. The central } \\
\text { granule from the composition of the body } \\
\text { bottom. }\end{array}$ & $\begin{array}{c}45 \\
(222) \\
\text { stadium IIB }\end{array}$ & 15537,01 & 75,48 & 0,43 & 0,02 & 0,03 & 0,16 & 0 & 0,19 & 0 & 0 & 23,7 & 0 & 0 & 0 & \begin{tabular}{|l|} 
Natuniewicz-Sekuła, \\
Okulicz-Kozaryn 2011, \\
35, pl. XX:4. 4a. Fig. 1:6 \\
\end{tabular} \\
\hline 10 & \begin{tabular}{|l|} 
Iron brooch, decorated silver, gilded \\
silver foil and filigree and granulation. \\
Type close to A. V, series 1 . The foil \\
from a central part of the bow. The lead \\
content was detected $\mathrm{Pb}=0,35$. The \\
results of analysis other parts, see Table \\
2:17.
\end{tabular} & $\begin{array}{c}26 \mathrm{~B} \\
(122) \\
\text { stadium IIB/IIC }\end{array}$ & 15540 & 88,98 & 0,53 & 0,39 & 0,02 & 0,48 & 0 & 0,08 & 0,07 & 0 & 9,08 & 0 & 0 & 0 & $\begin{array}{l}\text { Natuniewicz-Sekuła, } \\
\text { Okulicz-Kozaryn 2011, } \\
\text { 30, pl. X:1. 1a. Fig. 2:3 }\end{array}$ \\
\hline 11 & $\begin{array}{l}\text { Brass lunula pendant decorated silver } \\
\text { gilded foil. The foil from central part. } \\
\text { The lead content was detected } \mathrm{Pb}=0,54 \text {. } \\
\text { The results of analysis other parts, see } \\
\text { Table 2:29. }\end{array}$ & $\begin{array}{l}275 \\
(1222) \\
\text { stadium V }\end{array}$ & 15551 & 90,13 & 0,5 & 0,11 & 0 & 0,56 & 0 & 0,86 & 0,11 & 0 & 7,19 & 0 & 0 & 0 & $\begin{array}{l}\text { Natuniewicz-Sekuła, } \\
\text { Okulicz-Kozaryn 2011, } \\
\text { 80, pl. CXVII:9. Fig. 2:1 }\end{array}$ \\
\hline 12 & $\begin{array}{l}\text { Silver crossbow brooch with closed } \\
\text { catchplate, decorated silver gilded foil. } \\
\text { Type close to A. VI. } 170 \text {. The foil from } \\
\text { the spring arm. . The lead content was } \\
\text { detected } \mathrm{Pb}=0,51 \text {. The results of analysis } \\
\text { other parts, see Table } 2: 31 ; 4: 2 \text {. }\end{array}$ & $\begin{array}{c}275 \\
(1247) \\
\text { stadium V }\end{array}$ & 15552 & 75,56 & 0,41 & 0,1 & 0,01 & 0,13 & 0,02 & 0,23 & 0 & 0 & 23,02 & 0 & 0 & 0 & $\begin{array}{l}\text { Natuniewicz-Sekuła, } \\
\text { Okulicz-Kozaryn 2011, } \\
\text { 80, pl. CXVI:3. Fig. 2:2; } \\
\text { 4:6 }\end{array}$ \\
\hline 13 & $\begin{array}{l}\text { Silver crossbow tendril brooch, decorated } \\
\text { silver gilded foil. Type A. VI. 162. The } \\
\text { foil from the bow. The results of analysis } \\
\text { other parts, see Table 2:32-33. }\end{array}$ & $\begin{array}{c}150 \\
(605) \\
\text { stadium } \\
\text { IVA/IVB }\end{array}$ & 15554 & 83,52 & 0,34 & 0,05 & 0,03 & 0,3 & 0,02 & 0,98 & 0,1 & 0 & 14,67 & 0 & 0 & 0 & $\begin{array}{l}\text { Natuniewicz-Sekuła, } \\
\text { Okulicz-Kozaryn 2011, } \\
\text { 55, pl. LVIII:1 }\end{array}$ \\
\hline 14 & \begin{tabular}{|l|} 
Silver crossbow brooch with high \\
catchplate, so called Rosettenfibeln, \\
decorated gold foil, knobs made of brass. \\
Type close to A. VII, series 4 . Group 6 \\
after Lund Hansen, Przybyła. The foil \\
from the foot. The lead content was \\
detected $\mathrm{Pb}=0,01$. The results of analysis \\
other parts, see Table 2:34-35.
\end{tabular} & $\begin{array}{c}150 \\
(606) \\
\text { stadium } \\
\text { IVA/IVB }\end{array}$ & 15555 & 94,21 & 0,3 & 0,14 & 0,11 & 0,18 & 0 & 0,02 & 0,12 & 0 & 4,92 & 0 & 0 & 0 & $\begin{array}{l}\text { Natuniewicz-Sekuła, } \\
\text { Okulicz-Kozaryn 2011, } \\
\text { 55-56, pl. LX:3 }\end{array}$ \\
\hline 15 & \begin{tabular}{|l|} 
Silver crossbow brooch with high \\
catchplate, so called Rosettenfibeln, \\
decorated gold foil, knobs made of brass. \\
Type close to A. VII, series 4 . Group 6 \\
after Lund Hansen, Przybyła. The rosette \\
foil from the central knob on the bow. \\
The lead content was detected Pb=0,62. \\
The results of analysis other parts, see \\
Table 2:34-35.
\end{tabular} & $\begin{array}{c}150 \\
(606) \\
\text { stadium } \\
\text { IVA/IVB }\end{array}$ & 15555,01 & 83,38 & 0,57 & 0,05 & 0,12 & 0,24 & 0,08 & 0,4 & 0,07 & 0 & 14,48 & 0 & 0 & 0 & $\begin{array}{l}\text { Natuniewicz-Sekuła, } \\
\text { Okulicz-Kozaryn 2011, } \\
\text { 55-56, pl. LX:3 }\end{array}$ \\
\hline
\end{tabular}




\begin{tabular}{|c|c|c|c|c|c|c|c|c|c|c|c|c|c|c|c|c|c|}
\hline 16 & \begin{tabular}{|l|} 
Silver crossbow brooch with high \\
catchplate, so called Rosettenfibeln, \\
decorated gold foil, knobs made of brass. \\
Type close to A. VII, series 4 . Group 6 \\
after Lund Hansen, Przybyła. The foil \\
from the foot. The lead content was \\
detected $\mathrm{Pb}=0,32$. The results of analysis \\
other parts, see Table 2:36-38; $3: 10$. \\
\end{tabular} & $\begin{array}{c}150 \\
(607) \\
\text { stadium } \\
\text { IVA/IVB }\end{array}$ & 15556 & 83,62 & 0,54 & 0,12 & 0 & 0,25 & 0 & 0,27 & 0,21 & 0 & 14,67 & 0 & 0 & 0 & $\begin{array}{l}\text { Natuniewicz-Sekuła, } \\
\text { Okulicz-Kozaryn 2011, } \\
\text { 55-56, pl. LX:4 }\end{array}$ \\
\hline 17 & \begin{tabular}{|l|} 
Silver crossbow brooch with high \\
catchplate, so called Rosettenfibeln, \\
decorated gold foil, knobs made of brass. \\
Type close to A. VII, series 4 . Group 6 \\
after Lund Hansen, Przybyła. The roseate \\
foil from the central knob on the bow. \\
The lead content was detected $P b=1,15$. \\
The results of analysis other parts, see \\
Table 2:36-38; $3: 10$. \\
\end{tabular} & $\begin{array}{c}150 \\
(607) \\
\text { stadium } \\
\text { IVA/IVB }\end{array}$ & 15556,01 & 82,55 & 0,46 & 0,1 & 0,03 & 0,21 & 0 & 0,73 & 0,12 & 0 & 14,64 & 0 & 0 & 0 & $\begin{array}{l}\text { Natuniewicz-Sekuła, } \\
\text { Okulicz-Kozaryn 2011, } \\
\text { 55-56, pl. LX:4 }\end{array}$ \\
\hline 18 & $\begin{array}{l}\text { Silver crossbow tendril brooch, decorated } \\
\text { gold foil. Type A. VI. 162. The foil from } \\
\text { the bow. The results of analysis other } \\
\text { parts, see Table } 2: 44 \text {. }\end{array}$ & $\begin{array}{c}229 \\
(912) \\
\text { stadium IVA }\end{array}$ & 15560 & 91,49 & 0,23 & 0,02 & 0,04 & 0,28 & 0 & 0,8 & 0 & 0 & 7,12 & 0 & 0 & 0 & $\begin{array}{l}\text { Natuniewicz-Sekuła, } \\
\text { Okulicz-Kozaryn 2011, } \\
\text { 70, pl. XCIV:229/1 }\end{array}$ \\
\hline 19 & $\begin{array}{l}\text { Electrum globular pendant. The central } \\
\text { granule at the bottom of the body. The } \\
\text { lead content was detected } \mathrm{Pb}=0,29\end{array}$ & $\begin{array}{c}26 \mathrm{~B} \\
(121) \\
\text { stadium IIB/IIC }\end{array}$ & 15563 & 49,08 & 0,42 & 0 & 0,06 & 0,25 & 0,09 & 0,3 & 0,01 & 0 & 49,5 & 0 & 0 & 0 & \begin{tabular}{|l|} 
Natuniewicz-Sekuła, \\
Okulicz-Kozaryn 2011, \\
31, pl. XI:9. 9a. Fig. 1:7 \\
\end{tabular} \\
\hline 20 & $\begin{array}{l}\text { Electrum globular pendant. The body of } \\
\text { pendant. The lead content was detected } \\
\mathrm{Pb}=0,75 \text {. }\end{array}$ & \begin{tabular}{c|}
$26 \mathrm{~B}$ \\
$(121)$ \\
stadium IIB/IIC \\
\end{tabular} & 15563,01 & 48,2 & 0,43 & 0 & 0,07 & 0,21 & 0 & 0,79 & 0,03 & 0 & 49,53 & 0 & 0 & 0 & \begin{tabular}{|l|} 
Natuniewicz-Sekuła, \\
Okulicz-Kozaryn 2011, \\
31, pl. XI:9. 9a. Fig. 1:7 \\
\end{tabular} \\
\hline 21 & $\begin{array}{l}\text { Electrum globular pendant. Smooth wire } \\
\text { at the bottom of the body. The lead } \\
\text { content was detected } \mathrm{Pb}=0,29\end{array}$ & $\begin{array}{c}26 \mathrm{~B} \\
(121) \\
\text { stadium IIB/IIC }\end{array}$ & 15563,02 & 48,95 & 0,37 & 0,07 & 0 & 0,26 & 0 & 0,36 & 0 & 0 & 49,69 & 0 & 0 & 0 & \begin{tabular}{|l|} 
Natuniewicz-Sekuła, \\
Okulicz-Kozaryn 2011, \\
31, pl. XI:9. 9a. Fig. 1:7 \\
\end{tabular} \\
\hline 22 & $\begin{array}{l}\text { Brass brooch with high catchplate and } \\
\text { cylinder for the spring, decorated silver } \\
\text { gilded foil. Type with features A. V. } \\
\text { series } 2 \text { and } 8 \text { and } \mathrm{A} \text {. VII, series } 1 \text {. The } \\
\text { foil from the comb on the head. The lead } \\
\text { content was detected } \mathrm{Pb}=0,17 \text {. The } \\
\text { results of analysis other parts, see Table } \\
\text { 3:12. }\end{array}$ & $\begin{array}{c}184 \\
(677) \\
\text { stadium IVB }\end{array}$ & 15569 & 61,33 & 0,57 & 0,05 & 0,04 & 0,17 & 0 & 0,69 & 0 & 0 & 36,98 & 0 & 0 & 0 & $\begin{array}{l}\text { Natuniewicz-Sekuła, } \\
\text { Okulicz-Kozaryn 2011, } \\
\text { 62, pl. LXXVII:2 }\end{array}$ \\
\hline 23 & $\begin{array}{l}\text { Gold globular pendant. The body of } \\
\text { pendant. The lead content was detected } \\
\mathrm{Pb}=1,11 \text {. }\end{array}$ & $\begin{array}{c}360 \\
(1751) \\
\text { stadium IIA }\end{array}$ & 15574 & 93,07 & 0 & 0,11 & 0 & 0,3 & 0,03 & 0,15 & 0 & 0 & 5,23 & 0 & 0 & 0 & \begin{tabular}{|l|} 
Natuniewicz-Sekuła, \\
Okulicz-Kozaryn 2011, \\
96, pl. CLVIII:4. Fig. 1:5
\end{tabular} \\
\hline 24 & $\begin{array}{l}\text { Gold globular pendant. Smooth wire } \\
\text { from the suspension loop. The lead } \\
\text { content was detected } \mathrm{Pb}=0,65 \text {. }\end{array}$ & $\begin{array}{c}360 \\
(1751) \\
\text { stadium IIA }\end{array}$ & 15574,01 & 94,27 & 0 & 0,06 & 0,01 & 0,28 & 0,03 & 0,12 & 0 & 0 & 4,59 & 0 & 0 & 0 & \begin{tabular}{|l|} 
Natuniewicz-Sekuła, \\
Okulicz-Kozaryn 2011, \\
96, pl. CLVIII:4. Fig. 1:5
\end{tabular} \\
\hline
\end{tabular}




\begin{tabular}{|c|c|c|c|c|c|c|c|c|c|c|c|c|c|c|c|c|c|}
\hline 25 & $\begin{array}{l}\text { Iron brooch, decorated silver gilded foil. } \\
\text { Type close to } \mathrm{A} \text {. V. } 132 \text {. The foil from } \\
\text { the comb on the head. The lead content } \\
\text { was detected } \mathrm{Pb}=0,04 \text {. }\end{array}$ & $\begin{array}{c}434 \\
(2230) \\
\text { stadium } \\
\text { IIIA/IIIB } \\
\end{array}$ & 15578 & 87,16 & 0,42 & 0,12 & 0,07 & 1,17 & 0,09 & 0,36 & 0,09 & 0 & 10,48 & 0 & 0 & 0 & $\begin{array}{l}\text { Natuniewicz-Sekuła, } \\
\text { Okulicz-Kozaryn 2011, } \\
\text { 110, pl. CLXXXIX:434/3 }\end{array}$ \\
\hline 26 & \begin{tabular}{|l|} 
Silver and brass (tongue on the \\
catchplate) brooch with high catchplate, \\
so called Rosettenfibeln, decorated silver \\
gilded foil. Lubieszewo, Nowy Dwór \\
Gdański district. Type close to A. VII, \\
series 4. Group 6 after Lund Hansen, \\
Przybyła. The foil from the tongue on the \\
foot. The lead content was detected \\
$\mathrm{Pb}=0,43$. The results of analysis other \\
parts, see Table $2: 78-79 ; 3: 16 ; 4: 3$.
\end{tabular} & $\begin{array}{l}10 \\
\text { (collections of } \\
\text { the Museum of } \\
\text { Archaeology and } \\
\text { History in Elblag, } \\
\text { without inventory } \\
\text { no. ) phase C1b } \\
\text { to the beginning } \\
\text { C2 }\end{array}$ & 15590 & 75 & 0,59 & 0,01 & 0,01 & 0,31 & 0 & 0,61 & 0 & 0 & 23,05 & 0 & 0 & 0 & $\begin{array}{l}\text { Jonakowski 2001, 187, } \\
\text { fig. } 2: 7\end{array}$ \\
\hline 27 & \begin{tabular}{|l|} 
Silver and brass (tongue on the \\
catchplate) brooch with high catchplate, \\
so called Rosettenfibeln, decorated silver \\
gilded foil. Lubieszewo, Nowy Dwór \\
Gdański district. Type close to A. VII, \\
series 4 . Group 6 after Lund Hansen, \\
Przybyła. The rosette foil from the bigger \\
knob on the bow. The lead content was \\
detected $\mathrm{Pb}=35.2: 78-79 ; 3: 16 ; 4: 3$. \\
\end{tabular} & \begin{tabular}{|c|}
10 \\
(collections of \\
the Museum of \\
Archaeology and \\
History in Elblag, \\
without inventory \\
no. ) phase C1b \\
to the beginning \\
C2 \\
\end{tabular} & 15590,01 & 73,88 & 0,33 & 0 & 0,01 & 0,25 & 0,01 & 0,41 & 0 & 0,05 & 24,71 & 0 & 0 & 0 & $\begin{array}{l}\text { Jonakowski 2001, 187, } \\
\text { fig. } 2: 7\end{array}$ \\
\hline 28 & \begin{tabular}{|l|} 
Silver and brass (tongue on the \\
catchplate) brooch with high catchplate, \\
so called Rosettenfibeln, decorated silver \\
gilded foil. Lubieszewo, Nowy Dwór \\
Gdański district. Type close to A. VII, \\
series 4 . Group 6 after Lund Hansen, \\
Przybyła. The rosette foil from the \\
smaller knob on the bow. The lead \\
content was detected $\mathrm{Pb}=5,27$. The \\
results of analysis other parts, see Table \\
2:78-79; 3:16; $4: 3$. \\
\end{tabular} & \begin{tabular}{|c|}
10 \\
(collections of \\
the Museum of \\
Archaeology and \\
History in Elblag, \\
without inventory \\
no. ) phase C1b \\
to the beginning \\
C2
\end{tabular} & 15590,02 & 55,98 & 0,45 & 0,13 & 0 & 0,28 & 0 & 1,25 & 0 & 0,18 & 36,47 & 0 & 0 & 0 & $\begin{array}{l}\text { Jonakowski 2001, 187, } \\
\text { fig. } 2: 7\end{array}$ \\
\hline 29 & $\begin{array}{l}\text { Silver and brass (tongue on the } \\
\text { catchplate) brooch with high catchplate, } \\
\text { so called Rosettenfibeln, decorated silver } \\
\text { gilded foil. Lubieszewo, Nowy Dwór } \\
\text { Gdański district. Type close to A. VII, } \\
\text { series } 4 \text {. Group } 6 \text { after Lund Hansen, } \\
\text { Przybyła. The foil from the tongue on the } \\
\text { foot. The lead content was detected } \\
\mathrm{Pb}=3,91 \text {. The results of analysis other } \\
\text { parts, see Table } 2: 80 \text {. }\end{array}$ & \begin{tabular}{|c|}
10 \\
(collections of \\
the Museum of \\
Archaeology and \\
History in Elblag, \\
without inventory \\
no. ) phase C1b \\
to the beginning \\
C2
\end{tabular} & 15591 & 55,18 & 0,26 & 0,09 & 0,04 & 0,39 & 0 & 1,75 & 0 & 0 & 38,38 & 0 & 0 & 0 & $\begin{array}{l}\text { Jonakowski 2001, 187, } \\
\text { fig. 2:8 }\end{array}$ \\
\hline
\end{tabular}




\begin{tabular}{|c|c|c|c|c|c|c|c|c|c|c|c|c|c|c|c|c|c|c|c|}
\hline No. & $\begin{array}{c}\text { Description of the find/the } \\
\text { analyzed part of } \\
\text { find/Additional comments }\end{array}$ & \begin{tabular}{|c|} 
Grave no. / \\
inventory no. \\
/chronology
\end{tabular} & Sample no. & Au & $\mathrm{Si}$ & Al & $\mathrm{Cr}$ & Mn & $\mathbf{F e}$ & $\mathrm{Ni}$ & $\mathbf{C u}$ & Zn & As & Ag & Sn & Sb & Pt & $\mathbf{P b}$ & $\begin{array}{l}\text { Literature / } \\
\text { figure no. }\end{array}$ \\
\hline 30 & \begin{tabular}{|l|} 
Silver crossbow brooch with \\
high catchplate, so called \\
Rosettenfibeln, decorated gold \\
foil. Type close to A. VII, \\
series 4. Group 6 after Lund \\
Hansen, Przybyła. The rosette \\
foil from the central knob on \\
the bow. The results of \\
analysis other parts, see Table \\
2:81. \\
\end{tabular} & $\begin{array}{c}\text { stray } \\
\text { find(2466)phas } \\
\text { e C1b to } \\
\text { beginning C2 }\end{array}$ & 16139 & 92,37 & 0 & 0 & 0,07 & 0 & 0,65 & 0,05 & 0,92 & 0,22 & 0,09 & 5,33 & 0,11 & 0 & 0,19 & 0 & \begin{tabular}{|l|} 
Natuniewicz- \\
Sekuła 2010, 414, \\
fig. 9:11
\end{tabular} \\
\hline 31 & \begin{tabular}{|l|} 
Silver crossbow tendril \\
brooch, decorated gold foil. \\
Type A. VI. 162 . Foil from \\
the bow. The results of \\
analysis other parts, see Table \\
2:84. \\
\end{tabular} & $\begin{array}{c}\text { stray find } \\
(2445) \text { phase } \\
\text { C1b to } \\
\text { beginning C2 }\end{array}$ & 16146 & 94,89 & 0 & 0 & 0 & 0 & 0,68 & 0,16 & 0,41 & 0,48 & 0 & 2,78 & 0,38 & 0,23 & 0 & 0 & \begin{tabular}{|l|} 
Natuniewicz- \\
Sekuła 2010, 414, \\
fig. 9:9. Fig. 2:4
\end{tabular} \\
\hline 32 & \begin{tabular}{|l|} 
Fragment of silver crossbow \\
brooch with closed catchplate, \\
decorated gold foil. Type A. \\
VI. 170. The foil from the end \\
of foot. The results of analysis \\
other parts, see Table 2:96.
\end{tabular} & $\begin{array}{c}\text { stray } \\
\text { find( } 2718) \text { phas } \\
\text { e C1b to } \\
\text { beginning C2 }\end{array}$ & 16168 & 88,64 & 0 & 0 & 0,07 & 0 & 0,94 & 0 & 1,57 & 0,33 & 0 & 7,12 & 0,3 & 0 & 0 & 1,03 & $\begin{array}{l}\text { Natuniewicz- } \\
\text { Sekuła 2010, 414, } \\
\text { fig. 9:10 }\end{array}$ \\
\hline 33 & \begin{tabular}{|l|} 
Brass capsule pendant, \\
decorated silver gilded foil. \\
Foil in the central part of the \\
pendant. The results of \\
analysis other parts, see Table \\
3:48.
\end{tabular} & $\begin{array}{l}\text { 278(1313) } \\
\text { stadium } \\
\text { IIB/IIC }\end{array}$ & 16197 & 66,52 & 0 & 0 & 0,13 & 0,28 & 0,17 & 0,04 & 9,55 & 0 & 0,14 & 22,8 & 0,01 & 0 & 0,37 & 0 & \begin{tabular}{|l|} 
Natuniewicz- \\
Sekuła, Okulicz- \\
Kozaryn 2011, 81, \\
pl. CXXII:278/2
\end{tabular} \\
\hline 34 & $\begin{array}{l}\text { Electrum pear shape } \\
\text { pendantThe pendant body. } \\
\text { The results of analysis other } \\
\text { parts, see Table } 4: 1 \text {. }\end{array}$ & $\begin{array}{l}544(2798) \\
\text { stadium } \\
\text { IIB/IIC }\end{array}$ & 16224 & 39,84 & 0 & 0 & 0,13 & 0,08 & 0,29 & 0 & 6,87 & 0,23 & 0,27 & 51,21 & 0,73 & 0,35 & 0 & 0 & Fig. 1:8 \\
\hline 35 & $\begin{array}{l}\text { Gold S-shape clasp. Type von } \\
\text { Müller B. Beaded wire from } \\
\text { the base. }\end{array}$ & $\begin{array}{c}\text { stray } \\
\text { find(2913)phas } \\
\text { e B2/C1 -C1a }\end{array}$ & 16225 & 90,34 & 0,76 & 0 & 0,06 & 0 & 0,39 & 0,19 & 0,23 & 0 & 0 & 6 & 0 & 0,01 & 2,03 & 0 & $\begin{array}{l}\text { Natuniewicz- } \\
\text { Sekuła 2010, 414, } \\
\text { fig. 11:36. Fig. 1:1 }\end{array}$ \\
\hline
\end{tabular}




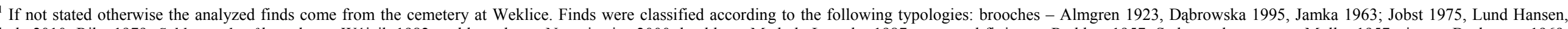

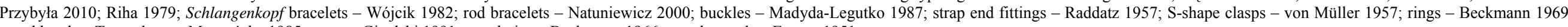
metal beads - Tempelmann-Mączyńska 1985; spurs - Ginalski 1991; metal pins - Beckmann 1966; metal vessels - Eggers 1951

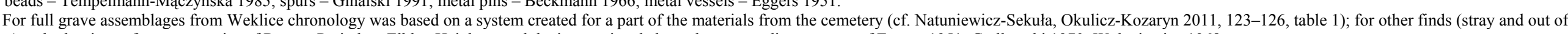
context) and other items from cemeteries of Roman Period on Elblagg Heights, used the interregional chronology according systems of Eggers 1951; Godłowski 1970; Wołagiewicz 1968.

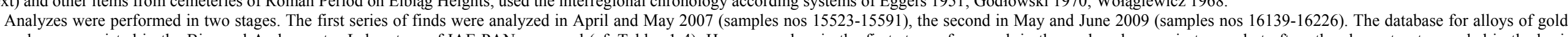

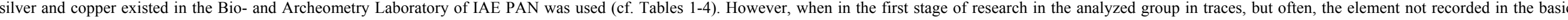

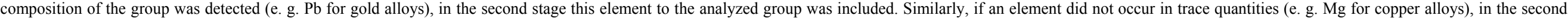
stage of analysis was excluded from a group of analyzed elements. The individual values of the constituent elements are given in weight percentages, while 0 is the result below of method detection. 
Table 2. Results of the chemical composition analyzes, Group 2 - silver and its alloys and silver foils (prepared by M. Natuniewicz-Sekuła)

\begin{tabular}{|c|c|c|c|c|c|c|c|c|c|c|c|c|c|c|c|c|c|c|}
\hline No. & $\begin{array}{c}\text { Description of the } \\
\text { find/the analyzed part } \\
\text { of find/Addditional } \\
\text { comments }\end{array}$ & $\begin{array}{c}\text { Grave no./ } \\
\text { inventory no./ } \\
\text { chronology }\end{array}$ & Sample no. & Ag & $\mathrm{Cu}$ & Al & $\mathrm{Si}$ & $\mathrm{Cr}$ & Mn & $\mathbf{F e}$ & $\mathbf{N i}$ & Zn & As & Sn & $\mathbf{A u}$ & $\mathbf{P b}$ & $\mathrm{S}$ & $\begin{array}{l}\text { Literature / } \\
\text { figure no. }\end{array}$ \\
\hline 1 & \begin{tabular}{|l|} 
Silver wellenförmige \\
bracelet with decorative \\
capsule fastening. The \\
lateral part of capsule. \\
\end{tabular} & $\begin{array}{c}208 \\
(809) \\
\text { stadium } \\
\text { IIIA/IIIB } \\
\end{array}$ & 15523 & 98,21 & 0,89 & 0,33 & 0,14 & 0,06 & 0,03 & 0,15 & 0,04 & 0 & 0 & 0 & 0,15 & 0 & 0 & \begin{tabular}{|l|} 
Natuniewicz- \\
Sekuła, Okulicz- \\
Kozaryn 2011, 66, \\
pl. LXXXIV:7 \\
\end{tabular} \\
\hline 2 & $\begin{array}{l}\text { Silver wellenförmige } \\
\text { bracelet with decorative } \\
\text { capsule fastening. Wire } \\
\text { from the hoop. }\end{array}$ & $\begin{array}{c}208 \\
(809) \\
\text { stadium } \\
\text { IIIA/IIIB } \\
\end{array}$ & 15523,01 & 97,47 & 1,76 & 0,32 & 0,06 & 0,02 & 0,03 & 0,13 & 0 & 0,02 & 0 & 0 & 0 & 0,18 & 0 & \begin{tabular}{|l|} 
Natuniewicz- \\
Sekuła, Okulicz- \\
Kozaryn 2011, 66, \\
pl. LXXXIV:7 \\
\end{tabular} \\
\hline 3 & \begin{tabular}{|l|} 
Silver spring-cover \\
brooch. Type A.II.40-41. \\
The underside of the bow \\
by the catchplate.
\end{tabular} & $\begin{array}{c}208 \\
(800) \\
\text { stadium } \\
\text { IIIA/IIIB }\end{array}$ & 15524 & 94,6 & 4,31 & 0,34 & 0,06 & 0,01 & 0 & 0,14 & 0 & 0 & 0,11 & 0 & 0 & 0,43 & 0 & \begin{tabular}{|l|} 
Natuniewicz- \\
Sekuła, Okulicz- \\
Kozaryn 2011, 66, \\
pl. LXXXIII:3 \\
\end{tabular} \\
\hline 4 & \begin{tabular}{|l|} 
Silver spring-cover \\
brooch. Type A.II.40-41. \\
The underside of the bow \\
by the catchplate.
\end{tabular} & $\begin{array}{c}208 \\
(802) \\
\text { stadium } \\
\text { IIIA/IIIB }\end{array}$ & 15525 & 94,65 & 4,25 & 0,88 & 0 & 0,01 & 0,07 & 0,07 & 0 & 0,07 & 0 & 0 & 0 & 0 & 0 & \begin{tabular}{|l|} 
Natuniewicz- \\
Sekuła, Okulicz- \\
Kozaryn 2011, 66, \\
pl. LXXXIII:2 \\
\end{tabular} \\
\hline 5 & $\begin{array}{l}\text { Silver crossbow brooch } \\
\text { with high catchplate. } \\
\text { Type A.VII, series } 1 . \\
\text { From the foot. }\end{array}$ & $\begin{array}{l}\text { 208(801) } \\
\text { stadium } \\
\text { IIIA/IIIB }\end{array}$ & 15526 & 97,43 & 1,57 & 0,34 & 0,07 & 0,1 & 0,11 & 0,2 & 0,01 & 0,03 & 0 & 0 & 0,04 & 0,11 & 0 & \begin{tabular}{|l|} 
Natuniewicz- \\
Sekuła, Okulicz- \\
Kozaryn 2011, 66, \\
pl. LXXXIII:4 \\
\end{tabular} \\
\hline 6 & $\begin{array}{l}\text { Silver Schlangenkopf } \\
\text { bracelet. Type close to } \\
\text { Wójcik IIIA. From the } \\
\text { bow narrowness. }\end{array}$ & $\begin{array}{c}208 \\
(806) \\
\text { stadium } \\
\text { IIIA/IIIB }\end{array}$ & 15527 & 96,9 & 2,53 & 0,25 & 0,11 & 0,07 & 0,01 & 0,1 & 0 & 0 & 0 & 0 & 0,03 & 0 & 0 & \begin{tabular}{|l|} 
Natuniewicz- \\
Sekuła, Okulicz- \\
Kozaryn 2011, 66, \\
pl. LXXXIV:5. \\
Fig. 4:5 \\
\end{tabular} \\
\hline 7 & $\begin{array}{l}\text { Silver Schlangenkopf } \\
\text { bracelet. Type close to } \\
\text { Wójcik IIIA. From the } \\
\text { bow narrowness. }\end{array}$ & $\begin{array}{c}208 \\
(804) \\
\text { stadium } \\
\text { IIIA/IIIB }\end{array}$ & 15528 & 97,14 & 2,19 & 0,32 & 0,08 & 0,04 & 0,03 & 0,16 & 0 & 0 & 0 & 0 & 0 & 0,05 & 0 & \begin{tabular}{|l|} 
Natuniewicz- \\
Sekuła, Okulicz- \\
Kozaryn 2011, 66, \\
pl. LXXXIV:6. \\
Fig. 4:4
\end{tabular} \\
\hline 8 & $\begin{array}{l}\text { Silver wellenförmige } \\
\text { bracelet with decorative } \\
\text { capsule fastening. Wire } \\
\text { from the hoop. }\end{array}$ & $\begin{array}{c}208 \\
(805) \\
\text { stadium } \\
\text { IIIA/IIIB }\end{array}$ & 15529 & 96,79 & 2,41 & 0,23 & 0,04 & 0,01 & 0,08 & 0,04 & 0,03 & 0,03 & 0 & 0 & 0,12 & 0,2 & 0 & \begin{tabular}{|l|} 
Natuniewicz- \\
Sekuła, Okulicz- \\
Kozaryn 2011, 66, \\
pl. LXXXIV:8 \\
\end{tabular} \\
\hline 9 & $\begin{array}{l}\text { Silver wellenförmige } \\
\text { bracelet with decorative } \\
\text { capsule fastening. The } \\
\text { lateral part of capsule. }\end{array}$ & $\begin{array}{c}208 \\
(805) \\
\text { stadium } \\
\text { IIIA/IIIB }\end{array}$ & 15529,01 & 97,84 & 1,19 & 0,18 & 0,45 & ,04 & 0,07 & 0,14 & 0 & 0 & 0 & 0 & 0,09 & 0 & 0 & \begin{tabular}{|l|} 
Natuniewicz- \\
Sekuła, Okulicz- \\
Kozaryn 2011, 66, \\
pl. LXXXIV:8 \\
\end{tabular} \\
\hline
\end{tabular}




\begin{tabular}{|c|c|c|c|c|c|c|c|c|c|c|c|c|c|c|c|c|c|c|}
\hline 10 & $\begin{array}{l}\text { Silver, decorated gilded } \\
\text { silver foil shield brooch. } \\
\text { The pin of the brooch. } \\
\text { The results of analysis } \\
\text { other parts, see Table } \\
\text { 1:1-2. }\end{array}$ & $\begin{array}{c}208 \\
(803) \\
\text { stadium } \\
\text { IIIA/IIIB }\end{array}$ & 15530 & 95,14 & 2,73 & 0,29 & 0,02 & 0,01 & 0,09 & 0,2 & 0,02 & 1,35 & 0 & 0 & 0 & 0,15 & 0 & $\begin{array}{l}\text { Natuniewicz- } \\
\text { Sekuła, Okulicz- } \\
\text { Kozaryn 2011, } \\
\text { 65-66, pl. } \\
\text { LXXXIII:1 }\end{array}$ \\
\hline 11 & $\begin{array}{l}\text { Silver, decorated gilded } \\
\text { silver foil shield brooch. } \\
\text { The underside of the } \\
\text { shield. The results of } \\
\text { analysis other parts, see } \\
\text { Table 1:1-2. }\end{array}$ & $\begin{array}{c}208 \\
(803) \\
\text { stadium } \\
\text { IIIA/IIIB }\end{array}$ & 15530,01 & 95,11 & 2,98 & 0,24 & 0,05 & 0 & 0 & 0,14 & 0 & 1,05 & 0 & 0 & 0,08 & 0,34 & 0 & $\begin{array}{l}\text { Natuniewicz- } \\
\text { Sekuła, Okulicz- } \\
\text { Kozaryn 2011, } \\
\text { 65-66, pl. } \\
\text { LXXXIII:1 }\end{array}$ \\
\hline 12 & $\begin{array}{l}\text { Silver, decorated gilded } \\
\text { silver foil shield brooch. } \\
\text { The brooch foot. The } \\
\text { results of analysis other } \\
\text { parts, see Table 1:1-2. }\end{array}$ & $\begin{array}{c}208 \\
(803) \\
\text { stadium } \\
\text { IIIA/IIIB }\end{array}$ & 15530,02 & 96,82 & 2,14 & 0,23 & 0 & 0 & 0,03 & 0,14 & 0,04 & 0,46 & 0 & 0 & 0 & 0,13 & 0 & $\begin{array}{l}\text { Natuniewicz- } \\
\text { Sekuła, Okulicz- } \\
\text { Kozaryn 2011, } \\
\text { 65-66, pl. } \\
\text { LXXXIII:1 } \\
\end{array}$ \\
\hline 13 & $\begin{array}{l}\text { Silver, decorated gilded } \\
\text { silver foil shield brooch. } \\
\text { The foil with laurel } \\
\text { wreath motif (under } \\
\text { layer). The results of } \\
\text { analysis other parts, see } \\
\text { Table 1:1-2. }\end{array}$ & $\begin{array}{c}208 \\
(803) \\
\text { stadium } \\
\text { IIIA/IIIB }\end{array}$ & 15530,03 & 97,28 & 0,32 & 0,65 & 0,35 & 0,38 & 0,08 & 0,19 & 0,1 & 0,12 & 0 & 0 & 0,35 & 0,18 & 0 & $\begin{array}{l}\text { Natuniewicz- } \\
\text { Sekuła, Okulicz- } \\
\text { Kozaryn 2011, } \\
\text { 65-66, pl. } \\
\text { LXXXIII:1 }\end{array}$ \\
\hline 14 & $\begin{array}{l}\text { Iron crest-headed brooch, } \\
\text { decorated silver foil. } \\
\text { Type A.V.126. The foil } \\
\text { from lower part of bow. }\end{array}$ & $\begin{array}{c}467 \\
(2377) \\
\text { stadium } \\
\text { IIIA/IIIB } \\
\end{array}$ & 15538 & 98,6 & 0,28 & 0,21 & 0,06 & 0 & 0,06 & 0,33 & 0,06 & 0,1 & 0,06 & 0 & 0,24 & 0 & 0 & \begin{tabular}{|l|} 
Natuniewicz- \\
Sekuła, Okulicz- \\
Kozaryn 2011, \\
116, pl. CCVII:3 \\
\end{tabular} \\
\hline 15 & $\begin{array}{l}\text { Iron crest-headed brooch, } \\
\text { decorated silver foil. } \\
\text { Type close to A.V.126 } \\
\text { with features A.V.130. } \\
\text { Foil from the crest on the } \\
\text { head. }\end{array}$ & $\begin{array}{c}22 \\
(102) \\
\text { stadium IIB/IIC }\end{array}$ & 15539 & 94,19 & 4,24 & 0,17 & 0,06 & 0,12 & 0,05 & 0,4 & 0,08 & 0,28 & 0 & 0 & 0 & 0,4 & 0 & $\begin{array}{l}\text { Natuniewicz- } \\
\text { Sekuła, Okulicz- } \\
\text { Kozaryn 2011, 29, } \\
\text { pl. VII:22/1 }\end{array}$ \\
\hline 16 & $\begin{array}{l}\text { Iron crest-headed brooch, } \\
\text { decorated silver foil. } \\
\text { Type close to A.V.126 } \\
\text { and A.V.130. The foil } \\
\text { from the bow. }\end{array}$ & $\begin{array}{c}22 \\
(102) \\
\text { stadium IIB/IIC }\end{array}$ & 15539,01 & 97,31 & 1,6 & 0,29 & 0,08 & 0,01 & 0,04 & 0,24 & 0 & 0 & 0,02 & 0 & 0,36 & 0,05 & 0 & $\begin{array}{l}\text { Natuniewicz- } \\
\text { Sekuła, Okulicz- } \\
\text { Kozaryn 2011, 29, } \\
\text { pl. VII:22/1 }\end{array}$ \\
\hline
\end{tabular}




\begin{tabular}{|c|c|c|c|c|c|c|c|c|c|c|c|c|c|c|c|c|c|c|}
\hline 17 & \begin{tabular}{|l|} 
Iron brooch, decorated \\
silver, gilded silver foil \\
and filigree and \\
granulation. Type close \\
to A.V, series 1 . The foil \\
strip on crest of the bow. \\
The results of analysis \\
other parts, see Table \\
1:10. \\
\end{tabular} & $\begin{array}{c}26 \mathrm{~B} \\
(122) \\
\text { stadium IIB/IIC }\end{array}$ & 15540 & 97,38 & 0,37 & 0,24 & 0,13 & 0,09 & 0,06 & 0,32 & 0,09 & 0,11 & 0,04 & 0 & 0,86 & 0,26 & 0,07 & \begin{tabular}{|l|} 
Natuniewicz- \\
Sekuła, Okulicz- \\
Kozaryn 2011, 30, \\
pl. X:1.1a. \\
Fig. 2:3
\end{tabular} \\
\hline 18 & $\begin{array}{l}\text { Silver Schlangenkopf } \\
\text { bracelet. Type close to } \\
\text { Wójcik IVB. From the } \\
\text { bow. }\end{array}$ & $\begin{array}{c}210 \text { stadium IIIB } \\
(832)\end{array}$ & 15541 & 91,93 & 6,48 & 0,41 & 0,05 & 0,04 & 0,17 & 0,2 & 0,03 & 0 & 0,08 & 0 & 0 & 0,6 & 0 & \begin{tabular}{|l|} 
Natuniewicz- \\
Sekuła, Okulicz- \\
Kozaryn 2011, 67, \\
pl. LXXXVI:4 \\
\end{tabular} \\
\hline 19 & $\begin{array}{l}\text { Silver Schlangenkopf } \\
\text { bracelet. Type Wójcik V. } \\
\text { From the bow. }\end{array}$ & $\begin{array}{c}452 \\
(2278) \\
\text { stadium IIIB }\end{array}$ & 15542 & 97,25 & 1,56 & 0,41 & 0,1 & 0,03 & 0,03 & 0,16 & 0 & 0 & 0 & 0 & 0,16 & 0,3 & 0 & \begin{tabular}{|l|} 
Natuniewicz- \\
Sekuła, Okulicz- \\
Kozaryn 2011, \\
113, pl. CXCIX:5 \\
\end{tabular} \\
\hline 20 & $\begin{array}{l}\text { Silver Schlangenkopf } \\
\text { bracelet. Type Wójcik V. } \\
\text { From the head. }\end{array}$ & $\begin{array}{c}452 \\
(2281) \\
\text { stadium IIIB }\end{array}$ & 15543 & 97,33 & 1,69 & 0,58 & 0,17 & 0 & 0,05 & 0,11 & 0,01 & 0,05 & 0 & 0 & 0 & 0 & 0 & \begin{tabular}{|l|} 
Natuniewicz- \\
Sekuła, Okulicz- \\
Kozaryn 2011, \\
113, pl. CXCIX:6 \\
\end{tabular} \\
\hline 21 & $\begin{array}{l}\text { Brass crest-headed } \\
\text { brooch with cylinder for } \\
\text { the spring, decorated } \\
\text { silver foil. Type with } \\
\text { features to A.V.126 and } \\
\text { A.V.130. The foil from } \\
\text { the crest on the head. The } \\
\text { results of analysis other } \\
\text { parts, see Table 3:7-8. } \\
\end{array}$ & $\begin{array}{c}386 \\
(1943) \\
\text { stadium IIB/IIC }\end{array}$ & 15545 & 95,66 & 1,16 & 0,3 & 0,12 & 0,02 & 0,03 & 0,19 & 0 & 0 & 0 & 0 & 0,43 & 2,09 & 0 & $\begin{array}{l}\text { Natuniewicz- } \\
\text { Sekuła, Okulicz- } \\
\text { Kozaryn 2011, } \\
\text { 101, pl. } \\
\text { CLXVIII:386/1. } \\
\text { Fig. 8:1 }\end{array}$ \\
\hline 22 & $\begin{array}{l}\text { Silver spring-cover } \\
\text { brooch. Type A.II.40-41. } \\
\text { The underside of the bow } \\
\text { by the catchplate. }\end{array}$ & $\begin{array}{c}452 \\
(2276) \\
\text { stadium IIIB }\end{array}$ & 15546 & 97,29 & 1,94 & 0,2 & 0,12 & 0,03 & 0,11 & 0,16 & 0,01 & 0 & 0 & 0 & 0,14 & 0 & 0 & \begin{tabular}{|l} 
Natuniewicz- \\
Sekuła, Okulicz- \\
Kozaryn 2011, \\
112, pl. \\
CXCVIII:2 \\
\end{tabular} \\
\hline 23 & $\begin{array}{l}\text { Silver spring-cover } \\
\text { brooch. Type A.II.40-41. } \\
\text { The underside of the bow } \\
\text { by the catchplate. }\end{array}$ & $\begin{array}{c}452 \\
(2286) \\
\text { stadium IIIB }\end{array}$ & 15547 & 97,36 & 2,14 & 0,2 & 0,03 & 0,02 & 0,04 & 0,14 & 0 & 0 & 0 & 0 & 0,07 & 0 & 0 & $\begin{array}{l}\text { Natuniewicz- } \\
\text { Sekuła, Okulicz- } \\
\text { Kozaryn 2011, } \\
\text { 112, pl. } \\
\text { CXCVIII:1 }\end{array}$ \\
\hline 24 & $\begin{array}{l}\text { Silver Schlangenkopf } \\
\text { bracelet. Type Wójcik } \\
\text { IVB. From the bow. }\end{array}$ & $\begin{array}{c}210 \\
(833) \\
\text { stadium IIIB }\end{array}$ & 15548 & 97,83 & 1,17 & 0,38 & 0,18 & 0,01 & 0,08 & 0,17 & 0 & 0,08 & 0 & 0 & 0,11 & 0 & 0 & \begin{tabular}{|l|} 
Natuniewicz- \\
Sekuła, Okulicz- \\
Kozaryn 2011, 67, \\
pl. LXXXVI:3
\end{tabular} \\
\hline
\end{tabular}




\begin{tabular}{|c|c|c|c|c|c|c|c|c|c|c|c|c|c|c|c|c|c|c|}
\hline 25 & $\begin{array}{l}\text { Silver Schlangenkopf } \\
\text { bracelet. Type Wójcik } \\
\text { IVB. From the gorget of } \\
\text { the head. }\end{array}$ & $\begin{array}{c}210 \\
(833) \\
\text { stadium IIIB }\end{array}$ & 15548,01 & 95,55 & 2,46 & 0,39 & 0,27 & 0 & 0 & 0,88 & 0 & 0 & 0 & 0 & 0,2 & 0,25 & 0 & \begin{tabular}{|l} 
Natuniewicz- \\
Sekuła, Okulicz- \\
Kozaryn 2011, 67, \\
pl. LXXXVI:3 \\
\end{tabular} \\
\hline 26 & $\begin{array}{l}\text { Silver S-shape clasp. } \\
\text { Type von Müller B. The } \\
\text { beaded wire from the } \\
\text { base. }\end{array}$ & $\begin{array}{c}210 \\
(817) \\
\text { stadium IIIB }\end{array}$ & 15549 & 96,87 & 1,27 & 0,33 & 0,24 & 0,09 & 0,07 & 0,16 & 0 & 0,02 & 0 & 0 & 0,84 & 0,1 & 0 & \begin{tabular}{|l} 
Natuniewicz- \\
Sekuła, Okulicz- \\
Kozaryn 2011, 67, \\
pl. LXXXVI:7 \\
\end{tabular} \\
\hline 27 & $\begin{array}{l}\text { Silver crossbow tendril } \\
\text { brooch, with triple rings } \\
\text { of beaded wire. Type } \\
\text { A.VI.167. From the foot. }\end{array}$ & $\begin{array}{c}389 \\
(1945) \\
\text { stadium IVB }\end{array}$ & 15550 & 95,07 & 4,01 & 0,29 & 0,05 & 0 & 0,01 & 0,21 & 0 & 0,13 & 0 & 0 & 0 & 0,22 & 0 & \begin{tabular}{|l|} 
Natuniewicz- \\
Sekuła, Okulicz- \\
Kozaryn 2011, \\
102, pl. \\
CLXXIII:3 \\
\end{tabular} \\
\hline 28 & $\begin{array}{l}\text { Silver crossbow tendril } \\
\text { brooch, with triple rings } \\
\text { of beaded wire. Type } \\
\text { A.VI.167. Beaded wire } \\
\text { from the central ring on } \\
\text { the head knob. } \\
\end{array}$ & $\begin{array}{c}389 \\
(1945) \\
\text { stadium IVB }\end{array}$ & 15550,01 & 95,31 & 2,81 & 0,23 & 0,07 & 0 & 0,09 & 0,27 & 0,09 & 0,23 & 0,01 & 0 & 0,19 & 0,7 & 0 & \begin{tabular}{|l} 
Natuniewicz- \\
Sekuła, Okulicz- \\
Kozaryn 2011, \\
102, pl. \\
CLXXIII:3 \\
\end{tabular} \\
\hline 29 & \begin{tabular}{|l|} 
Brass lunula pendant \\
decorated silver gilded \\
foil. The bottom layer of \\
the foil. The results of \\
analysis other parts, see \\
Table 1:11. \\
\end{tabular} & $\begin{array}{c}275 \\
(1222) \\
\text { stadium V }\end{array}$ & 15551 & 94,77 & 1,33 & 0,27 & 0,1 & 0 & 0,07 & 0,2 & 0,11 & 0,05 & 0 & 0 & 2,8 & 0,27 & 0 & $\begin{array}{l}\text { Natuniewicz- } \\
\text { Sekuła, Okulicz- } \\
\text { Kozaryn 2011, 80, } \\
\text { pl. CXVII:9. Fig. } \\
\text { 2:1 }\end{array}$ \\
\hline 30 & $\begin{array}{l}\text { Silver crossbow tendril } \\
\text { brooch with false spring. } \\
\text { Type A.VI.168. From the } \\
\text { foot. }\end{array}$ & $\begin{array}{c}275 \\
(1227) \\
\text { stadium V }\end{array}$ & $15552 \mathrm{~A}$ & 95,95 & 2,22 & 0,41 & 0,16 & 0,02 & 0,11 & 0,15 & 0 & 0,47 & 0 & 0 & 0,5 & 0,01 & 0 & $\begin{array}{l}\text { Natuniewicz- } \\
\text { Sekuła, Okulicz- } \\
\text { Kozaryn 2011, 80, } \\
\text { pl. CXVI:1 } \\
\end{array}$ \\
\hline 31 & \begin{tabular}{|l|} 
Silver crossbow brooch \\
with closed catchplate, \\
decorated silver gilded \\
foil. Type close to \\
A.VI.170. From the foot. \\
The results of analysis \\
other parts, see Table \\
$1: 12 ; 4: 2$. \\
\end{tabular} & $\begin{array}{c}275 \\
(1247) \\
\text { stadium V }\end{array}$ & 15552 & 93,87 & 4,46 & 0,57 & 0,15 & 0,03 & 0,15 & 0,15 & 0,01 & 0,37 & 0 & 0 & 0 & 0,23 & 0 & $\begin{array}{l}\text { Natuniewicz- } \\
\text { Sekuła, Okulicz- } \\
\text { Kozaryn 2011, 80, } \\
\text { pl. CXVI:3. Fig. } \\
\text { 2:2, 4:6 }\end{array}$ \\
\hline 32 & \begin{tabular}{|l|} 
Silver crossbow tendril \\
brooch, decorated silver \\
gilded foil. Type \\
A.VI.162. The lower part \\
of the bow. The results of \\
analysis other parts, see \\
Table 1:13. \\
\end{tabular} & $\begin{array}{c}150 \\
(605) \\
\text { stadium } \\
\text { IVA/IVB }\end{array}$ & 15554 & 97,86 & 1,31 & 0,38 & 0,04 & 0,08 & 0,08 & 0,18 & 0 & 0,06 & 0 & 0 & 0 & 0 & 0 & $\begin{array}{l}\text { Natuniewicz- } \\
\text { Sekuła, Okulicz- } \\
\text { Kozaryn 2011, 55, } \\
\text { pl. LVIII:1 }\end{array}$ \\
\hline
\end{tabular}




\begin{tabular}{|c|c|c|c|c|c|c|c|c|c|c|c|c|c|c|c|c|c|c|}
\hline 33 & $\begin{array}{l}\text { Silver crossbow tendril } \\
\text { brooch, decorated silver } \\
\text { gilded foil. Type } \\
\text { A.VI.162. From the } \\
\text { chord of the spring. The } \\
\text { results of analysis other } \\
\text { parts, see Table 1:13. }\end{array}$ & $\begin{array}{c}150 \\
(605) \\
\text { stadium } \\
\text { IVA/IVB }\end{array}$ & 15554,01 & 96,49 & 1,78 & 0,36 & 0,13 & 0,01 & 0 & 0,23 & 0,07 & 0 & 0 & 0 & 0,14 & 0,8 & 0 & $\begin{array}{l}\text { Natuniewicz- } \\
\text { Sekuła, Okulicz- } \\
\text { Kozaryn 2011, 55, } \\
\text { pl. LVIII:1 }\end{array}$ \\
\hline 34 & $\begin{array}{l}\text { Silver crossbow brooch } \\
\text { with high catchplate, so } \\
\text { called Rosettenfibeln, } \\
\text { decorated gold foil, } \\
\text { knobs made of brass. } \\
\text { Type close to A. VII, } \\
\text { series } 4 \text {. Group } 6 \text { after } \\
\text { Lund Hansen, Przybyła. } \\
\text { The pin of a brooch. The } \\
\text { results of analysis other } \\
\text { parts, see Table 1:14-15. }\end{array}$ & $\begin{array}{c}150 \\
(606) \\
\text { stadium } \\
\text { IVA/IVB }\end{array}$ & 15555 & 94,95 & 1,88 & 0,19 & 0,08 & 0,01 & 0,04 & 0,14 & 0,02 & 1,79 & 0 & 0 & 0 & 0,89 & 0 & $\begin{array}{l}\text { Natuniewicz- } \\
\text { Sekuła, Okulicz- } \\
\text { Kozaryn 2011, } \\
\text { 55-56, pl. LX:3 }\end{array}$ \\
\hline 35 & $\begin{array}{l}\text { Silver crossbow brooch } \\
\text { with high catchplate, so } \\
\text { called Rosettenfibeln, } \\
\text { decorated gold foil, } \\
\text { knobs made of brass. } \\
\text { Type close to A. VII, } \\
\text { series 4. Group } 6 \text { after } \\
\text { Lund Hansen, Przybyła. } \\
\text { The bottom part of the } \\
\text { foot. The results of } \\
\text { analysis other parts, see } \\
\text { Table 1:14-15 } \\
\end{array}$ & $\begin{array}{c}150 \\
(606) \\
\text { stadium } \\
\text { IVA/IVB }\end{array}$ & 15555,01 & 95,06 & 2,71 & 0,26 & 0,11 & 0 & 0 & 0,16 & 0,08 & 1,26 & 0 & 0 & 0,09 & 0,26 & 0 & $\begin{array}{l}\text { Natuniewicz- } \\
\text { Sekuła, Okulicz- } \\
\text { Kozaryn 2011, } \\
\text { 55-56, pl. LX:3 }\end{array}$ \\
\hline 36 & $\begin{array}{l}\text { Silver crossbow brooch } \\
\text { with high catchplate, so } \\
\text { called Rosettenfibeln, } \\
\text { decorated gold foil, } \\
\text { knobs made of brass. } \\
\text { Type close to A. VII, } \\
\text { series 4. Group } 6 \text { after } \\
\text { Lund Hansen, Przybyła. } \\
\text { The bow of a brooch. } \\
\text { The results of analysis } \\
\text { other parts, see Table } \\
1: 16-17 ; 3: 10 .\end{array}$ & $\begin{array}{c}150 \\
(607) \\
\text { stadium } \\
\text { IVA/IVB }\end{array}$ & 15556 & 95,6 & 1,15 & 0,12 & 0,05 & 0,1 & 0,04 & 0,15 & 0 & 0,69 & 0 & 0 & 1,27 & 0,82 & 0 & $\begin{array}{l}\text { Natuniewicz- } \\
\text { Sekuła, Okulicz- } \\
\text { Kozaryn 2011, } \\
\text { 55-56, pl. LX:4 }\end{array}$ \\
\hline
\end{tabular}




\begin{tabular}{|c|c|c|c|c|c|c|c|c|c|c|c|c|c|c|c|c|c|c|}
\hline 37 & \begin{tabular}{|l|} 
Silver crossbow brooch \\
with high catchplate, so \\
called Rosettenfibeln, \\
decorated gold foil, \\
knobs made of brass. \\
Type close to A. VII, \\
series 4 . Group 6 after \\
Lund Hansen, Przybyła. \\
The bottom part of the \\
foot. The results of \\
analysis other parts, see \\
Table $1: 16-17 ; 3: 10$.
\end{tabular} & $\begin{array}{c}150 \\
(607) \\
\text { stadium } \\
\text { IVA/IVB }\end{array}$ & 15556,01 & 95,96 & 1,99 & 0,32 & 0,28 & 0 & 0 & 0,1 & 0,01 & 0,69 & 0,02 & 0 & 0 & 0,62 & 0 & $\begin{array}{l}\text { Natuniewicz- } \\
\text { Sekuła, Okulicz- } \\
\text { Kozaryn 2011, } \\
\text { 55-56, pl. LX:4 }\end{array}$ \\
\hline 38 & \begin{tabular}{|l|} 
Silver crossbow brooch \\
with high catchplate, so \\
called Rosettenfibeln, \\
decorated gold foil, \\
knobs made of brass. \\
Type close to A. VII, \\
series 4. Group 6 after \\
Lund Hansen, Przybyła. \\
The pin of a brooch. The \\
results of analysis other \\
parts, see Table 1:16-17; \\
3:10.
\end{tabular} & $\begin{array}{c}150 \\
(607) \\
\text { stadium } \\
\text { IVA/IVB }\end{array}$ & 15556,02 & 95,47 & 1,3 & 0,24 & 0,03 & 0,18 & 0,03 & 0,09 & 0,01 & 0,67 & 0 & 0 & 1,81 & 0,18 & 0 & $\begin{array}{l}\text { Natuniewicz- } \\
\text { Sekuła, Okulicz- } \\
\text { Kozaryn 2011, } \\
\text { 55-56, pl. LX:4 }\end{array}$ \\
\hline 39 & $\begin{array}{l}\text { Silver crossbow tendril } \\
\text { brooch with false spring. } \\
\text { Type A.VI.168. From the } \\
\text { foot. }\end{array}$ & $\begin{array}{c}288 \\
(1360) \\
\text { stadium V }\end{array}$ & 15557 & 97,02 & 1,92 & 0,27 & 0 & 0,03 & 0,09 & 0,21 & 0,03 & 0,07 & 0 & 0 & 0 & 0,37 & 0 & \begin{tabular}{|l|} 
Natuniewicz- \\
Sekuła, Okulicz- \\
Kozaryn 2011, 83, \\
pl. CXXVIII:2 \\
\end{tabular} \\
\hline 40 & $\begin{array}{l}\text { Silver crossbow tendril } \\
\text { brooch with false spring. } \\
\text { Type A.VI.168. From the } \\
\text { chord of the spring. }\end{array}$ & $\begin{array}{c}288 \\
(1360) \\
\text { stadium V }\end{array}$ & 15557,01 & 97,18 & 1,39 & 0,35 & 0,17 & 0 & 0,01 & 0,11 & 0 & 0,04 & 0 & 0 & 0,39 & 0,36 & 0 & \begin{tabular}{|l|} 
Natuniewicz- \\
Sekuła, Okulicz- \\
Kozaryn 2011, 83, \\
pl. CXXVIII:2 \\
\end{tabular} \\
\hline 41 & $\begin{array}{l}\text { Silver crossbow tendril } \\
\text { brooch with false spring. } \\
\text { Type A.VI.168. From the } \\
\text { bow. }\end{array}$ & $\begin{array}{c}288 \\
(1358) \\
\text { stadium V }\end{array}$ & 15558 & 94,27 & 2,78 & 0,28 & 0,12 & 0,06 & 0,04 & 0,28 & 0 & 0,48 & 0,11 & 0 & 0,66 & 0,91 & 0 & \begin{tabular}{|l|} 
Natuniewicz- \\
Sekuła, Okulicz- \\
Kozaryn 2011, 83, \\
pl. CXXVIII:3 \\
\end{tabular} \\
\hline 42 & $\begin{array}{l}\text { Silver crossbow tendril } \\
\text { brooch with false spring. } \\
\text { Type A.VI.168. From the } \\
\text { spring }\end{array}$ & $\begin{array}{c}288 \\
(1358) \\
\text { stadium V }\end{array}$ & 15558,01 & 96,87 & 1,24 & 0,34 & 0,33 & 0,05 & 0,01 & 0,2 & 0 & 0,48 & 0,01 & 0 & 0,2 & 0,27 & 0 & \begin{tabular}{|l|} 
Natuniewicz- \\
Sekuła, Okulicz- \\
Kozaryn 2011, 83, \\
pl. CXXVIII:3 \\
\end{tabular} \\
\hline 43 & $\begin{array}{l}\text { Silver crossbow tendril } \\
\text { brooch with closed } \\
\text { catchplate. Type } \\
\text { A.VI.170. From the bow. }\end{array}$ & $\begin{array}{c}288 \\
(1351) \\
\text { stadium V }\end{array}$ & 15559 & 97,08 & 2,24 & 0,35 & 0,12 & 0 & 0,05 & 0,16 & 0 & 0 & 0 & 0 & 0 & 0 & 0 & \begin{tabular}{|l|} 
Natuniewicz- \\
Sekuła, Okulicz- \\
Kozaryn 2011, 83, \\
pl. CXXVIII:1 \\
\end{tabular} \\
\hline
\end{tabular}




\begin{tabular}{|c|c|c|c|c|c|c|c|c|c|c|c|c|c|c|c|c|c|c|}
\hline 44 & $\begin{array}{l}\text { Silver crossbow tendril } \\
\text { brooch, decorated gold } \\
\text { foil. Type A.VI.162. } \\
\text { From the bottom of the } \\
\text { foot. The results of } \\
\text { analysis other parts, see } \\
\text { Table 1:18 }\end{array}$ & $\begin{array}{c}229 \\
(912) \\
\text { stadium IVA }\end{array}$ & 15560 & 96,4 & 2,35 & 0,37 & 0,12 & 0 & 0,12 & 0,16 & 0,05 & 0 & 0 & 0 & 0,07 & 0,36 & 0 & \begin{tabular}{|l|} 
Natuniewicz- \\
Sekuła, Okulicz- \\
Kozaryn 2011, 70, \\
pl. XCIV:229/1
\end{tabular} \\
\hline 45 & $\begin{array}{l}\text { Silver capsule pendant. } \\
\text { The underside shield of a } \\
\text { pendant. }\end{array}$ & $\begin{array}{c}413 \\
(2070) \\
\text { stadium IIB/IIC }\end{array}$ & 15561 & 96,25 & 2,21 & 0,29 & 0,11 & 0,17 & 0,02 & 0,14 & 0 & 0 & 0,21 & 0 & 0,16 & 0,43 & 0 & \begin{tabular}{|l|} 
Natuniewicz- \\
Sekuła, Okulicz- \\
Kozaryn 2011, \\
107, pl. \\
CLXXXVI:413/6 \\
\end{tabular} \\
\hline 46 & $\begin{array}{l}\text { Silver capsule pendant. } \\
\text { Beaded wire from the top } \\
\text { shield of pendant. }\end{array}$ & $\begin{array}{c}413 \\
(2070) \\
\text { stadium IIB/IIC }\end{array}$ & 15561,01 & 98,4 & 0,33 & 0,33 & 0,13 & 0,14 & 0,06 & 0,15 & 0,03 & 0,02 & 0 & 0 & 0 & 0,42 & 0 & \begin{tabular}{|l|} 
Natuniewicz- \\
Sekuła, Okulicz- \\
Kozaryn 2011, \\
107, pl. \\
CLXXXVI:413/6 \\
\end{tabular} \\
\hline 47 & $\begin{array}{l}\text { Silver capsule pendant. } \\
\text { The central granule on } \\
\text { the top shield. }\end{array}$ & $\begin{array}{c}413 \\
(2070) \\
\text { stadium IIB/IIC }\end{array}$ & 15561,02 & 97,61 & 0,32 & 0,37 & 0,23 & 0,33 & 0,06 & 0,25 & 0,09 & 0,15 & 0 & 0 & 0 & 0,59 & 0 & \begin{tabular}{|l|} 
Natuniewicz- \\
Sekuła, Okulicz- \\
Kozaryn 2011, \\
107, pl. \\
CLXXXVI:413/6 \\
\end{tabular} \\
\hline 48 & $\begin{array}{l}\text { Brass triple-crest brooch } \\
\text { and cylinder for the } \\
\text { spring, with traces of } \\
\text { silver foil on the } \\
\text { cylinder. Type A.V.96. } \\
\text { The foil from the } \\
\text { cylinder. The results of } \\
\text { analysis other parts, see } \\
\text { Table 3:9. }\end{array}$ & $\begin{array}{c}25 \\
(72) \\
\text { stadium IIB/IIC }\end{array}$ & 15562 & 83,42 & 0,61 & 0,25 & 0,17 & 0,06 & 0,03 & 0,21 & 0,05 & 0,06 & 0 & 0 & 15,16 & 0 & 0 & \begin{tabular}{|l|} 
Natuniewicz- \\
Sekuła, Okulicz- \\
Kozaryn 2011, 30, \\
pl. VII:1
\end{tabular} \\
\hline 49 & $\begin{array}{l}\text { Silver wellenförmige } \\
\text { bracelet. From the wire } \\
\text { of the hoop. }\end{array}$ & $\begin{array}{c}26 \mathrm{~B} \\
(120) \\
\text { stadium IIB/IIC }\end{array}$ & 15564 & 98,34 & 0,86 & 0,29 & 0,11 & 0,03 & 0,09 & 0,15 & 0,08 & 0,04 & 0 & 0 & 0 & 0 & 0 & \begin{tabular}{|l|} 
Natuniewicz- \\
Sekuła, Okulicz- \\
Kozaryn 2011, 31, \\
pl. XI:6 \\
\end{tabular} \\
\hline 50 & $\begin{array}{l}\text { Silver wellenförmige } \\
\text { bracelet. From the wire } \\
\text { of the hoop. }\end{array}$ & $\begin{array}{c}26 \mathrm{~B} \\
(125) \\
\text { stadium IIB/IIC }\end{array}$ & 15565 & 98,37 & 0,87 & 0,41 & 0,06 & 0,01 & 0 & 0,19 & 0,03 & 0,06 & 0 & 0 & 0 & 0 & 0 & \begin{tabular}{|l|} 
Natuniewicz- \\
Sekuła, Okulicz- \\
Kozaryn 2011, 31, \\
pl. XI:7
\end{tabular} \\
\hline 51 & \begin{tabular}{|l} 
Silver Schlangenkopf \\
bracelet. Type Wójcik \\
IIIA. From the bow \\
narrowness.
\end{tabular} & $\begin{array}{c}26 \mathrm{~B} \\
(124) \\
\text { stadium IIB/IIC }\end{array}$ & 15566 & 96,28 & 1,58 & 0,46 & 0 & 0,12 & 0,1 & 0,24 & 0,04 & 0,5 & 0 & 0 & 0 & 0,69 & 0 & \begin{tabular}{|l|} 
Natuniewicz- \\
Sekuła, Okulicz- \\
Kozaryn 2011, 31, \\
pl. XI:4. Fig. 3:2 \\
\end{tabular} \\
\hline
\end{tabular}




\begin{tabular}{|c|c|c|c|c|c|c|c|c|c|c|c|c|c|c|c|c|c|c|}
\hline 52 & $\begin{array}{l}\text { Silver Schlangenkopf } \\
\text { bracelet. Type Wójcik } \\
\text { IIIA. From the plaque } \\
\text { soldered on the head } \\
\text { gorget. }\end{array}$ & $\begin{array}{c}26 \mathrm{~B} \\
(119) \\
\text { stadium IIB/IIC }\end{array}$ & 15567 & 96,75 & 1,96 & 0,4 & 0,05 & 0,09 & 0 & 0,21 & 0,02 & 0,05 & 0 & 0 & 0,04 & 0,44 & 0 & $\begin{array}{l}\text { Natuniewicz- } \\
\text { Sekuła, Okulicz- } \\
\text { Kozaryn 2011, 31, } \\
\text { pl. XI:5 }\end{array}$ \\
\hline 53 & $\begin{array}{l}\text { Silver Schlangenkopf } \\
\text { bracelet. Type Wójcik } \\
\text { IIIA. From the bow. }\end{array}$ & $\begin{array}{c}26 \mathrm{~B} \\
(119) \\
\text { stadium IIB/IIC }\end{array}$ & 15567,01 & 93,55 & 5,26 & 0,29 & 0,08 & 0,07 & 0,1 & 0,19 & 0,02 & 0,36 & 0 & 0 & 0,03 & 0,06 & 0 & \begin{tabular}{|l} 
Natuniewicz- \\
Sekuła, Okulicz- \\
Kozaryn 2011, 31, \\
pl. XI:5
\end{tabular} \\
\hline 54 & $\begin{array}{l}\text { Silver Schlangenkopf } \\
\text { bracelet. Type Wójcik } \\
\text { IIIA. From the bow } \\
\text { narrowness. } \\
\end{array}$ & $\begin{array}{c}26 \mathrm{~B} \\
(119) \\
\text { stadium IIB/IIC }\end{array}$ & 15567,02 & 91,48 & 7,2 & 0,38 & 0,12 & 0,02 & 0,08 & 0,16 & 0 & 0,34 & 0 & 0 & 0,04 & 0,18 & 0 & \begin{tabular}{|l|} 
Natuniewicz- \\
Sekuła, Okulicz- \\
Kozaryn 2011, 31, \\
pl. XI:5 \\
\end{tabular} \\
\hline 55 & $\begin{array}{l}\text { Brass triple-crest } \\
\text { brooch, decorated silver } \\
\text { foil. Type A.V.96. The } \\
\text { foil from the head crest. } \\
\text { The results of analysis } \\
\text { other parts, see Table } \\
\text { 3:11. } \\
\end{array}$ & $\begin{array}{c}26 \mathrm{~B} \\
(123) \\
\text { stadium IIB/IIC }\end{array}$ & 15568 & 96,82 & 1,78 & 0,36 & 0,28 & 0,12 & 0 & 0,31 & 0 & 0,02 & 0 & 0 & 0,31 & 0 & 0 & $\begin{array}{l}\text { Natuniewicz- } \\
\text { Sekuła, Okulicz- } \\
\text { Kozaryn 2011, 31, } \\
\text { pl. XI:3-3a }\end{array}$ \\
\hline 56 & $\begin{array}{l}\text { Brass brooch with } \\
\text { cylinder for the spring } \\
\text { and crest on the head and } \\
\text { foot terminal, decorated } \\
\text { silver foil. Type with } \\
\text { features A.V, series } 1 \\
\text { and A.V, series } 8 \text {. The } \\
\text { foil from bow. The } \\
\text { results of analysis other } \\
\text { parts, see Table 3:14. }\end{array}$ & $\begin{array}{c}402 \\
(2009) \\
\text { stadium } \\
\text { IIIA/IIIB }\end{array}$ & 15571 & 96,46 & 0,81 & 0,41 & 0,44 & 0 & 0,08 & 0,21 & 0,11 & 0,08 & 0 & 0 & 1,22 & 0,18 & 0 & $\begin{array}{l}\text { Natuniewicz- } \\
\text { Sekuła, Okulicz- } \\
\text { Kozaryn 2011, } \\
\text { 104, pl. } \\
\text { CLXXXI:3 }\end{array}$ \\
\hline 57 & $\begin{array}{l}\text { Silver Schlangenkopf } \\
\text { bracelet. Type Wójcik } \\
\text { IIIA. From the bow } \\
\text { narrowness. }\end{array}$ & $\begin{array}{c}402 \\
(2017) \\
\text { stadium } \\
\text { IIIA/IIIB }\end{array}$ & 15572 & 96,4 & 2,8 & 0,24 & 0,01 & 0,01 & 0,01 & 0,16 & 0,09 & 0,29 & 0 & 0 & 0 & 0 & 0 & $\begin{array}{l}\text { Natuniewicz- } \\
\text { Sekuła, Okulicz- } \\
\text { Kozaryn 2011, } \\
\text { 104, pl. } \\
\text { CLXXXI:4 }\end{array}$ \\
\hline 58 & $\begin{array}{l}\text { Silver Schlangenkopf } \\
\text { bracelet. Type Wójcik } \\
\text { IIIA. From the bow } \\
\text { narrowness. }\end{array}$ & $\begin{array}{c}402 \\
(2018) \\
\text { stadium } \\
\text { IIIA/IIIB }\end{array}$ & 15573 & 96,1 & 2,59 & 0,27 & 0,07 & 0,02 & 0,08 & 0,16 & 0,03 & 0,28 & 0,04 & 0 & 0,17 & 0,18 & 0 & $\begin{array}{l}\text { Natuniewicz- } \\
\text { Sekuła, Okulicz- } \\
\text { Kozaryn 2011, } \\
\text { 104, pl. } \\
\text { CLXXXI:5 }\end{array}$ \\
\hline 59 & $\begin{array}{l}\text { Silver crest-headed } \\
\text { brooch, decorated } \\
\text { composition of filigree. } \\
\text { Type A.V.126. From the } \\
\text { bow. }\end{array}$ & $\begin{array}{c}432 \\
(2206) \\
\text { stadium IIIA }\end{array}$ & 15575 & 90,87 & 2,17 & 0,57 & 0,92 & 0,06 & 0,04 & 0,3 & 0,01 & 0,35 & 0 & 4,66 & 0 & 0 & 0,07 & \begin{tabular}{|l} 
Natuniewicz- \\
Sekuła, Okulicz- \\
Kozaryn 2011, \\
109, pl. \\
CXCIII:432/1. \\
Fig. 3:4 \\
\end{tabular} \\
\hline
\end{tabular}




\begin{tabular}{|c|c|c|c|c|c|c|c|c|c|c|c|c|c|c|c|c|c|c|}
\hline 60 & $\begin{array}{l}\text { Silver crest-headed } \\
\text { brooch, decorated } \\
\text { composition of filigree. } \\
\text { Type A.V.126. From the } \\
\text { bow. }\end{array}$ & $\begin{array}{c}432 \\
(2206) \\
\text { stadium IIIA }\end{array}$ & 15575,01 & 90,87 & 2,17 & 0,57 & 0,92 & 0,06 & 0,04 & 0,3 & 0,01 & 0,35 & 0 & 4,65 & 0 & 0,08 & 0 & \begin{tabular}{|l|} 
Natuniewicz- \\
Sekuła, Okulicz- \\
Kozaryn 2011, \\
109, pl. \\
CXCIII:432/1. \\
Fig. 3:4 \\
\end{tabular} \\
\hline 61 & $\begin{array}{l}\text { Silver crest-headed } \\
\text { brooch, decorated } \\
\text { composition of filigree. } \\
\text { Type A.V.126. From the } \\
\text { bow. }\end{array}$ & $\begin{array}{c}432 \\
(2206) \\
\text { stadium IIIA }\end{array}$ & 15575,02 & 90,63 & 2,73 & 0,25 & 0,18 & 0 & 0,05 & 0,27 & 0 & 0,4 & 0 & 5,36 & 0,13 & 0 & 0 & \begin{tabular}{|l} 
Natuniewicz- \\
Sekuła, Okulicz- \\
Kozaryn 2011, \\
109, pl. \\
CXCIII:432/1. \\
Fig. 3:4
\end{tabular} \\
\hline 62 & $\begin{array}{l}\text { Silver crest-headed } \\
\text { brooch, decorated } \\
\text { composition of filigree. } \\
\text { Type A.V.126. From the } \\
\text { chord of a spring. }\end{array}$ & $\begin{array}{c}432 \\
(2206) \\
\text { stadium IIIA }\end{array}$ & 15575,03 & 96,13 & 1,62 & 0,37 & 0,22 & 0,02 & 0,05 & 0,21 & 0 & 0,03 & 0,16 & 0 & 0,37 & 0,36 & 0,46 & \begin{tabular}{|l} 
Natuniewicz- \\
Sekuła, Okulicz- \\
Kozaryn 2011, \\
109, pl. \\
CXCIII:432/1. \\
Fig. 3:4 \\
\end{tabular} \\
\hline 63 & $\begin{array}{l}\text { Silver crest-headed } \\
\text { brooch, decorated } \\
\text { composition of filigree. } \\
\text { Type A.V.126. From the } \\
\text { foot. }\end{array}$ & $\begin{array}{c}432 \\
(2206) \\
\text { stadium IIIA }\end{array}$ & 15575,04 & 94,89 & 3,25 & 0,27 & 0,09 & 0 & 0,03 & 0,26 & 0 & 0,49 & 0 & 0,72 & 0 & 0 & 0 & \begin{tabular}{|l} 
Natuniewicz- \\
Sekuła, Okulicz- \\
Kozaryn 2011, \\
109, pl. \\
CXCIII:432/1. \\
Fig. 3:4 \\
\end{tabular} \\
\hline 64 & $\begin{array}{l}\text { Silver crest-headed } \\
\text { brooch, decorated } \\
\text { composition of filigree. } \\
\text { Type A.V.126. From the } \\
\text { filigree on a crest. }\end{array}$ & $\begin{array}{c}432 \\
(2206) \\
\text { stadium IIIA }\end{array}$ & 15575,05 & 98,13 & 0,67 & 0,33 & 0,17 & 0,08 & 0 & 0,21 & 0,02 & 0,02 & 0 & 0 & 0,35 & 0,02 & 0 & $\begin{array}{l}\text { Natuniewicz- } \\
\text { Sekuła, Okulicz- } \\
\text { Kozaryn 2011, } \\
\text { 109, pl. } \\
\text { CXCIII:432/1. } \\
\text { Fig. 3:4 } \\
\end{array}$ \\
\hline 65 & $\begin{array}{l}\text { Brass brooch with } \\
\text { cylinder for the spring, } \\
\text { crest on the head and } \\
\text { circular disc on the foot, } \\
\text { decorated silver foil, } \\
\text { filigree and granulation. } \\
\text { Type with features A.V, } \\
\text { series } 1 \text { and A.V, series } \\
\text { 8. The central granule } \\
\text { from the bow bend. The } \\
\text { results of analysis other } \\
\text { parts, see Table 3:15. }\end{array}$ & $\begin{array}{c}252 \\
(1059) \\
\text { stadium IIIB }\end{array}$ & 15576 & 95,04 & 1,63 & 0,36 & 0,58 & 0,04 & 0,08 & 0,15 & 0 & 0 & 0 & 0,9 & 0,43 & 0,72 & 0,06 & $\begin{array}{l}\text { Natuniewicz- } \\
\text { Sekuła, Okulicz- } \\
\text { Kozaryn 2011, 75, } \\
\text { pl. CI:252/3. Fig. } \\
\text { 3:3 }\end{array}$ \\
\hline
\end{tabular}




\begin{tabular}{|c|c|c|c|c|c|c|c|c|c|c|c|c|c|c|c|c|c|c|}
\hline 66 & $\begin{array}{l}\text { Brass brooch with } \\
\text { cylinder for the spring, } \\
\text { crest on the head and } \\
\text { circular disc on the foot, } \\
\text { decorated silver foil, } \\
\text { filigree and granulation. } \\
\text { Type with features to } \\
\text { A.V, series } 1 \text { and A.V, } \\
\text { series } 8 \text {. The foil from } \\
\text { the lower part of a bow. } \\
\text { The results of analysis } \\
\text { other parts, see Table } \\
\text { 3:15. } \\
\end{array}$ & $\begin{array}{c}252 \\
(1059) \\
\text { stadium IIIB }\end{array}$ & 15576,01 & 97,69 & 0,98 & 0,35 & 0,25 & 0,02 & 0,01 & 0,2 & 0,03 & 0,01 & 0 & 0 & 0,34 & 0,1 & 0 & \begin{tabular}{|l|} 
Natuniewicz- \\
Sekuła, Okulicz- \\
Kozaryn 2011, 75, \\
pl. CI:252/3. Fig. \\
3:3
\end{tabular} \\
\hline 67 & $\begin{array}{l}\text { Silver crossbow tendril } \\
\text { brooch with triple rings } \\
\text { of beaded wire. Type } \\
\text { close to A.VI.167. From } \\
\text { the top side of the foot. } \\
\end{array}$ & $\begin{array}{c}34 \\
(128) \\
\text { stadium V }\end{array}$ & 15577 & 95,77 & 3,63 & 0,22 & 0,06 & 0,05 & 0,05 & 0,21 & 0 & 0 & 0 & 0 & 0 & 0 & 0 & \begin{tabular}{|l|} 
Natuniewicz- \\
Sekuła, Okulicz- \\
Kozaryn 2011, 33, \\
pl. XV:3
\end{tabular} \\
\hline 68 & \begin{tabular}{|l|} 
Silver crossbow tendril \\
brooch with triple rings \\
of beaded wire. Type \\
close to A.VI.167. \\
Beaded wire from central \\
ring from the head.
\end{tabular} & $\begin{array}{c}34 \\
(128) \\
\text { stadium V }\end{array}$ & 15577,01 & 94,61 & 2,59 & 0,31 & 0,15 & 0,1 & 0,01 & 0,21 & 0,01 & 0 & 0 & 0 & 0,03 & 1,55 & 0,43 & \begin{tabular}{|l|} 
Natuniewicz- \\
Sekuła, Okulicz- \\
Kozaryn 2011, 33, \\
pl. XV:3
\end{tabular} \\
\hline 69 & \begin{tabular}{|l|} 
Silver spring-cover \\
brooch. Type A.II.40-41. \\
The underside of the bow \\
by the catchplate.
\end{tabular} & $\begin{array}{c}342 \\
(1703) \\
\text { stadium IIIB }\end{array}$ & 15579 & 96,93 & 2,02 & 0,36 & 0,09 & 0,03 & 0,03 & 0,15 & 0 & 0,08 & 0 & 0 & 0,25 & 0,05 & 0 & \begin{tabular}{|l|} 
Natuniewicz- \\
Sekuła, Okulicz- \\
Kozaryn 2011, 93, \\
pl. CXLIX:1. Fig. \\
4:1 \\
\end{tabular} \\
\hline 70 & \begin{tabular}{|l|} 
Silver spring-cover \\
brooch. Type A.II.40-41. \\
The underside of the bow \\
by the catchplate.
\end{tabular} & $\begin{array}{c}342 \\
(1704) \\
\text { stadium IIIB }\end{array}$ & 15580 & 96,9 & 2,02 & 0,29 & 0,11 & 0,03 & 0,04 & 0,15 & 0 & 0,04 & 0,11 & 0 & 0,19 & 0,14 & 0 & \begin{tabular}{|l|} 
Natuniewicz- \\
Sekuła, Okulicz- \\
Kozaryn 2011, 93, \\
pl. CXLIX:2 \\
\end{tabular} \\
\hline 71 & $\begin{array}{l}\text { Silver capsule pendant. } \\
\text { The underside shield of } \\
\text { the capsule. }\end{array}$ & $\begin{array}{c}250 \\
(1050) \\
\text { stadium } \\
\text { IIIA/IIIB } \\
\end{array}$ & 15581 & 96,14 & 1,17 & 0,83 & 0,29 & 0 & 0,16 & 0,25 & 0,11 & 0,21 & 0 & 0 & 0,08 & 0,75 & 0 & \begin{tabular}{|l|} 
Natuniewicz- \\
Sekuła, Okulicz- \\
Kozaryn 2011, 74, \\
pl. C:250/7 \\
\end{tabular} \\
\hline 72 & $\begin{array}{l}\text { Silver capsule pendant. } \\
\text { The underside shield of } \\
\text { the capsule. }\end{array}$ & $\begin{array}{c}25 \\
(81) \\
\text { stadium IIB/IIC }\end{array}$ & 15582 & 96,33 & 2,37 & 0,32 & 0,09 & 0,09 & 0,04 & 0,13 & 0 & 0,07 & 0,11 & 0 & 0,19 & 0,25 & 0 & \begin{tabular}{|l|} 
Natuniewicz- \\
Sekuła, Okulicz- \\
Kozaryn 2011,30, \\
pl. VII:9 \\
\end{tabular} \\
\hline 73 & $\begin{array}{l}\text { Silver capsule pendant. } \\
\text { beaded wire on top shield } \\
\text { of the capsule. }\end{array}$ & $\begin{array}{c}25 \\
(81) \\
\text { stadium IIB/IIC }\end{array}$ & 15582,01 & 98,23 & 0,34 & 0,36 & 0,08 & 0,1 & 0 & 0,16 & 0,12 & 0,09 & 0 & 0 & 0 & 0,51 & 0 & \begin{tabular}{|l|} 
Natuniewicz- \\
Sekuła, Okulicz- \\
Kozaryn 2011,30, \\
pl. VII:9 \\
\end{tabular} \\
\hline
\end{tabular}




\begin{tabular}{|c|c|c|c|c|c|c|c|c|c|c|c|c|c|c|c|c|c|c|}
\hline 74 & $\begin{array}{l}\text { Silver lunula pendant. } \\
\text { From the central part. }\end{array}$ & $\begin{array}{c}256 \\
(1076) \\
\text { stadium IIIB }\end{array}$ & 15584 & 96,05 & 1,83 & 0,44 & 0,18 & 0 & 0,08 & 0,23 & 0,04 & 0,03 & 0 & 0 & 0,17 & 0,97 & 0 & \begin{tabular}{|l|} 
Natuniewicz- \\
Sekuła, Okulicz- \\
Kozaryn 2011, 76, \\
pl. CVII:5 \\
\end{tabular} \\
\hline 75 & $\begin{array}{l}\text { Silver lunula pendant. } \\
\text { From the central part. }\end{array}$ & $\begin{array}{c}256 \\
(1075) \\
\text { stadium IIIB }\end{array}$ & 15585 & 96,45 & 1,46 & 0,41 & 0,03 & 0,06 & 0,04 & 0,14 & 0 & 0 & 0 & 0 & 0,27 & 1,14 & 0 & \begin{tabular}{|l|} 
Natuniewicz- \\
Sekuła, Okulicz- \\
Kozaryn 2011, 76, \\
pl. CVII:7
\end{tabular} \\
\hline 76 & $\begin{array}{l}\text { Silver brooch with high } \\
\text { catchplate and upper } \\
\text { chord. Type A.VII, series } \\
\text { 1. From the bow. }\end{array}$ & $\begin{array}{c}256 \\
(1077) \\
\text { stadium IIIB }\end{array}$ & 15586 & 96,35 & 1,56 & 0,44 & 0,59 & 0 & 0,07 & 0,17 & 0 & 0,04 & 0 & 0 & 0,35 & 0,43 & 0 & \begin{tabular}{|l|} 
Natuniewicz- \\
Sekuła, Okulicz- \\
Kozaryn 2011, 76, \\
pl. CVII:3 \\
\end{tabular} \\
\hline 77 & \begin{tabular}{|l|} 
Silver brooch with high \\
catchplate and upper \\
chord. Type A.VII, series \\
1. The pin of a brooch. \\
\end{tabular} & $\begin{array}{c}256 \\
(1077) \\
\text { stadium IIIB }\end{array}$ & 15586,01 & 96,08 & 2,15 & 0,41 & 0,12 & 0 & 0,08 & 0,11 & 0,05 & 0,15 & 0,04 & 0 & 0,23 & 0,58 & 0 & \begin{tabular}{|l|} 
Natuniewicz- \\
Sekuła, Okulicz- \\
Kozaryn 2011, 76, \\
pl. CVII:3 \\
\end{tabular} \\
\hline 78 & \begin{tabular}{|l|} 
Silver and brass (tongue \\
on the catchplate) brooch \\
with high catchplate, so \\
called Rosettenfibeln, \\
decorated silver gilded \\
foil. Lubieszewo, Nowy \\
Dwór Gdański district. \\
Type close to A. VII, \\
series 4. Group 6 after \\
Lund Hansen, Przybyła. \\
The pin of the brooch. \\
The results of analysis \\
other parts, see Table \\
$1: 26-28 ; 3: 16 ; 4: 3$. \\
\end{tabular} & $\begin{array}{c}10 \\
\text { (collections of } \\
\text { the Museum of } \\
\text { Archaeology and } \\
\text { History in } \\
\text { Elblag, without } \\
\text { inventory no.) } \\
\text { phase C1b to the } \\
\text { beginning C2 }\end{array}$ & 15590 & 94,61 & 3,08 & 0,61 & 0,23 & 0,11 & 0 & 0,51 & 0 & 0,86 & 0 & 0 & 0 & 0 & 0 & $\begin{array}{l}\text { Jonakowski 2001, } \\
187 \text {, fig. 2:7 }\end{array}$ \\
\hline 79 & \begin{tabular}{|l|} 
Silver and brass (tongue \\
on the catchplate) brooch \\
with high catchplate, so \\
called Rosettenfibeln, \\
decorated silver gilded \\
foil. Lubieszewo, Nowy \\
Dwór Gdański district. \\
Type close to A. VII, \\
series 4. Group 6 after \\
Lund Hansen, Przybyła. \\
From the catchplate of \\
the brooch. The results of \\
analysis other parts, see \\
Table 1:26-28; 3:16; 4:3.
\end{tabular} & $\begin{array}{c}10 \\
\text { (collections of } \\
\text { the Museum of } \\
\text { Archaeology and } \\
\text { History in } \\
\text { Elblag, without } \\
\text { inventory no.) } \\
\text { phase C1b to the } \\
\text { beginning C2 }\end{array}$ & 15590,01 & 97,16 & 0,43 & 0,37 & 0,1 & 0,23 & 0,07 & 0,2 & 0 & 0,37 & 0,16 & 0 & 0,07 & 0 & 0,82 & \begin{tabular}{|l|} 
Jonakowski 2001 , \\
187 , fig. $2: 7$
\end{tabular} \\
\hline
\end{tabular}




\begin{tabular}{|c|c|c|c|c|c|c|c|c|c|c|c|c|c|c|c|c|c|c|}
\hline 80 & \begin{tabular}{|l|} 
Silver and brass (tongue \\
on the catchplate) brooch \\
with high catchplate, so \\
called Rosettenfibeln, \\
decorated silver gilded \\
foil. Lubieszewo, Nowy \\
Dwór Gdański district. \\
Type close to A. VII, \\
series 4. Group 6 after \\
Lund Hansen, Przybyła. \\
From the catchplate of \\
the brooch. The results of \\
analysis other parts, see \\
Table 1:29.
\end{tabular} & $\begin{array}{c}10 \\
\text { (collections of } \\
\text { the Museum of } \\
\text { Archaeology and } \\
\text { History in } \\
\text { Elblag, without } \\
\text { inventory no.) } \\
\text { phase C1b to the } \\
\text { beginning C2 }\end{array}$ & 15591 & 96,09 & 1,05 & 0,44 & 0,16 & 0,39 & 0,02 & 0,22 & 0,01 & 0,64 & 0 & 0 & 0,3 & 0,69 & 0 & $\begin{array}{l}\text { Jonakowski 2001, } \\
187 \text {, fig. } 2: 8\end{array}$ \\
\hline 81 & \begin{tabular}{|l|} 
Silver crossbow brooch \\
with high catchplate, so \\
called Rosettenfibeln, \\
decorated gold foil. Type \\
close to A. VII, series 4. \\
Group 6 after Lund \\
Hansen, Przybyła. The \\
upper part of the bow. \\
The magnesium content \\
was detected $\mathrm{Mg}=0,52$. \\
The results of analysis \\
other parts, see Table \\
$1: 30$. \\
\end{tabular} & $\begin{array}{c}\text { stray find } \\
(2466) \\
\text { phase } C 1 b \text { to the } \\
\text { beginning } C 2\end{array}$ & 16139 & 84,91 & 6,71 & 0,17 & 0,07 & 0,27 & 0 & 0,41 & 0 & 1,56 & 0 & 3,67 & 0 & 1,73 & 0 & $\begin{array}{l}\text { Natuniewicz- } \\
\text { Sekuła 2010, 414, } \\
\text { fig. 9:11 }\end{array}$ \\
\hline 82 & \begin{tabular}{|l|} 
The fragment of \\
catchplate silver \\
crossbow brooch with \\
high catchplate, so called \\
Rosettenfibeln. Type \\
close to A. VII, series 4. \\
Group 6 after Lund \\
Hansen, Przybyła. From \\
the catchplate. The \\
magnesium content was \\
detected $\mathrm{Mg}=0,62$. \\
\end{tabular} & $\begin{array}{c}\text { stray find } \\
(2462) \\
\text { phase } \mathrm{C} 1 \mathrm{~b} \text { to the } \\
\text { beginning } \mathrm{C} 2\end{array}$ & 16140 & 82,19 & 13,51 & 0,06 & 0,15 & 0,03 & 0 & 0,24 & 0,24 & 0 & 0 & 1,62 & 0 & 1,28 & 0,05 & $\begin{array}{l}\text { Natuniewicz- } \\
\text { Sekuła 2010, 414, } \\
\text { fig. 9:12 }\end{array}$ \\
\hline 83 & $\begin{array}{l}\text { Silver crossbow tendril } \\
\text { brooch with single rings } \\
\text { of beaded wire. Type } \\
\text { close to A.VI.162. The } \\
\text { top side of the foot. The } \\
\text { magnesium content was } \\
\text { detected } \mathrm{Mg}=0,78 \text {. }\end{array}$ & $\begin{array}{c}478 \\
(2403) \\
\text { stadium IVB/V }\end{array}$ & 16145 & 91,08 & 3,89 & 0,33 & 0,04 & 0 & 0,07 & 0,52 & 0 & 0 & 0 & 1,83 & 0 & 1,47 & 0 & $\begin{array}{l}\text { Natuniewicz- } \\
\text { Sekuła, Okulicz- } \\
\text { Kozaryn 2011, } \\
118, \text { pl. CCXI:3 }\end{array}$ \\
\hline
\end{tabular}




\begin{tabular}{|c|c|c|c|c|c|c|c|c|c|c|c|c|c|c|c|c|c|c|}
\hline 84 & $\begin{array}{l}\text { Silver crossbow tendril } \\
\text { brooch, decorated gold } \\
\text { foil. Type A.VI.162. } \\
\text { From upper part of the } \\
\text { bow. The magnesium } \\
\text { content was detected } \\
\text { Mg }=0,7 \text {. The results of } \\
\text { analysis other parts, see } \\
\text { Table 1:31. } \\
\end{array}$ & \begin{tabular}{|c|} 
stray find \\
$(2445)$ \\
phase $\mathrm{C} 1 \mathrm{~b}$ to the \\
beginning $\mathrm{C} 2$
\end{tabular} & 16146 & 94,36 & 1,58 & 0,1 & 0,13 & 0,05 & 0 & 0,25 & 0,17 & 0 & 0 & 1,67 & 0,79 & 0,04 & 0,16 & $\begin{array}{l}\text { Natuniewicz- } \\
\text { Sekuła 2010, 414, } \\
\text { fig. 9:9. Fig. 2:4 }\end{array}$ \\
\hline 85 & $\begin{array}{l}\text { Silver crossbow tendril } \\
\text { brooch. Type A.VI.162. } \\
\text { From the foot. The } \\
\text { magnesium content was } \\
\text { detected } \mathrm{Mg}=0,6 \text {. }\end{array}$ & \begin{tabular}{|c|} 
stray find \\
$(2467)$ \\
phase C1b to the \\
beginning C2
\end{tabular} & 16147 & 93,12 & 2,93 & 0 & 0,08 & 0,17 & 0 & 0,53 & 0,14 & 0,13 & 0,05 & 1,72 & 0,39 & 0,13 & 0 & unpublished \\
\hline 86 & $\begin{array}{l}\text { Silver S-shape clasp. } \\
\text { Type von Müller C. The } \\
\text { wire from a base. The } \\
\text { magnesium content was } \\
\text { detected } \mathrm{Mg}=0,88 \text {. }\end{array}$ & \begin{tabular}{|c|}
485 \\
$(2474)$ \\
stadium IIB/IIC
\end{tabular} & 16149 & 93,33 & 2,64 & 0,27 & 0,04 & 0,02 & 0 & 0,34 & 0 & 0,03 & 0 & 1,51 & 0,26 & 0,69 & 0 & $\begin{array}{l}\text { Natuniewicz- } \\
\text { Sekuła, Okulicz- } \\
\text { Kozaryn 2011, } \\
\text { 119, pl. } \\
\text { CCXVI:485/4 }\end{array}$ \\
\hline 87 & $\begin{array}{l}\text { Fragment of silver } \\
\text { Schlangenkopf bracelet. } \\
\text { Type Wójcik V. From } \\
\text { the bow fragment. The } \\
\text { magnesium content was } \\
\text { detected } \mathrm{Mg}=0,69 \text {. }\end{array}$ & \begin{tabular}{|c|} 
stray find \\
$(2521)$ \\
phase $\mathrm{B} 2 / \mathrm{C} 1$ to \\
C1a
\end{tabular} & 16152 & 90,8 & 3,32 & 0 & 0,05 & 0 & 0 & 0,28 & 0,19 & 0,23 & 0 & 2,99 & 0,47 & 0,98 & 0 & $\begin{array}{l}\text { Natuniewicz- } \\
\text { Sekuła 2010, 414, } \\
\text { fig. 10:16. Fig. 4:3 }\end{array}$ \\
\hline 88 & $\begin{array}{l}\text { Fragment of silver } \\
\text { Schlangenkopf bracelet. } \\
\text { Type Wójcik V. From } \\
\text { the bow fragment. The } \\
\text { magnesium content was } \\
\text { detected } \mathrm{Mg}=0,78 \text {. }\end{array}$ & \begin{tabular}{|c|} 
stray find \\
$(2521 \mathrm{~A})$ \\
phase $\mathrm{B} 2 / \mathrm{C} 1$ to \\
$\mathrm{C} 1 \mathrm{a}$
\end{tabular} & 16153 & 89,85 & 5,41 & 0,06 & 0,02 & 0,04 & 0 & 0,23 & 0,23 & 0 & 0 & 2,43 & 0,4 & 0,56 & 0 & $\begin{array}{l}\text { Natuniewicz- } \\
\text { Sekuła 2010, 414, } \\
\text { fig. 10:17 }\end{array}$ \\
\hline 89 & $\begin{array}{l}\text { Fragment of silver } \\
\text { Schlangenkopf bracelet. } \\
\text { Type Wójcik V. From } \\
\text { the bow fragment. The } \\
\text { magnesium content was } \\
\text { detected } \mathrm{Mg}=0,76 \text {. }\end{array}$ & $\begin{array}{c}\text { stray find } \\
(2521 \mathrm{~B}) \\
\text { phase B2/C1 to } \\
\text { C1a }\end{array}$ & 16154 & 92,75 & 3,02 & 0,08 & 0,13 & 0 & 0,22 & 0,37 & 0,07 & 0,13 & 0 & 2,27 & 0,14 & 0 & 0,08 & $\begin{array}{l}\text { Natuniewicz- } \\
\text { Sekuła 2010, 414, } \\
\text { fig. 10:17 }\end{array}$ \\
\hline
\end{tabular}




\begin{tabular}{|c|c|c|c|c|c|c|c|c|c|c|c|c|c|c|c|c|c|c|}
\hline 90 & \begin{tabular}{|l|} 
Brass spring-covered \\
brooch, decorated with \\
beaded wire on the bow \\
crest. Type A.II.38/40- \\
41. Beaded wire from the \\
bow crest. The \\
magnesium content was \\
detected $\mathrm{Mg}=0,78$. The \\
results of analysis other \\
parts, see Table $3: 25$. \\
\end{tabular} & $\begin{array}{c}502 \\
(2586) \\
\text { stadium IIB/IIC }\end{array}$ & 16156 & 94,46 & 1,52 & 0 & 0,03 & 0 & 0,06 & 0,4 & 0 & 0,18 & 0 & 1,32 & 0 & 1,15 & 0,1 & unpublished \\
\hline 91 & \begin{tabular}{|l|} 
Fragment of silver S- \\
shape clasp. Type von \\
Müller B. Beaded wire \\
surviving by a finial arm \\
of base. The magnesium \\
content was detected \\
Mg=0,67.
\end{tabular} & $\begin{array}{c}505 \\
(2628) \\
\text { stadium } \\
\text { IIIA/IIIB }\end{array}$ & 16160 & 92,45 & 3,19 & 0,03 & 0,01 & 0 & 0 & 0,2 & 0,08 & 0,55 & 0 & 2,24 & 0,45 & 0,13 & 0 & unpublished \\
\hline 92 & $\begin{array}{l}\text { Silver S-shape clasp. } \\
\text { Type von Müller B. The } \\
\text { central granule on the } \\
\text { shield form base } \\
\text { narrowness. The } \\
\text { magnesium content was } \\
\text { detected } \mathrm{Mg}=0,8 \text {. } \\
\end{array}$ & $\begin{array}{c}524 \\
(2676) \\
\text { stadium } \\
\text { IIIA/IIIB }\end{array}$ & 16163 & 94,11 & 1,52 & 0 & 0,27 & 0,13 & 0 & 0,94 & 0,14 & 0 & 0 & 1,53 & 0,31 & 0 & 0,25 & $\begin{array}{l}\text { Natuniewicz- } \\
\text { Sekuła, Skóra } \\
\text { 2016, 63, fig. 2:2 } \\
\text { Fig. 3:1 }\end{array}$ \\
\hline 93 & $\begin{array}{l}\text { Bow of silver crossbow } \\
\text { tendril brooch. Type } \\
\text { close to A.VI.165. From } \\
\text { the foot. The magnesium } \\
\text { content was detected } \\
\mathrm{Mg}=0,68 .\end{array}$ & $\begin{array}{c}\text { stray find } \\
(2707) \\
\text { phase C1b to the } \\
\text { beginning C2 }\end{array}$ & 16165 & 89,55 & 5,23 & 0,17 & 0,34 & 0,21 & 0,09 & 1,28 & 0 & 0 & 0,23 & 0,62 & 0,13 & 1,49 & 0 & $\begin{array}{l}\text { Natuniewicz- } \\
\text { Sekuła 2010, 414, } \\
\text { fig. 9:7 }\end{array}$ \\
\hline 94 & $\begin{array}{l}\text { Fragment of silver ring. } \\
\text { From the ring wire. The } \\
\text { magnesium content was } \\
\text { detected } \mathrm{Mg}=0,72 .\end{array}$ & $\begin{array}{c}\text { stray find } \\
(2709) \\
\text { phase C1b to the } \\
\text { beginning C2 }\end{array}$ & 16166 & 89,52 & 5,68 & 0,21 & 0,3 & 0 & 0 & 0,17 & 0,05 & 0,75 & 0 & 1,22 & 0,71 & 0,67 & 0 & $\begin{array}{l}\text { Natuniewicz- } \\
\text { Sekuła 2010, 415, } \\
\text { fig. 12:50 }\end{array}$ \\
\hline 95 & $\begin{array}{l}\text { Silver strap end fitting. } \\
\text { Type R JII5. From the } \\
\text { lower part. The } \\
\text { magnesium content was } \\
\text { detected } \mathrm{Mg}=0,51 \text {. }\end{array}$ & $\begin{array}{c}\text { stray find } \\
(2710) \\
\text { phase C1b to the } \\
\text { beginning } \mathrm{C} 2\end{array}$ & 16167 & 93,99 & 1,4 & 0 & 0,09 & 0,04 & 0 & 0,1 & 0,05 & 0 & 0,04 & 2,28 & 0,75 & 0,46 & 0,28 & $\begin{array}{l}\text { Natuniewicz- } \\
\text { Sekuła 2010, 415, } \\
\text { fig. 11:47 }\end{array}$ \\
\hline
\end{tabular}




\begin{tabular}{|c|c|c|c|c|c|c|c|c|c|c|c|c|c|c|c|c|c|c|}
\hline 96 & \begin{tabular}{|l|} 
Fragment of silver \\
crossbow brooch with \\
closed catchplate, \\
decorated gold foil. \\
Type A.VI.170. From the \\
foot. The magnesium \\
content was detected \\
Mg=0,74. The results of \\
analysis other parts, see \\
Table 1:32. \\
\end{tabular} & $\begin{array}{c}\text { stray find } \\
(2718) \\
\text { phase C1b to the } \\
\text { beginning } \mathrm{C} 2\end{array}$ & 16168 & 84,11 & 5,32 & 0,21 & 0,25 & 0,08 & 0,12 & 1,21 & 0,16 & 0 & 0 & 3,79 & 0,41 & 3,61 & 0 & $\begin{array}{l}\text { Natuniewicz- } \\
\text { Sekuła 2010, 414, } \\
\text { fig. 9:10 }\end{array}$ \\
\hline 97 & $\begin{array}{l}\text { Fragment of silver ring. } \\
\text { Type Beckmann } 15 . \\
\text { From ring fragment. The } \\
\text { magnesium content was } \\
\text { detected } \mathrm{Mg}=0,76 .\end{array}$ & $\begin{array}{c}\text { stray find } \\
(2735) \\
\text { phase C1b to the } \\
\text { beginning C2 }\end{array}$ & 16169 & 94,71 & 1,89 & 0,23 & 0,36 & 0 & 0 & 0,15 & 0 & 0,14 & 0 & 0,94 & 0,32 & 0,27 & 0,25 & $\begin{array}{l}\text { Natuniewicz- } \\
\text { Sekuła 2010, 415, } \\
\text { fig. 12:51 }\end{array}$ \\
\hline 98 & $\begin{array}{l}\text { Frame of silver belt } \\
\text { buckle. Type ML D29. } \\
\text { from top side of a frame. }\end{array}$ & $\begin{array}{c}\text { stray find } \\
(2736) \\
\text { phase } \mathrm{C} 1 \mathrm{~b} \text { to the } \\
\text { beginning } \mathrm{C} 2\end{array}$ & 16170 & 92,8 & 1,22 & 0,25 & 0,41 & 0 & 0,06 & 0,44 & 0 & 0,14 & 0 & 1,74 & 0,26 & 1,44 & 1,25 & $\begin{array}{l}\text { Natuniewicz- } \\
\text { Sekuła 2010, 415, } \\
\text { fig. 11:46 }\end{array}$ \\
\hline 99 & $\begin{array}{l}\text { Silver pin. Type } \\
\text { Beckmann group X. } \\
\text { From pin shaft. The } \\
\text { magnesium content was } \\
\text { detected } \mathrm{Mg}=0,74 .\end{array}$ & $\begin{array}{c}\text { stray find } \\
(2737) \\
\text { phase C1b to the } \\
\text { beginning } \mathrm{C} 2\end{array}$ & 16171 & 87,26 & 6,28 & 0,27 & 0,19 & 0 & 0 & 0,46 & 0 & 0 & 0 & 3,35 & 0,49 & 0,42 & 0,55 & $\begin{array}{l}\text { Natuniewicz- } \\
\text { Sekuła 2010, } 415 \text {, } \\
\text { fig. } 12: 53\end{array}$ \\
\hline 100 & $\begin{array}{l}\text { Fragment of silver } \\
\text { wellenförmige bracelet. } \\
\text { Wire from the crossbar } \\
\text { for fastening a capsule. } \\
\text { The magnesium content } \\
\text { was detected } \mathrm{Mg}=0,79 \text {. }\end{array}$ & \begin{tabular}{|c|} 
stray find \\
$(2921)$ \\
phase $\mathrm{B} 2 / \mathrm{C} 1$ to \\
$\mathrm{C} 1 \mathrm{a}$
\end{tabular} & 16172 & 88,83 & 5,36 & 0,25 & 0,5 & 0 & 0 & 1,06 & 0,06 & 0 & 0 & 1,9 & 0,21 & 1,04 & 0 & $\begin{array}{l}\text { Natuniewicz- } \\
\text { Sekuła 2010, 414, } \\
\text { fig. 11:32 }\end{array}$ \\
\hline 101 & $\begin{array}{l}\text { Silver brooch with high } \\
\text { catchplate and upper } \\
\text { chord. Type A.VII, } \\
\text { series } 1 \text {. From upper part } \\
\text { of a bow. The } \\
\text { magnesium content was } \\
\text { detected } \mathrm{Mg}=0,76 \text {. }\end{array}$ & $\begin{array}{c}28 \\
(106) \\
\text { stadium IIIB }\end{array}$ & 16192 & 90,12 & 7,05 & 0,06 & 0,04 & 0 & 0 & 0 & 0,15 & 0,16 & 0 & 1,21 & 0 & 0,43 & 0 & $\begin{array}{l}\text { Natuniewicz- } \\
\text { Sekuła, Okulicz- } \\
\text { Kozaryn 2011, 31, } \\
\text { pl. XII:28/1 }\end{array}$ \\
\hline
\end{tabular}




\begin{tabular}{|c|c|c|c|c|c|c|c|c|c|c|c|c|c|c|c|c|c|c|}
\hline 102 & \begin{tabular}{|l|} 
Brass brooch decorated \\
silver foil. Type A.V, \\
series 11 or type Leonów \\
after Jamka. From the \\
foil on the upper part of \\
the bow. The \\
magnesium content was \\
detected $\mathrm{Mg}=0,78$. The \\
results of analysis other \\
parts, see Table $3: 60$.
\end{tabular} & $\begin{array}{c}267 \\
(1161) \\
\text { stadium IIB/IIC }\end{array}$ & 16205 & 93,94 & 0,87 & 0,11 & 0,14 & 0,07 & 0,01 & 0,42 & 0,01 & 0,16 & 0 & 1,95 & 0,15 & 1,4 & 0 & $\begin{array}{l}\text { Natuniewicz- } \\
\text { Sekuła, Okulicz- } \\
\text { Kozaryn 2011, 78, } \\
\text { pl. CXIII:1 }\end{array}$ \\
\hline 103 & $\begin{array}{l}\text { Brass brooch decorated } \\
\text { silver foil. Type A.V, } \\
\text { series } 11 \text { or type Leonów } \\
\text { after Jamka. From the } \\
\text { foil on the lower part of } \\
\text { the bow. The } \\
\text { magnesium content was } \\
\text { detected } \mathrm{Mg}=0,67 . \text { The } \\
\text { results of analysis other } \\
\text { parts, see Table } 3: 61 .\end{array}$ & $\begin{array}{c}267 \\
(1165) \\
\text { stadium IIB/IIC }\end{array}$ & 16206 & 92,33 & 2,87 & 0,24 & 0,08 & 0,1 & 0 & 0 & 0 & 0 & 0,39 & 1,91 & 0,32 & 1,1 & 0 & $\begin{array}{l}\text { Natuniewicz- } \\
\text { Sekuła, Okulicz- } \\
\text { Kozaryn 2011, 78, } \\
\text { pl. CXIII:2 }\end{array}$ \\
\hline 104 & \begin{tabular}{|l|} 
Brass bow of the \\
crossbow brooch \\
(melted), preserved with \\
melted on it a lump of \\
silver. Elblag, Pole \\
Nowomiejskie, Elblag \\
district. Type A.VI.167. \\
From lump of silver. \\
The magnesium content \\
was detected Mg=0,62. \\
The results of analysis \\
other parts, see Table \\
3:64. \\
\end{tabular} & $\begin{array}{c}\text { no grave number } \\
\text { (collections of } \\
\text { the Museum of } \\
\text { Archaeology and } \\
\text { History in } \\
\text { Elblag, inventory } \\
\text { no. 181/478) } \\
\text { phase C2a }\end{array}$ & 16209 & 72,35 & 19,08 & 0,02 & 0,06 & 0,25 & 0 & 0,34 & 0 & 0,55 & 0,27 & 5,43 & 0,17 & 0,86 & 0 & $\begin{array}{l}\text { Natuniewicz } \\
2000,143 \text {, pl. II:7 }\end{array}$ \\
\hline 105 & \begin{tabular}{|l|} 
Fragment of silver \\
Schlangenkopf bracelet. \\
Weklice or Myślęcin, \\
Elblag district. Type \\
Wójcik V. From the bow \\
fragment. The \\
magnesium content was \\
detected $\mathrm{Mg}=0,81$.
\end{tabular} & \begin{tabular}{|c|} 
no grave number \\
(collections of \\
the Museum of \\
Archaeology and \\
History in \\
Elblag, inventory \\
no. $124 / 336$ ) \\
phase B2/C1 to \\
C1a
\end{tabular} & 16217 & 93,93 & 2,87 & 0 & 0,02 & 0,1 & 0 & 0,05 & 0 & 0,29 & 0 & 1,61 & 0,2 & 0,13 & 0 & $\begin{array}{l}\text { Natuniewicz- } \\
\text { Sekuła, Okulicz- } \\
\text { Kozaryn 2011, } \\
\text { 121, pl. CCXX:2. } \\
\text { Fig. 4:2 }\end{array}$ \\
\hline
\end{tabular}




\begin{tabular}{|c|c|c|c|c|c|c|c|c|c|c|c|c|c|c|c|c|c|c|}
\hline 106 & $\begin{array}{l}\text { Fragment of silver } \\
\text { Schlangenkopf bracelet. } \\
\text { Weklice or Myślęcin, } \\
\text { Elblag district. Type } \\
\text { Wójcik V. From the } \\
\text { gorget on the head. The } \\
\text { magnesium content was } \\
\text { detected } \mathrm{Mg}=0,79 \text {. }\end{array}$ & \begin{tabular}{|c|} 
no grave number \\
(collections of \\
the Museum of \\
Archaeology and \\
History in \\
Elblag, inventory \\
no. $124 / 336$ ) \\
phase B2/C1 to \\
C1a \\
\end{tabular} & 16217,01 & 93,91 & 1,58 & 0 & 0,35 & 0,16 & 0,07 & 0,29 & 0,21 & 0,51 & 0 & 1,68 & 0,13 & 0,32 & 0 & $\begin{array}{l}\text { Natuniewicz- } \\
\text { Sekuła, Okulicz- } \\
\text { Kozaryn 2011, } \\
\text { 121, pl. CCXX:2. } \\
\text { Fig. 4:2 }\end{array}$ \\
\hline 107 & $\begin{array}{l}\text { Silver S-shape claps. } \\
\text { Type von Müller B. } \\
\text { Beaded wire from a base. } \\
\text { The magnesium content } \\
\text { was detected } \mathrm{Mg}=63 \text {. }\end{array}$ & $\begin{array}{c}542 \\
(2939) \\
\text { stadium IIIB }\end{array}$ & 16223 & 92,76 & 2,73 & 0,04 & 0,32 & 0,03 & 0 & 0,27 & 0,22 & 0 & 0,14 & 2,04 & 0,61 & 0,16 & 0,05 & unpublished \\
\hline 108 & $\begin{array}{l}\text { Fragment silver } \\
\text { fastening capsule of } \\
\text { wellenförmige bracelet. } \\
\text { The central part of the } \\
\text { capsule top shield. The } \\
\text { magnesium content was } \\
\text { detected } \mathrm{Mg}=0,75 \text {. } \\
\end{array}$ & \begin{tabular}{|c|} 
stray find \\
$(2899)$ \\
phase $\mathrm{B} 2 / \mathrm{C} 1$ to \\
C1a
\end{tabular} & 16227 & 89,34 & 3,7 & 1,17 & 0 & 0,11 & 0 & 0,24 & 0 & 0,1 & 0 & 3,97 & 0,1 & 0,52 & 0 & $\begin{array}{l}\text { Natuniewicz- } \\
\text { Sekuła 2010, 414, } \\
\text { fig. 11:28a }\end{array}$ \\
\hline 109 & $\begin{array}{l}\text { Fragment of hoop silver } \\
\text { wellenförmige bracelet. } \\
\text { The wire from a hoop. } \\
\text { The magnesium content } \\
\text { was detected } \mathrm{Mg}=0,71 .\end{array}$ & $\begin{array}{c}\text { stray find } \\
(2544) \\
\text { phase B2/C1to } \\
\text { C1a }\end{array}$ & 16228 & 82,4 & 10,21 & 0,63 & 0 & 0,04 & 0 & 0,91 & 0,12 & 0,1 & 0 & 3,57 & 0,15 & 1,17 & 0 & $\begin{array}{l}\text { Natuniewicz- } \\
\text { Sekuła 2010, 414, } \\
\text { fig. 11:34 }\end{array}$ \\
\hline 110 & $\begin{array}{l}\text { Fragment of head silver } \\
\text { Schlangenkopf bracelet. } \\
\text { Type Wójcik V. From } \\
\text { central part of the head. } \\
\text { The magnesium content } \\
\text { was detected } \mathrm{Mg}=0,73 .\end{array}$ & \begin{tabular}{|c|} 
stray find \\
$(2804)$ \\
phase B2/C1 to \\
C1a
\end{tabular} & 16229 & 92,45 & 2,43 & 0,61 & 0,01 & 0 & 0,09 & 0,9 & 0 & 0,4 & 0 & 1,47 & 0,08 & 0,74 & 0,1 & $\begin{array}{l}\text { Natuniewicz- } \\
\text { Sekuła 2010, 414, } \\
\text { fig. 10:23 }\end{array}$ \\
\hline 111 & $\begin{array}{l}\text { Silver S-shape claps. } \\
\text { Type von Müller C. The } \\
\text { wire from a base. The } \\
\text { magnesium content was } \\
\text { detected } \mathrm{Mg}=0,85 \text {. }\end{array}$ & $\begin{array}{c}\text { stray find } \\
(2784) \\
\text { phase B2b-B2c }\end{array}$ & 16230 & 94,96 & 0,96 & 0,06 & 0,16 & 0,17 & 0,04 & 0,22 & 0 & 0 & 0 & 2 & 0,27 & 0,23 & 0,09 & unpublished \\
\hline
\end{tabular}




\begin{tabular}{|c|c|c|c|c|c|c|c|c|c|c|c|c|c|c|c|c|c|c|}
\hline 112 & $\begin{array}{l}\text { Fragment silver } \\
\text { fastening capsule of } \\
\text { wellenförmige bracelet. } \\
\text { The lateral part of } \\
\text { capsule. The magnesium } \\
\text { content was detected } \\
\mathrm{Mg}=0,83 \text {. }\end{array}$ & $\begin{array}{c}\text { stray find } \\
(2920) \\
\text { phase B2/C1 to } \\
\text { C1a }\end{array}$ & 16231 & 92,92 & 2,09 & 0,15 & 0,13 & 0,07 & 0,32 & 0,61 & 0 & 0,49 & 0 & 1,61 & 0,43 & 0,32 & 0,03 & $\begin{array}{l}\text { Natuniewicz- } \\
\text { Sekuła } 2010,414 \text {, } \\
\text { fig. } 11: 28 \text { b }\end{array}$ \\
\hline 113 & $\begin{array}{l}\text { Fragment silver } \\
\text { fastening capsule of } \\
\text { wellenförmige bracelet. } \\
\text { The lateral part of } \\
\text { capsule. The magnesium } \\
\text { content was detected } \\
\mathrm{Mg}=0,71 . \\
\end{array}$ & $\begin{array}{c}\text { stray find } \\
(2919) \\
\text { phase } \mathrm{B} 2 / \mathrm{C} 1 \text { to } \\
\text { C1a }\end{array}$ & 16232 & 93,08 & 1,74 & 0,72 & 0,24 & 0 & 0 & 0,36 & 0,34 & 0,19 & 0 & 1,84 & 0,34 & 0,43 & 0 & $\begin{array}{l}\text { Natuniewicz- } \\
\text { Sekuła } 2010,414 \text {, } \\
\text { fig. } 11: 29\end{array}$ \\
\hline 114 & $\begin{array}{l}\text { Silver S-shape claps. } \\
\text { Type von Müller B. The } \\
\text { beaded wire from a base. } \\
\text { The magnesium content } \\
\text { was detected } \mathrm{Mg}=0,73 \text {. }\end{array}$ & $\begin{array}{c}342 \\
(1702) \\
\text { stadium IIIB }\end{array}$ & 16233 & 94,45 & 3,27 & 0,25 & 0 & 0 & 0,14 & 0,23 & 0,15 & 0 & 0 & 0,26 & 0,47 & 0 & 0,07 & $\begin{array}{l}\text { Natuniewicz- } \\
\text { Sekuła, Okulicz- } \\
\text { Kozaryn 2011, 93, } \\
\text { pl. CL:9 }\end{array}$ \\
\hline
\end{tabular}


Table 3. Results of the chemical composition analyzes, Group 3 - copper and its alloys, tin coatings (prepared by M. Natuniewicz-Sekuła)

\begin{tabular}{|c|c|c|c|c|c|c|c|c|c|c|c|c|c|c|c|c|c|c|c|c|c|c|}
\hline No. & $\begin{array}{l}\text { Description of the find/the } \\
\text { analyzed part of } \\
\text { find/Additional comments }\end{array}$ & $\begin{array}{c}\text { Grave no./ } \\
\text { inventory } \\
\text { no. } / \\
\text { chronology }\end{array}$ & $\begin{array}{c}\text { Sample } \\
\text { no. }\end{array}$ & $\mathrm{Cu}$ & Mg & Al & $\mathrm{Si}$ & Ti & $\mathrm{Cr}$ & Mn & $\mathrm{Fe}$ & $\mathrm{Ni}$ & Zn & As & Ag & Sn & Sb & $\mathbf{P b}$ & $\mathbf{P}$ & $\mathrm{s}$ & Au & $\begin{array}{l}\text { Literature / } \\
\text { figure no. }\end{array}$ \\
\hline 1 & $\begin{array}{l}\text { Bipartite buckle. Frame of tin- } \\
\text { lead bronze, buckle plate of } \\
\text { brass. } \\
\text { Type close to ML E29. } \\
\text { The buckle frame. }\end{array}$ & $\begin{array}{c}208 \\
(807) \\
\text { stadium } \\
\text { IIIA/IIIB } \\
\end{array}$ & 15531 & 62,06 & 0 & 0,26 & 0,69 & 0 & 0 & 0 & 0,32 & 0 & 0 & 0 & 0 & 33,27 & 0 & 2,62 & 0 & 0 & 0,79 & $\begin{array}{l}\text { Natuniewicz-Sekuła, } \\
\text { Okulicz-Kozaryn 2011, } \\
\text { 66, pl. LXXXIII:9. } \\
\text { Fig. 7:1 } \\
\end{array}$ \\
\hline 2 & $\begin{array}{l}\text { Bipartite buckle. Frame of tin- } \\
\text { lead bronze, buckle plate of } \\
\text { brass. } \\
\text { Type close to ML E29. } \\
\text { The buckle plate. }\end{array}$ & $\begin{array}{c}208 \\
\text { (807) stadium } \\
\text { IIIA/IIIB }\end{array}$ & 15531,01 & 84,91 & 0 & 0,4 & 1,18 & 0,02 & 0,14 & 0,05 & 0,47 & 0 & 8,63 & 0,03 & 0,38 & 1,27 & 0,61 & 1,63 & 0 & 0,25 & 0,03 & $\begin{array}{l}\text { Natuniewicz-Sekuła, } \\
\text { Okulicz-Kozaryn 2011, } \\
\text { 66, pl. LXXXIII:9. } \\
\text { Fig. 7:1 }\end{array}$ \\
\hline 3 & $\begin{array}{l}\text { Tin-lead bronze strap end fitting. } \\
\text { Type close to R III3. } \\
\text { The upper part of shaft. }\end{array}$ & $\begin{array}{l}208 \\
(808) \text { stadium } \\
\text { IIIA/IIIB }\end{array}$ & 15535 & 79,27 & 0 & 0,1 & 0,51 & 0 & 0 & 0 & 1,15 & 0 & 4,42 & 0 & 0 & 9,44 & 0 & 5,06 & 0 & 0 & 0,05 & $\begin{array}{l}\text { Natuniewicz-Sekuta, } \\
\text { Okulicz-Kozaryn 2011, } \\
66 \text {, pl. LXXXIII:10. } \\
\text { Fig. 7:2 }\end{array}$ \\
\hline 4 & $\begin{array}{l}\text { Tin-lead bronze slant grooved } \\
\text { kettle. } \\
\text { Type Eggers } 48 \text {. } \\
\text { From the fragment of body. }\end{array}$ & $\begin{array}{c}208 \\
\text { (812) stadium } \\
\text { IIIA/IIIB }\end{array}$ & 15536 & 86,36 & 0 & 0,3 & 0,34 & 0 & 0 & 0 & 0,4 & 0 & 0,41 & 0 & 0 & 11,71 & 0 & 0,22 & 0 & 0 & 0,26 & $\begin{array}{l}\text { Natuniewicz-Sekuła, } \\
\text { Okulicz-Kozaryn 2011, } \\
\text { 66, pl. LXXXIV:15 }\end{array}$ \\
\hline 5 & $\begin{array}{l}\text { Brass brooch with traces of tin } \\
\text { coating. } \\
\text { Type A.V, series } 11 \text {, typ } \\
\text { Leonów after Jamka. } \\
\text { The bottom side of the bow. }\end{array}$ & $\begin{array}{l}386 \\
(1942) \\
\text { stadium } \\
\text { IIB/IIC }\end{array}$ & 15544 & 91,24 & 0 & 0,23 & 0,25 & 0,03 & 0 & 0 & 0,18 & 0,03 & 4,89 & 0 & 0,11 & 1,91 & 0,06 & 0,79 & 0 & 0,24 & 0,02 & $\begin{array}{l}\text { Natuniewicz-Sekuła, } \\
\text { Okulicz-Kozaryn 2011, } \\
\text { 101, pl. CLXVIII:386/2. } \\
\text { Fig. 8:2 }\end{array}$ \\
\hline 6 & $\begin{array}{l}\text { Brass brooch with traces of tin } \\
\text { coating. } \\
\text { Type A.V, series } 11 \text {, typ } \\
\text { Leonów after Jamka. } \\
\text { Tin coating on the bow. }\end{array}$ & $\begin{array}{l}386 \\
(1942) \\
\text { stadium } \\
\text { IIB/IIC } \\
\end{array}$ & 15544,01 & 7,14 & 0 & 0,54 & 0,59 & 0 & 0 & 0 & 0,29 & 0 & 0,52 & 0 & 36,47 & 54,1 & 0 & 0 & 0 & 0,19 & 0,16 & $\begin{array}{l}\text { Natuniewicz-Sekuła, } \\
\text { Okulicz-Kozaryn 2011, } \\
\text { 101, pl. CLXVIII:386/2. } \\
\text { Fig. 8:2 }\end{array}$ \\
\hline 7 & $\begin{array}{l}\text { Brass crest-headed brooch with } \\
\text { cylinder for the spring, } \\
\text { decorated silver foil. } \\
\text { Type with features to A.V. } 126 \\
\text { and A.V.130. } \\
\text { The bottom side of the bow. } \\
\text { The results of analysis other } \\
\text { parts, see Table 2:21. }\end{array}$ & $\begin{array}{l}386 \\
(1943) \\
\text { stadium } \\
\text { IIB/IIC }\end{array}$ & 15545 & 78,38 & 0 & 0,13 & 0,3 & 0 & 0 & 0 & 0,38 & 0,02 & 13,11 & 0 & 0,09 & 4,23 & 0 & 3,13 & 0 & 0 & 0,24 & $\begin{array}{l}\text { Natuniewicz-Sekuła, } \\
\text { Okulicz-Kozaryn 2011, } \\
\text { 101, pl. CLXVIII:386/1. } \\
\text { Fig. 8:1 }\end{array}$ \\
\hline 8 & $\begin{array}{l}\text { Brass crest-headed brooch with } \\
\text { cylinder for the spring, } \\
\text { decorated silver foil. } \\
\text { Type with features to A.V. } 126 \\
\text { and A.V.130. } \\
\text { Tin coating on the bow. } \\
\text { The results of analysis other } \\
\text { parts, see Table 2:21. }\end{array}$ & $\begin{array}{l}386 \\
(1943) \\
\text { stadium } \\
\text { IIB/IIC }\end{array}$ & 15545,01 & 14,15 & 0 & 0,28 & 0,52 & 0 & 0 & 0 & 0,33 & 0 & 1,04 & 0 & 4,39 & 76,84 & 0 & 2,12 & 0,25 & 0 & 0,08 & $\begin{array}{l}\text { Natuniewicz-Sekuta, } \\
\text { Okulicz-Kozaryn 2011, } \\
\text { 101, pl. CLXVIII:386/1. } \\
\text { Fig. 8:1 }\end{array}$ \\
\hline 9 & $\begin{array}{l}\text { Brass triple-crest brooch and } \\
\text { cylinder for the spring, with } \\
\text { traces of silver foil on the } \\
\text { cylinder. } \\
\text { Type A.V.96. } \\
\text { The bottom side of the bow. } \\
\text { The results of analysis other } \\
\text { parts, see Table 2:48. }\end{array}$ & $\begin{array}{l}25 \\
(72) \\
\text { stadium } \\
\text { IIB/IIC }\end{array}$ & 15562 & 85,95 & 0 & 1,24 & 0,41 & 0 & 0,02 & 0 & 0,79 & 0 & 5,24 & 0 & 0 & 4,34 & 0 & 1,85 & 0 & 0,16 & 0 & $\begin{array}{l}\text { Natuniewicz-Sekuła, } \\
\text { Okulicz-Kozaryn 2011, } \\
\text { 30, pl. VII:1 }\end{array}$ \\
\hline
\end{tabular}




\begin{tabular}{|c|c|c|c|c|c|c|c|c|c|c|c|c|c|c|c|c|c|c|c|c|c|c|}
\hline 10 & $\begin{array}{l}\text { Silver crossbow brooch with } \\
\text { high catchplate, so called } \\
\text { Rosettenfibeln, decorated gold } \\
\text { foil, knobs made of brass. } \\
\text { Type close to A. VII, series } 4 \text {. } \\
\text { Group } 6 \text { after Lund Hansen, } \\
\text { Przybyła. } \\
\text { The brass knob with rosette gold } \\
\text { foil from central part of the bow. } \\
\text { The results of analysis other } \\
\text { parts, see Table 1:16-17; } 2: 37 \text { - } \\
\text { 38. }\end{array}$ & $\begin{array}{c}150 \\
(607) \\
\text { stadium } \\
\text { IVA/IVB }\end{array}$ & 15556 & 83,94 & 0 & 1,31 & 1,18 & 0 & 0,08 & 0 & 0,43 & 0 & 10,02 & 0 & 2,13 & 0,24 & 0,07 & 0,48 & 0 & 0 & 0,12 & $\begin{array}{l}\text { Natuniewicz-Sekuła, } \\
\text { Okulicz-Kozaryn 2011, } \\
\text { 55-56, pl. LX:4 }\end{array}$ \\
\hline 11 & $\begin{array}{l}\text { Brass triple-crest brooch, } \\
\text { decorated silver foil. } \\
\text { Type A.V. } 96 \text {. } \\
\text { The bottom side of the bow. } \\
\text { The results of analysis other } \\
\text { parts, see Table } 2: 55 \text {. }\end{array}$ & $\begin{array}{l}26 \mathrm{~B} \\
(123) \\
\text { stadium } \\
\text { IIB/IIC }\end{array}$ & 15568 & 88,44 & 0 & 0,1 & 0,26 & 0,06 & 0 & 0,03 & 0,76 & 0 & 7,33 & 0 & 0 & 2,06 & 0 & 0,7 & 0 & 0,25 & 0,01 & $\begin{array}{l}\text { Natuniewicz-Sekuta, } \\
\text { Okulicz-Kozaryn 2011, } \\
\text { 31, pl. XI:3-3a }\end{array}$ \\
\hline 12 & $\begin{array}{l}\text { Brass brooch with high } \\
\text { catchlplate and cylinder for the } \\
\text { spring, decorated silver gilded } \\
\text { foil. } \\
\text { Type with features A.V. series } 2 \\
\text { and } 8 \text { and A.VII, series 1. } \\
\text { The bottom side of the bow. } \\
\text { The results of analysis other } \\
\text { parts, see Table 1:22. }\end{array}$ & $\begin{array}{c}184 \\
(677) \\
\text { stadium IVB }\end{array}$ & 15569 & 87,21 & 0 & 0,18 & 0,37 & 0 & 0,05 & 0 & 0,43 & 0,09 & 5,58 & 0 & 0,35 & 1,77 & 0,45 & 2,96 & 0 & 0,49 & 0,08 & $\begin{array}{l}\text { Natuniewicz-Sekuła, } \\
\text { Okulicz-Kozaryn 2011, } \\
\text { 62, pl. LXXVIII:2 }\end{array}$ \\
\hline 13 & $\begin{array}{l}\text { Tin-lead disc brooch with } \\
\text { enamel. } \\
\text { Type Riha } 7.14 . \\
\text { The upper part of a disc. }\end{array}$ & $\begin{array}{c}184 \\
(676) \\
\text { stadium IVB }\end{array}$ & 15570 & 73,25 & 0 & 0,09 & 0,2 & 0 & 0 & 0 & 0,37 & 0 & 4,1 & 0 & 0 & 11,95 & 0 & 10,04 & 0 & 0 & 0 & $\begin{array}{l}\text { Natuniewicz-Sekuła, } \\
\text { Okulicz-Kozaryn 2011, } \\
\text { 62, pl. LXXVII:1. } \\
\text { Fig. 6:1 }\end{array}$ \\
\hline 14 & $\begin{array}{l}\text { Brass brooch with cylinder for } \\
\text { the spring and crest on the head } \\
\text { and foot terminal, decorated } \\
\text { silver foil. } \\
\text { Type with features A.V, series } 1 \\
\text { and A.V, series } 8 \text {. } \\
\text { The bottom side of the bow. } \\
\text { The results of analysis other } \\
\text { parts, see Table 2:56. }\end{array}$ & $\begin{array}{c}402 \\
(2009) \\
\text { stadium } \\
\text { IIIA/IIIB }\end{array}$ & 15571 & 88,31 & 0 & 0,19 & 0,33 & 0 & 0,09 & 0 & 0,46 & 0 & 8,18 & 0 & 0,27 & 1 & 0,25 & 0,78 & 0 & 0,15 & 0 & $\begin{array}{l}\text { Natuniewicz-Sekula, } \\
\text { Okulicz-Kozaryn 2011, } \\
\text { 104, pl. CLXXXI:3 }\end{array}$ \\
\hline 15 & $\begin{array}{l}\text { Brass brooch with cylinder for } \\
\text { the spring, crest on the head and } \\
\text { circular disc on the foot, } \\
\text { decorated silver foil, filigree and } \\
\text { granulatition. } \\
\text { Type with features A.V, series } 1 \\
\text { and A.V, series } 8 \text {. } \\
\text { The catchplate of a brooch. } \\
\text { The results of analysis other } \\
\text { parts, see Table 2:65-66. }\end{array}$ & $\begin{array}{c}252 \\
(1059) \\
\text { stadium IIIB }\end{array}$ & 15576 & 91,52 & 0 & 1,14 & 0,32 & 0 & 0 & 0 & 0,52 & 0 & 0,96 & 0 & 0,09 & 4,86 & 0 & 0,27 & 0 & 0,31 & 0 & $\begin{array}{l}\text { Natuniewicz-Sekuła, } \\
\text { Okulicz-Kozaryn 2011, } \\
\text { 75, pl. CI:252/3. } \\
\text { Fig. } 3: 3\end{array}$ \\
\hline 16 & $\begin{array}{l}\text { Silver and brass (tongue on the } \\
\text { catchplate) brooch with high } \\
\text { catchplate, so called } \\
\text { Rosettenfibeln, decorated silver } \\
\text { gilded foil. } \\
\text { Lubieszewo, Nowy Dwór } \\
\text { Gdański district. } \\
\text { Type close to A. VII, series } 4 \text {. } \\
\text { Group } 6 \text { after Lund Hansen, } \\
\text { Przybyła. } \\
\text { From tongue on the catchplate. } \\
\text { The resultto af analysis other } \\
\text { parts, see Table } 1: 26-28 ; 2: 78- \\
79 ; 4: 3 \text {. }\end{array}$ & $\begin{array}{l}10 \\
\text { (collections } \\
\text { of the } \\
\text { Museum of } \\
\text { Archaeology } \\
\text { and History } \\
\text { in Elblag, } \\
\text { without } \\
\text { inventory no.) } \\
\text { phase Clb to } \\
\text { the begining } \\
\text { C2 }\end{array}$ & 15590 & 94,84 & 0 & 0,17 & 0,57 & 0 & 0 & 0 & 0,45 & 0 & 0,76 & 0,92 & 0,21 & 1,83 & 0 & 0,24 & 0 & 0 & 0 & $\begin{array}{l}\text { Jonakowski 2001, 187, } \\
\text { fig. } 2: 7\end{array}$ \\
\hline
\end{tabular}




\begin{tabular}{|c|c|c|c|c|c|c|c|c|c|c|c|c|c|c|c|c|c|c|c|c|c|}
\hline No. & $\begin{array}{l}\text { Description of the find/the } \\
\text { analyzed part of } \\
\text { find/Additional comments }\end{array}$ & $\begin{array}{c}\text { Grave no./ } \\
\text { inventory } \\
\text { no. } / \\
\text { chronology } \\
\end{array}$ & $\begin{array}{c}\text { Sample } \\
\text { no. }\end{array}$ & $\mathrm{Cu}$ & Al & $\mathrm{Si}$ & $\mathrm{Ti}$ & $\mathrm{Cr}$ & Mn & $\mathbf{F e}$ & $\mathrm{Ni}$ & $\mathbf{Z n}$ & As & Ag & Sn & $\mathbf{S b}$ & $\mathbf{P b}$ & $\mathbf{P}$ & $\mathrm{s}$ & $\mathrm{Au}$ & Literature / figure no. \\
\hline 17 & $\begin{array}{l}\text { Brass triple-crest brooch with } \\
\text { cylinder for the spring with } \\
\text { traces of silver foil. } \\
\text { Type A.V.96. } \\
\text { From lower part of the bow. }\end{array}$ & $\begin{array}{l}480 \\
\text { (2448) } \\
\text { stadium } \\
\text { IIB/IIC }\end{array}$ & 16141 & 80,2 & 0,1 & 0 & 0 & 0 & 0 & 0,7 & 0,2 & 13,47 & 0,44 & 0,08 & 1,95 & 0,13 & 2,54 & 0 & 0,01 & 0,17 & $\begin{array}{l}\text { Natuniewicz-Sekuła, } \\
\text { Okulicz-Kozaryn 2011, } \\
\text { 118, pl. CCXIV:1 }\end{array}$ \\
\hline 18 & $\begin{array}{l}\text { Brass eye brooch. } \\
\text { Type close to A.III. } 50-53 . \\
\text { From the bow. }\end{array}$ & $\begin{array}{c}489 \\
(2506) \\
\text { stadium IA }\end{array}$ & 16142 & 78,46 & 0,19 & 0,06 & 0,03 & 0,02 & 0 & 0,3 & 0 & 18,52 & 0 & 0,23 & 1,4 & 0 & 0,8 & 0 & 0 & 0 & $\begin{array}{l}\text { Natuniewicz-Sekula, } \\
\text { Okulicz-Kozaryn 2011, } \\
\text { 120, pl. CCXVIII:489/1 }\end{array}$ \\
\hline 19 & $\begin{array}{l}\text { Brass rod bracelet. } \\
\text { Type Natuniewicz } 2 . \\
\text { From the hoop of bracelet. }\end{array}$ & $\begin{array}{c}492 \\
(2525) \\
\text { stadium IA }\end{array}$ & 16143 & 78,17 & 0,08 & 0 & 0,14 & 0 & 0 & 0,28 & 0,02 & 19,52 & 0,19 & 0,09 & 0,81 & 0,15 & 0,54 & 0 & 0 & 0 & $\begin{array}{l}\text { Natuniewicz-Sekula, } \\
\text { Okulicz-Kozaryn 2011, } \\
\text { 120, pl. CCXIX:4. } \\
\text { Fig. 5:4 }\end{array}$ \\
\hline 20 & $\begin{array}{l}\text { Brass eye brooch. } \\
\text { Type A.III.57. } \\
\text { From the bow. }\end{array}$ & $\begin{array}{c}492 \\
(2527) \\
\text { stadium IA }\end{array}$ & 16144 & 76,85 & 0,15 & 0 & 0 & 0,08 & 0,02 & 0,22 & 0 & 21,28 & 0,3 & 0 & 0,55 & 0 & 0,53 & 0 & 0,02 & 0 & $\begin{array}{l}\text { Natuniewicz-Sekula, } \\
\text { Okulicz-Kozaryn 2011, } \\
\text { 120, pl. CCXIX:1 }\end{array}$ \\
\hline 21 & $\begin{array}{l}\text { Tin-lead bronze strap end fitting } \\
\text { with traces of silver rivet. Type } \\
\text { R O15. } \\
\text { From the top side of the } \\
\text { attachment end. } \\
\text { The results of analysis other } \\
\text { parts, see Table 4:4-5. }\end{array}$ & $\begin{array}{l}\text { stray find } \\
(2469) \\
\text { phase C1b to } \\
\text { the beginning } \\
\text { C2 }\end{array}$ & 16148 & 77,89 & 0,11 & 0 & 0 & 0 & 0 & 0,3 & 0,07 & 0,25 & 0 & 0,12 & 8,59 & 0 & 12,37 & 0 & 0 & 0,3 & $\begin{array}{l}\text { Natuniewicz-Sekuła } \\
2010,415 \text {, fig. 11:48 }\end{array}$ \\
\hline 22 & $\begin{array}{l}\text { Brass crossbow brooch with } \\
\text { high catchplate. } \\
\text { Type A VII, series } 1 . \\
\text { From the catchplate. } \\
\text { The results of analysis other } \\
\text { parts, see Table } 4: 6 \text {. }\end{array}$ & $\begin{array}{c}24 \\
(2485) \\
\text { stadium IIIB }\end{array}$ & 16150 & 92,68 & 0,02 & 0,08 & 0 & 0 & 0,11 & 0,18 & 0 & 2,17 & 0,17 & 0,05 & 1,48 & 0,01 & 2,94 & 0 & 0,1 & 0 & $\begin{array}{l}\text { Natuniewicz-Sekuła, } \\
\text { Okulicz-Kozaryn 2011, } \\
\text { 30, pl.VIII:24/1. } \\
\text { Fig. 5:3 }\end{array}$ \\
\hline 23 & $\begin{array}{l}\text { Brass spring-cover brooch. } \\
\text { Type close to A.II.28-29. } \\
\text { From the foot. }\end{array}$ & $\begin{array}{l}\text { stray find } \\
(2497) \\
\text { phase B2a- } \\
\text { B2b }\end{array}$ & 16151 & 81,1 & 0,16 & 0 & 0,07 & 0 & 0 & 0,25 & 0,19 & 16,1 & 0,03 & 0 & 1,2 & 0,03 & 0,74 & 0 & 0,03 & 0,11 & unpublished \\
\hline 24 & $\begin{array}{l}\text { Brass spring-cover brooch. } \\
\text { Type A.II. } 40-41 . \\
\text { From the bow. }\end{array}$ & $\begin{array}{c}\text { stray find } \\
(2523) \\
\text { phase B2/C1- } \\
\text { C1a }\end{array}$ & 16155 & 83,95 & 0,11 & 0,3 & 0 & 0,04 & 0 & 0,86 & 0,21 & 11,7 & 0 & 0,15 & 1,47 & 0,06 & 0,12 & 0 & 0,22 & 0,82 & $\begin{array}{l}\text { Natuniewicz-Sekuła } \\
2010,413 \text {, fig. } 9: 3\end{array}$ \\
\hline 25 & $\begin{array}{l}\text { Brass spring-covered brooch, } \\
\text { decorated with beaded wire on } \\
\text { the bow crest. } \\
\text { Type A.II.38/40-41. } \\
\text { From the bow. } \\
\text { The results of analysis other } \\
\text { parts, see Table 2:90. }\end{array}$ & $\begin{array}{l}502 \\
(2586) \\
\text { stadium } \\
\text { IIB/IIC }\end{array}$ & 16156 & 84,32 & 0,01 & 0,01 & 0,04 & 0 & 0 & 1,44 & 0,07 & 7,33 & 0,41 & 0,55 & 3,88 & 0,21 & 1,63 & 0 & 0,08 & 0 & unpublished \\
\hline 26 & $\begin{array}{l}\text { Tin-lead bronze lunula mounting } \\
\text { (from wooden bucket or casket). } \\
\text { From the central part. }\end{array}$ & $\begin{array}{l}498 \mathrm{~A} \\
(2594) \\
\text { stadium } \mathrm{V}\end{array}$ & 16157 & 85,86 & 0,02 & 0,04 & 0 & 0 & 0 & 0,24 & 0,12 & 0,3 & 0,37 & 0,21 & 10,89 & 0,31 & 1,41 & 0 & 0,01 & 0,22 & unpublished \\
\hline 27 & $\begin{array}{l}\text { Tin-lead bronze lunula mounting } \\
\text { (from wooden bucket or casket). } \\
\text { From the ring (handle) of } \\
\text { mounting. }\end{array}$ & $\begin{array}{c}4988 \mathrm{~A} \\
(2594) \\
\text { stadium V }\end{array}$ & 16157,01 & 83,26 & 0,24 & 0 & 0 & 0 & 0,06 & 0,5 & 0,14 & 1,85 & 0,05 & 0,32 & 7,21 & 0,41 & 5,85 & 0 & 0 & 0,13 & unpublished \\
\hline
\end{tabular}




\begin{tabular}{|c|c|c|c|c|c|c|c|c|c|c|c|c|c|c|c|c|c|c|c|c|c|}
\hline 28 & $\begin{array}{l}\text { Brass brooch, with tin coating } \\
\text { on the bow. } \\
\text { Type A.V, series } 11, \text { type } \\
\text { Leonów after Jamka. } \\
\text { The bottom side of the bow. }\end{array}$ & $\begin{array}{c}\text { stray find } \\
(2569) \\
\text { phase B2b- } \\
\text { B2c }\end{array}$ & 16158 & 85,43 & 0,11 & 0,29 & 0 & 0,07 & 0,04 & 0,32 & 0 & 10,31 & 0 & 0,23 & 1,92 & 0,04 & 1,26 & 0 & 0 & 0 & Fig. 8:3 \\
\hline 29 & $\begin{array}{l}\text { Brass brooch, with tin coating } \\
\text { on the bow. } \\
\text { Type A.V, series } 11 \text {, type } \\
\text { Leonów after Jamka. } \\
\text { The tin coating on the bow. }\end{array}$ & $\begin{array}{c}\text { stray find } \\
(2569) \\
\text { phase B2b- } \\
\text { B2c } \\
\end{array}$ & 16158,01 & 27,2 & 0,24 & 0,55 & 0,48 & 0,06 & 0,01 & 0,34 & 0,19 & 0,42 & 0 & 0,78 & 68,39 & 0 & 1,36 & 0 & 0 & 0 & Fig. 8:3 \\
\hline 30 & $\begin{array}{l}\text { Brass brooch. } \\
\text { Type close to A.V.118. } \\
\text { From the catchplate soldered } \\
\text { separate to the bow. }\end{array}$ & $\begin{array}{c}505 \\
(2627) \\
\text { stadium } \\
\text { IIIA/IIIB }\end{array}$ & 16159 & 84,52 & 0,11 & 0,02 & 0 & 0 & 0 & 0,6 & 0,16 & 10,34 & 0 & 0,11 & 2,44 & 0 & 1,62 & 0 & 0,07 & 0 & unpublished \\
\hline 31 & $\begin{array}{l}\text { Copper fragment of vessels?. } \\
\text { From the central part. }\end{array}$ & $\begin{array}{c}499 \\
(2632) \\
\text { stadium IIIA }\end{array}$ & 16161 & 99,6 & 0,09 & 0 & 0 & 0,08 & 0 & 0 & 0 & 0,12 & 0,05 & 0 & 0 & 0 & 0,05 & 0 & 0,02 & 0 & unpublished \\
\hline 32 & $\begin{array}{l}\text { Brass pear shape pendant. } \\
\text { From the body of the pendant. }\end{array}$ & $\begin{array}{l}519 \\
(2641) \\
\text { stadium } \\
\text { IVB } / V\end{array}$ & 16162 & 90,02 & 0,15 & 0 & 0 & 0 & 0 & 0,26 & 0,08 & 2,82 & 0 & 0,06 & 3,17 & 0,41 & 3,03 & 0 & 0 & 0 & Fig. 5:8 \\
\hline 33 & $\begin{array}{l}\text { Tin bronze fragments of strainer. } \\
\text { Type Eggers } 160 / 161 \text {. } \\
\text { From the fragent of the body. }\end{array}$ & $\begin{array}{c}\text { stray find } \\
(2702) \\
\text { phase B2/C1- } \\
\text { Cla }\end{array}$ & 16164 & 86,83 & 0,22 & 0 & 0,02 & 0,03 & 0,04 & 0,15 & 0,15 & 0,32 & 0 & 0,08 & 10,96 & 0,21 & 0,98 & 0 & 0 & 0 & $\begin{array}{l}\text { Natuniewicz-Sekula } \\
\text { 2010, } 415 \text {, fig. 12:56-57. } \\
\text { Fig. } 6: 3\end{array}$ \\
\hline 34 & $\begin{array}{l}\text { Brass heel band spur. } \\
\text { Type Ginalski subgroup F3a. } \\
\text { From the prick. }\end{array}$ & $\begin{array}{c}15 \\
(47) \\
\text { stadium IVA }\end{array}$ & 16184 & 86,11 & 0,05 & 0 & 0,09 & 0 & 0 & 0,38 & 0,07 & 9 & 0 & 0,16 & 1,73 & 0,25 & 2,15 & 0 & 0 & 0,01 & $\begin{array}{l}\text { Natuniewicz-Sekula, } \\
\text { Okulicz-Kozaryn 2011, } \\
\text { 28, pl. III:8 }\end{array}$ \\
\hline 35 & $\begin{array}{l}\text { Brass heel band spur. } \\
\text { Type Ginalski subgroup F3/F4. } \\
\text { From the prick. }\end{array}$ & $\begin{array}{c}82 \\
(325) \\
\text { stadium IVA }\end{array}$ & 16185 & 87,17 & 0,01 & 0 & 0 & 0,07 & 0,04 & 0,7 & 0,11 & 6,07 & 0,02 & 0,09 & 2,58 & 0,42 & 2,49 & 0 & 0,1 & 0,12 & $\begin{array}{l}\text { Natuniewicz-Sekula, } \\
\text { Okulicz-Kozaryn 2011, } \\
\text { 42, pl. XXXIV:4 }\end{array}$ \\
\hline 36 & $\begin{array}{l}\text { Brass cylindrical box with lid. } \\
\text { From side of the box. }\end{array}$ & $\begin{array}{c}34 \\
(131) \\
\text { stadium V }\end{array}$ & 16186 & 86,69 & 0,03 & 0,15 & 0,06 & 0 & 0 & 0,56 & 0,16 & 7,35 & 0,12 & 0,19 & 1,97 & 0,06 & 2,63 & 0 & 0,02 & 0 & $\begin{array}{l}\text { Natuniewicz-Sekula, } \\
\text { Okulicz-Kozaryn 2011, } \\
\text { 33, pl. XV:4 }\end{array}$ \\
\hline 37 & $\begin{array}{l}\text { Brass cylindrical box with lid } \\
\text { The outside of the lid. }\end{array}$ & $\begin{array}{c}34 \\
(131) \\
\text { stadium V }\end{array}$ & 16186,01 & 88,38 & 0,07 & 0,21 & 0,14 & 0 & 0 & 0,29 & 0,17 & 4,05 & 0,34 & 0,35 & 2,87 & 0,12 & 3,02 & 0 & 0 & 0 & $\begin{array}{l}\text { Natuniewicz-Sekula, } \\
\text { Okulicz-Kozaryn 2011, } \\
\text { 33, pl. XV:4 }\end{array}$ \\
\hline 38 & $\begin{array}{l}\text { Brass cylindrical box with } \\
\text { recessed did. } \\
\text { From side of the box. }\end{array}$ & $\begin{array}{c}174 \\
(747) \\
\text { stadium V }\end{array}$ & 16187 & 74,84 & 0 & 0,05 & 0 & 0 & 0,07 & 0,23 & 0 & 22,29 & 0 & 0 & 1,43 & 0,15 & 0,94 & 0 & 0 & 0 & $\begin{array}{l}\text { Natuniewicz-Sekuła, } \\
\text { Okulicz-Kozaryn 2011, } \\
\text { 60, pl. LXXI:6. } \\
\text { Fig. 5:10 }\end{array}$ \\
\hline 39 & $\begin{array}{l}\text { Brass cylindrical box with } \\
\text { recessed lid. } \\
\text { The inner side of the lid. }\end{array}$ & $\begin{array}{c}174 \\
(747) \\
\text { stadium V }\end{array}$ & 16187,01 & 77,02 & 0,12 & 0,08 & 0,14 & 0,33 & 0 & 0,2 & 0 & 17,29 & 0,04 & 0 & 3,2 & 0,27 & 1,04 & 0 & 0,14 & 0,13 & $\begin{array}{l}\text { Natuniewicz-Sekula, } \\
\text { Okulicz-Kozaryn 2011, } \\
\text { 60, pl. LXXI:6. } \\
\text { Fig. 5:10 }\end{array}$ \\
\hline
\end{tabular}




\begin{tabular}{|c|c|c|c|c|c|c|c|c|c|c|c|c|c|c|c|c|c|c|c|c|c|}
\hline 40 & $\begin{array}{l}\text { Brass cylindrical box with } \\
\text { comprising lid. } \\
\text { The inner side of the lid. }\end{array}$ & $\begin{array}{c}379 \\
(2156) \\
\text { stadium V }\end{array}$ & 16188 & 87,04 & 0,06 & 0 & 0,1 & 0 & 0,04 & 0,36 & 0,05 & 0,85 & 0 & 0,06 & 3,34 & 0 & 7,62 & 0 & 0,47 & 0 & $\begin{array}{l}\text { Natuniewicz-Sekula, } \\
\text { Okulicz-Kozaryn 2011, } \\
\text { 99, pl. CLXVII:5 }\end{array}$ \\
\hline 41 & $\begin{array}{l}\text { Brass barrel solid bead. } \\
\text { Type close to T-M } 520 . \\
\text { From the bead body. }\end{array}$ & $\begin{array}{c}379 \\
(1929) \\
\text { stadium V }\end{array}$ & 16189 & 95,22 & 0,04 & 0,01 & 0 & 0 & 0,04 & 0 & 0,15 & 0,33 & 0,11 & 0,07 & 0,06 & 0 & 2,94 & 0 & 1,03 & 0 & $\begin{array}{l}\text { Natuniewicz-Sekula, } \\
\text { Okulicz-Kozaryn 2011, } \\
\text { 99, pl. CLXVIII:379/7 }\end{array}$ \\
\hline 42 & $\begin{array}{l}\text { Brass barrel bead, hollow inside, } \\
\text { ornamented engraved lines. } \\
\text { Type close to } 520 . \\
\text { From the bead body. }\end{array}$ & $\begin{array}{c}150 \\
(588) \\
\text { stadium } \\
\text { IVA/IVB }\end{array}$ & 16190 & 88,65 & 0,02 & 0 & 0 & 0,04 & 0,01 & 0,49 & 0,2 & 4,99 & 0,16 & 0 & 3,11 & 0,14 & 2,2 & 0 & 0 & 0 & $\begin{array}{l}\text { Natuniewicz-Sekuta, } \\
\text { Okunicz-Kozaryn 2011, } \\
56, \text { pl. LVIII:25. } \\
\text { Fig. 5:9 }\end{array}$ \\
\hline 43 & $\begin{array}{l}\text { Brass strap end fitting. } \\
\text { Type close to R O3. } \\
\text { From the fitting shaft. }\end{array}$ & $\begin{array}{c}14 \\
(13) \\
\text { stadium IB }\end{array}$ & 16191 & 79,86 & 0,15 & 0,2 & 0,06 & 0 & 0 & 0,79 & 0 & 14,48 & 0 & 0,01 & 3,81 & 0 & 0,62 & 0 & 0,01 & 0 & $\begin{array}{l}\text { Natuniewicz-Sekuła, } \\
\text { Okulicz-Kozaryn 2011, } \\
\text { 27, pl. II:14/1. } \\
\text { Fig. 5:5 }\end{array}$ \\
\hline 44 & $\begin{array}{l}\text { Brass triple-crest brooch with } \\
\text { traces of silver foil. } \\
\text { Type A.V. } 96 \text {. } \\
\text { The middle crest on the bow. }\end{array}$ & $\begin{array}{l}25 \\
(70) \\
\text { stadium } \\
\text { IIB/IIC }\end{array}$ & 16193 & 80,68 & 0,16 & 0,14 & 0,11 & 0 & 0,06 & 0,85 & 0,1 & 8,26 & 0,33 & 0,92 & 5,32 & 0,3 & 2,65 & 0 & 0,12 & 0 & $\begin{array}{l}\text { Natuniewicz-Sekuła, } \\
\text { Okulicz-Kozaryn 2011, } \\
\text { 30, pl. VII:25/1 }\end{array}$ \\
\hline 45 & $\begin{array}{l}\text { Brass crest-headed brooch. } \\
\text { Type A.V.128. } \\
\text { The bottom side of the bow. }\end{array}$ & $\begin{array}{l}25 \\
(73) \\
\text { stadium } \\
\text { IIB/IIC }\end{array}$ & 16194 & 86,77 & 0,09 & 0,03 & 0,13 & 0,02 & 0 & 0,62 & 0 & 8,11 & 0,38 & 0,07 & 1,68 & 0,19 & 1,85 & 0 & 0,07 & 0 & $\begin{array}{l}\text { Natuniewicz-Sekuła, } \\
\text { Okulicz-Kozaryn 2011, } \\
\text { 30, pl. VII:25/3 }\end{array}$ \\
\hline 46 & $\begin{array}{l}\text { Brass knee brooch. } \\
\text { Type with features A.V. } 132 \text { and } \\
\text { A.V. } 137 \text {. } \\
\text { From the catchplate of a brooch. }\end{array}$ & $\begin{array}{c}83 \\
\left(\begin{array}{l}869) \\
\text { stadium IIB }\end{array}\right.\end{array}$ & 16195 & 86,52 & 0,15 & 0 & 0 & 0,05 & 0,04 & 0,73 & 0 & 7,73 & 0 & 0 & 3,32 & 0 & 1,47 & 0 & 0 & 0 & $\begin{array}{l}\text { Natuniewicz-Sekuła, } \\
\text { Okulicz-Kozaryn 2011, } \\
\text { 42, pl. XXX:85/1 }\end{array}$ \\
\hline 47 & $\begin{array}{l}\text { Brass capsule pendant with } \\
\text { traces silver gilded foil. } \\
\text { The bottom shield of the } \\
\text { capsule. }\end{array}$ & $\begin{array}{l}278 \\
(1305) \\
\text { stadium } \\
\text { IIB/IIC }\end{array}$ & 16196 & 93,6 & 0,1 & 0 & 0,09 & 0,02 & 0 & 0,2 & 0,01 & 0 & 0 & 0,11 & 4,99 & 0 & 0,87 & 0 & 0 & 0 & $\begin{array}{l}\text { Natuniewicz-Sekuła, } \\
\text { Okulicz-Kozaryn 2011, } \\
\text { 81, pl. CXXII:278/1. } \\
\text { Fig. 5:7 }\end{array}$ \\
\hline 48 & $\begin{array}{l}\text { Brass capsule pendant, } \\
\text { decorated silver gilded foil. } \\
\text { The top shield of the capsule. } \\
\text { The results of analysis other } \\
\text { parts, see Table 1:33. }\end{array}$ & $\begin{array}{l}278 \\
(1313) \\
\text { stadium } \\
\text { IIB/IIC }\end{array}$ & 16197 & 92,93 & 0,01 & 0 & 0 & 0,03 & 0 & 0,12 & 0,07 & 0,31 & 0,14 & 0,07 & 5,56 & 0,5 & 0,26 & 0 & 0 & 0,01 & $\begin{array}{l}\text { Natuniewicz-Sekula, } \\
\text { Okulicz-Kozaryn 2011, } \\
\text { 81, pl. CXXII:278/2 }\end{array}$ \\
\hline 49 & $\begin{array}{l}\text { Tin-lead bronze brooch } \\
\text { derivative of strongly profiled } \\
\text { forms. } \\
\text { Type close to A.IV. } 84 \text {. } \\
\text { The catchplate of the brooch. }\end{array}$ & $\begin{array}{l}364 \\
(1760) \\
\text { stadium } \\
\text { IIB/IIC }\end{array}$ & 16198 & 79,98 & 0,22 & 0,01 & 0,08 & 0 & 0,07 & 0,25 & 0 & 0,27 & 0 & 1,13 & 9,65 & 0,26 & 7,84 & 0 & 0 & 0,23 & $\begin{array}{l}\text { Natuniewicz-Sekula, } \\
\text { Okulicz-Kozaryn 2011, } \\
\text { 97, pl. CLIV:364/2 }\end{array}$ \\
\hline 50 & $\begin{array}{l}\text { Tin-lead bronze coin (denarius } \\
\text { subearate of Trajan). } \\
\text { Tin coating on the observe of } \\
\text { the coin. }\end{array}$ & $\begin{array}{c}379 \\
(2156) \\
\text { stadium V }\end{array}$ & 16199 & 27,18 & 0,55 & 1,26 & 0,57 & 0 & 0,25 & 0,33 & 0,03 & 0,06 & 0,5 & 1,1 & 47,09 & 0,47 & 20,05 & 0 & 0,55 & 0 & $\begin{array}{l}\text { Natuniewicz-Sekuła, } \\
\text { Okulicz-Kozaryn 2011, } \\
\text { 99, pl. CLXVII:6. } \\
\text { Fig. 6:4 }\end{array}$ \\
\hline 51 & $\begin{array}{l}\text { Tin-lead bronze coin (denarius } \\
\text { subaerate of Trajan). } \\
\text { The borehole in the center of the } \\
\text { coin. }\end{array}$ & $\begin{array}{c}379 \\
(2156) \\
\text { stadium V }\end{array}$ & 16199,01 & 74,91 & 0,53 & 0,14 & 0,01 & 0,02 & 0,07 & 0,13 & 0,23 & 0,09 & 0,16 & 0,04 & 19,86 & 0 & 3,82 & 0 & 0 & 0 & $\begin{array}{l}\text { Natuniewicz-Sekuła, } \\
\text { Okulicz-Kozaryn 2011, } \\
\text { 99, pl. CLXVII:6. } \\
\text { Fig. 6:4 }\end{array}$ \\
\hline
\end{tabular}




\begin{tabular}{|c|c|c|c|c|c|c|c|c|c|c|c|c|c|c|c|c|c|c|c|c|c|}
\hline 52 & $\begin{array}{l}\text { Tin-lead bronze coin (denarius } \\
\text { subaerate of Trajan). } \\
\text { The borehole the side of the } \\
\text { coin. }\end{array}$ & $\begin{array}{c}379 \\
(2156) \\
\text { stadium V }\end{array}$ & 16199,02 & 68,84 & 0,87 & 0,05 & 0,11 & 0 & 0,08 & 0,41 & 0 & 0,11 & 0,12 & 0,29 & 19,15 & 0 & 9,67 & 0 & 0 & 0,3 & $\begin{array}{l}\text { Natuniewicz-Sekuła, } \\
\text { Okulicz-Kozaryn 2011, } \\
\text { 99, pl. CLXVII:6. } \\
\text { Fig. 6:4 }\end{array}$ \\
\hline 53 & $\begin{array}{l}\text { Tin-lead bronze coin (denarius } \\
\text { subaerate of Trajan). } \\
\text { The bottom layer of tin coating } \\
\text { on the observe. } \\
\text { The platinum content was } \\
\text { detected } \mathrm{Pt}=0,82 \text {. }\end{array}$ & $\begin{array}{c}379 \\
(2156) \\
\text { stadium V }\end{array}$ & 16199,03 & 69,85 & 0 & 0,2 & 0 & 0 & 0,01 & 0,13 & 0 & 0 & 0 & 0,21 & 23,17 & 1,02 & 4,41 & 0 & 0 & 0,18 & $\begin{array}{l}\text { Natuniewicz-Sekuła, } \\
\text { Okulicz-Kozaryn 2011, } \\
\text { 99, pl. CLXVII:6. } \\
\text { Fig. 6:4 }\end{array}$ \\
\hline 54 & $\begin{array}{l}\text { Tin-lead bronze coin (denarius } \\
\text { subaerate of Antoninus Pius for } \\
\text { Faustina I, with ring for } \\
\text { suspension. } \\
\text { The bottom layer of tin coating } \\
\text { on the observe. }\end{array}$ & $\begin{array}{c}141 \\
(566) \\
\text { stadium V }\end{array}$ & 16200 & 58,45 & 0,09 & 0,21 & 0,27 & 0,07 & 0 & 0,17 & 0,03 & 2,44 & 0,45 & 0,04 & 20,94 & 1,4 & 15,44 & 0 & 0 & 0 & $\begin{array}{l}\text { Natuniewicz-Sekuła, } \\
\text { Otulicz-Kozaryn 2011, } \\
\text { 53, pl. LIV:141/5. } \\
\text { Fig. 6:5 }\end{array}$ \\
\hline 55 & $\begin{array}{l}\text { Tin-lead bronze coin (denarius } \\
\text { subaerate of Antoninus Pius for } \\
\text { Mark Aurelius. } \\
\text { The borehole in the center of } \\
\text { the coin. }\end{array}$ & $\begin{array}{c}141 \\
(566) \\
\text { stadium V }\end{array}$ & 16201 & 74,89 & 1,28 & 2,89 & 0,11 & 0,02 & 0 & 2,2 & 0,69 & 3,34 & 0,43 & 0,41 & 3,77 & 0 & 9,73 & 0 & 0,25 & 0 & $\begin{array}{l}\text { Natuniewicz-Sekuła, } \\
\text { Okulicz-Kozaryn 2011, } \\
\text { 53, pl. LIV:141/4. } \\
\text { Fig. 6:6 }\end{array}$ \\
\hline 56 & $\begin{array}{l}\text { Tin-lead bronze coin (denarius } \\
\text { subaerate of Antoninus Pius for } \\
\text { Mark Aurelius. } \\
\text { The tin coating on the observe. }\end{array}$ & $\begin{array}{c}141 \\
(566) \\
\text { stadium V }\end{array}$ & 16201,01 & 49,55 & 0,32 & 0,65 & 0,5 & 0 & 0,14 & 0,73 & 0,1 & 0,44 & 0,11 & 0,39 & 41,58 & 0,36 & 5,12 & 0 & 0 & 0 & $\begin{array}{l}\text { Natuniewicz-Sekula, } \\
\text { Okulicz-Kozaryn 2011, } \\
\text { 53, pl. LIV:141/4. } \\
\text { Fig. 6:6 }\end{array}$ \\
\hline 57 & $\begin{array}{l}\text { Brass ring of } 1 \frac{1}{2} \text { coils, with } \\
\text { turned out ends. } \\
\text { From the wire of the ring. }\end{array}$ & $\begin{array}{c}141 \\
(566) \\
\text { stadium V }\end{array}$ & 16202 & 89,2 & 0,08 & 0,05 & 0,14 & 0,23 & 0,01 & 0,23 & 0 & 3,41 & 0,26 & 0 & 3,75 & 0,67 & 1,97 & 0 & 0 & 0 & $\begin{array}{l}\text { Natuniewicz-Sekuła, } \\
\text { Okulicz-Kozaryn 2011, } \\
\text { 53, pl. LIV:141/7. }\end{array}$ \\
\hline 58 & $\begin{array}{l}\text { Brass brooch. } \\
\text { Type A.V.148. } \\
\text { From the bow. }\end{array}$ & $\begin{array}{l}398 \\
\text { (1987) } \\
\text { stadium } \\
\text { IIB/IIC }\end{array}$ & 16203 & 81,38 & 0,08 & 0,01 & 0,09 & 0 & 0,24 & 0,56 & 0,08 & 12,21 & 0,02 & 0,04 & 4,85 & 0 & 0,45 & 0 & 0 & 0 & $\begin{array}{l}\text { Natuniewicz-Sekuła, } \\
\text { Okulicz-Kozaryn 2011, } \\
\text { 103, pl. } \\
\text { CLXXVII:398/3 }\end{array}$ \\
\hline 59 & $\begin{array}{l}\text { Brass crest-headed brooch. } \\
\text { Type close to A.V. } 120 . \\
\text { From the bow. }\end{array}$ & $\begin{array}{l}267 \\
(1169) \\
\text { stadium } \\
\text { IIB/IIC }\end{array}$ & 16204 & 80,67 & 0,11 & 0,01 & 0 & 0,07 & 0 & 0,27 & 0,05 & 17,09 & 0 & 0,25 & 1,09 & 0,06 & 0,09 & 0 & 0,08 & 0,17 & $\begin{array}{l}\text { Natuniewicz-Sekuła, } \\
\text { Otulicz-Kozaryn 2011, } \\
\text { 78, pl. CXIII:3 }\end{array}$ \\
\hline 60 & $\begin{array}{l}\text { Brass brooch decorated silver } \\
\text { foil. } \\
\text { Type A.V, series } 11 \text { or type } \\
\text { Leonów after Jamka. } \\
\text { From the bow. } \\
\text { The results of analysis other } \\
\text { parts, see Table 2:102. }\end{array}$ & $\begin{array}{l}267 \\
(1161) \\
\text { stadium } \\
\text { IIB/IIC }\end{array}$ & 16205 & 86,73 & 0,1 & 0,09 & 0,01 & 0 & 0,03 & 1,13 & 0,06 & 5,28 & 0 & 1,01 & 4,91 & 0,17 & 0,47 & 0 & 0 & 0 & $\begin{array}{l}\text { Natuniewicz-Sekula, } \\
\text { Okulicz-Kozaryn 2011, } \\
\text { 78, pl. CXIII:1 }\end{array}$ \\
\hline 61 & $\begin{array}{l}\text { Brass brooch decorated silver } \\
\text { foil. } \\
\text { Type A.V, series } 11 \text { or type } \\
\text { Leonów after Jamka. } \\
\text { From lower part of the bow. } \\
\text { The results of analysis other } \\
\text { parts, see Table 2:103. }\end{array}$ & $\begin{array}{l}267 \\
\text { (1165) } \\
\text { stadium } \\
\text { IIB/IIC }\end{array}$ & 16206 & 89,64 & 0,06 & 0 & 0 & 0 & 0,07 & 1,43 & 0 & 6,01 & 0 & 0,16 & 2,37 & 0,05 & 0,2 & 0 & 0 & 0 & $\begin{array}{l}\text { Natuniewicz-Sekula, } \\
\text { Okulicz--Kozaryn 2011, } \\
\text { 78, pl. CXIII:2 }\end{array}$ \\
\hline
\end{tabular}




\begin{tabular}{|c|c|c|c|c|c|c|c|c|c|c|c|c|c|c|c|c|c|c|c|c|c|}
\hline 62 & $\begin{array}{l}\text { Brass brooch with crests on head } \\
\text { and foot. } \\
\text { Elblag. Pole Nowomiejskie, } \\
\text { Elblag district. } \\
\text { Type close to A.V.110. } \\
\text { From the bow. }\end{array}$ & $\begin{array}{c}\text { no grave } \\
\text { number } \\
\text { (collections } \\
\text { of the } \\
\text { Museum of } \\
\text { Archaeology } \\
\text { and History } \\
\text { in Elblag, } \\
\text { inventory no. } \\
\text { 36/79) phase } \\
\text { B2b } \\
\end{array}$ & 16207 & 80,96 & 0,05 & 0,18 & 0 & 0 & 0 & 0,39 & 0,13 & 15 & 0,58 & 0 & 2,29 & 0,11 & 0,17 & 0 & 0 & 0,14 & $\begin{array}{l}\text { Natuniewicz 2000, 143, } \\
\text { pl. II:2 }\end{array}$ \\
\hline 63 & $\begin{array}{l}\text { Brass eye brooch. } \\
\text { Rubno Wielkie, Elblag district. } \\
\text { Type A.III.60. } \\
\text { From the bow. }\end{array}$ & $\begin{array}{c}\text { no grave } \\
\text { number } \\
\text { (collections } \\
\text { of the } \\
\text { Museum of } \\
\text { Archaeology } \\
\text { and History } \\
\text { in Elblag, } \\
\text { inventory no. } \\
\text { 68/175) } \\
\text { phase B2a } \\
\end{array}$ & 16208 & 78,93 & 0,13 & 0,07 & 0 & 0,02 & 0,04 & 0,16 & 0,03 & 20,06 & 0 & 0 & 0,37 & 0 & 0 & 0 & 0,02 & 0,16 & $\begin{array}{l}\text { Natuniewicz 2000, 154, } \\
\text { pl. III:10. } \\
\text { Fig. 5:1 }\end{array}$ \\
\hline 64 & $\begin{array}{l}\text { Brass bow of the crossbow } \\
\text { brooch (melted), preserved with } \\
\text { melted on it a lump or silver. } \\
\text { Elblag, Pole Nowomiejskie, } \\
\text { Elblag district. } \\
\text { Type A.VI.167. } \\
\text { From upper part of the bow. } \\
\text { The results of analysis other } \\
\text { parts, see Table 2:104. }\end{array}$ & $\begin{array}{c}\text { no grave } \\
\text { number } \\
\text { (collections } \\
\text { of the } \\
\text { Museum of } \\
\text { Archaeology } \\
\text { and History } \\
\text { in Elblag, } \\
\text { inventory no. } \\
181 / 478 \text { ) } \\
\text { phase C1b to } \\
\text { the beginning } \\
\text { C2 }\end{array}$ & 16209 & 88,59 & 0 & 0,05 & 0,07 & 0 & 0 & 0,25 & 0,1 & 9,04 & 0,14 & 0,24 & 0,63 & 0,13 & 0,67 & 0 & 0,09 & 0 & $\begin{array}{l}\text { Natuniewicz 2000, 143, } \\
\text { pl.II:7 }\end{array}$ \\
\hline 65 & $\begin{array}{l}\text { Brass brooch with cylinder for } \\
\text { the spring. } \\
\text { Rubno Wielkie, Elblag district. } \\
\text { Type A.V.114. } \\
\text { From the bow. }\end{array}$ & $\begin{array}{c}\text { no grave } \\
\text { number } \\
\text { (collections } \\
\text { of the } \\
\text { Museum of } \\
\text { Archaeology } \\
\text { and History } \\
\text { in Elblag, } \\
\text { inventory no. } \\
239 / / 555 \text { ) } \\
\text { phase B2b }\end{array}$ & 16210 & 80,61 & 0,1 & 0 & 0 & 0 & 0 & 0,5 & 0 & 14,07 & 0 & 0,17 & 2,69 & 0 & 1,85 & 0 & 0 & 0 & $\begin{array}{l}\text { Natuniewicz 2000, 154, } \\
\text { pl. III:9. }\end{array}$ \\
\hline 66 & $\begin{array}{l}\text { Brass spring-cover brooch. } \\
\text { Elblag. Pole Nowomiejskie or } \\
\text { Elblag. Moniuszki street, Elblag } \\
\text { district. } \\
\text { Type A.II.40-41. } \\
\text { From the bow. }\end{array}$ & $\begin{array}{c}\text { no grave } \\
\text { number } \\
\text { (collections } \\
\text { of the } \\
\text { Museum of } \\
\text { Archaeology } \\
\text { and History } \\
\text { in Elblag, } \\
\text { inventory no. } \\
\text { 1/3) } \\
\text { phase B2/C1- } \\
\text { Cla. }\end{array}$ & 16211 & 87,2 & 0,07 & 0,07 & 0 & 0 & 0 & 0,59 & 0,06 & 10,95 & 0 & 0,11 & 0,35 & 0,47 & 0 & 0 & 0,13 & 0 & $\begin{array}{l}\text { Natuniewicz 2000, 148, } \\
\text { pl. V:11. }\end{array}$ \\
\hline
\end{tabular}




\begin{tabular}{|c|c|c|c|c|c|c|c|c|c|c|c|c|c|c|c|c|c|c|c|c|c|}
\hline 67 & $\begin{array}{l}\text { Fragment of brass spring-cover } \\
\text { brooch. } \\
\text { Elblag. Pole Nowomiejskie or } \\
\text { Elblag. Moniuszki street, Elblag } \\
\text { district. } \\
\text { Type A.II.40-41. } \\
\text { The outer side of the bow. }\end{array}$ & $\begin{array}{c}\text { no grave } \\
\text { number } \\
\text { (collections } \\
\text { of the } \\
\text { Museum of } \\
\text { Archaeology } \\
\text { and History } \\
\text { in Elblag, } \\
\text { inventory no. } \\
\text { 40/101) phase } \\
\text { B2/C1-Cla. }\end{array}$ & 16212 & 83,73 & 0,03 & 0,03 & 0 & 0 & 0 & 0,59 & 0,2 & 10,56 & 0,43 & 0,17 & 3,33 & 0,31 & 0,57 & 0 & 0,05 & 0 & $\begin{array}{l}\text { Natuniewicz 2000, 148, } \\
\text { pl. VI:2. } \\
\text { Fig. 11:1 }\end{array}$ \\
\hline 68 & $\begin{array}{l}\text { Fragment of brass spring-cover } \\
\text { brooch. } \\
\text { Elblag. Pole Nowomiejskie or } \\
\text { Elblag. Moniuszki street, Elblag } \\
\text { district. } \\
\text { Type A.II.40-41. } \\
\text { The inner side of the bow. }\end{array}$ & 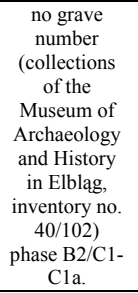 & 16213 & 81,89 & 0 & 0,03 & 0,01 & 0,01 & 0,09 & 0,29 & 0 & 14,59 & 0 & 0 & 2,26 & 0,3 & 0,4 & 0 & 0,13 & 0 & $\begin{array}{l}\text { Natuniewicz 2000, 148, } \\
\text { pl. VI:1.: } \\
\text { Fig. 11:2 }\end{array}$ \\
\hline 69 & $\begin{array}{l}\text { Brass brooch with massive crest } \\
\text { on the head. } \\
\text { Elblag. Pole Nowomiejskie or } \\
\text { Elblag. Moniuszki street, Elblag } \\
\text { district. } \\
\text { Type A.V. } 126 \text {. } \\
\text { From the bow. }\end{array}$ & $\begin{array}{c}\text { no grave } \\
\text { number } \\
\text { (collections } \\
\text { of the } \\
\text { Museum of } \\
\text { Archaeology } \\
\text { and History } \\
\text { in Elblag, } \\
\text { inventory no. } \\
\text { 36/68). phase } \\
\text { B2/C1-Cla } \\
\end{array}$ & 16214 & 83,82 & 0,13 & 0,02 & 0,08 & 0 & 0 & 0,72 & 0 & 3,69 & 0 & 0 & 8,21 & 0 & 3,33 & 0 & 0 & 0 & $\begin{array}{l}\text { Natuniewicz 2000, 149, } \\
\text { pl. VI:9. }\end{array}$ \\
\hline 70 & $\begin{array}{l}\text { Fragment of brass spring-cover } \\
\text { brooch. } \\
\text { Elblag. Pole Nowomiejkkie or } \\
\text { Elblag. Moniuszki street, Elblag } \\
\text { district. } \\
\text { Type A.II.40-41. } \\
\text { From crest on the bow. }\end{array}$ & $\begin{array}{l}\text { no grave } \\
\text { number } \\
\text { (collections } \\
\text { of the } \\
\text { Museum of } \\
\text { Archaeology } \\
\text { and History } \\
\text { in Elblag, } \\
\text { inventory no. } \\
\text { 39/98) phase } \\
\text { B2/C1-Cla. }\end{array}$ & 16215 & 84,95 & 0,13 & 0,11 & 0,09 & 0,06 & 0 & 0,45 & 0,16 & 4,64 & 0 & 0,27 & 3,15 & 0,03 & 5,96 & 0 & 0 & 0 & $\begin{array}{l}\text { Natuniewicz 2000, 148, } \\
\text { pl. V:6. }\end{array}$ \\
\hline 71 & $\begin{array}{l}\text { Brass brooch with half cylinder } \\
\text { for the spring. } \\
\text { Elblag. Pole Nowomiejskie or } \\
\text { Elblag. Moniuszki street, Elblag } \\
\text { district. } \\
\text { Type A.II.42. } \\
\text { From the bow. }\end{array}$ & 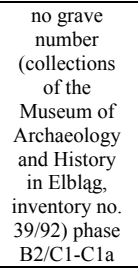 & 16216 & 82,47 & 0,05 & 0,07 & 0,02 & 0,2 & 0,09 & 0,29 & 0,2 & 10,8 & 0,03 & 0,26 & 5,2 & 0 & 0,02 & 0 & 0,3 & 0 & $\begin{array}{l}\text { Natuniewicz 2000, 149, } \\
\text { pl. VII:2. }\end{array}$ \\
\hline 72 & $\begin{array}{l}\text { Brass heel-band spur. } \\
\text { Type Ginalski subgroup E2. } \\
\text { From the prick. }\end{array}$ & $\begin{array}{c}521 \\
(2669) \\
\text { stadium }\end{array}$ & 16218 & 88,23 & 0,08 & 0,12 & 0,05 & 0 & 0,09 & 0,3 & 0,01 & 9,4 & 0 & 0,08 & 0,55 & 0 & 0,8 & 0 & 0,3 & 0 & $\begin{array}{l}\text { Kontny, Natuniewicz- } \\
\text { Sekuta 2010, 342, fig. } \\
\text { 1:521/2. Fig. 5:6 }\end{array}$ \\
\hline
\end{tabular}




\begin{tabular}{|c|c|c|c|c|c|c|c|c|c|c|c|c|c|c|c|c|c|c|c|c|c|}
\hline 73 & $\begin{array}{l}\text { Brass eye brooch. } \\
\text { Type A.III.57. } \\
\text { From the bow. }\end{array}$ & $\begin{array}{l}\text { stray find } \\
\text { (2902) phase } \\
\text { B2a }\end{array}$ & 16219 & 75,41 & 0,04 & 0,07 & 0,07 & 0,03 & 0,1 & 0,37 & 0,07 & 22,52 & 0,24 & 0 & 0,66 & 0,03 & 0,31 & 0 & 0,07 & 0 & unpublished \\
\hline 74 & $\begin{array}{l}\text { Tin-lead bronze knee brooch } \\
\text { with a distinct crest on the head. } \\
\text { Type close to Jobst } 13 \mathrm{C} / \mathrm{D} \text {. } \\
\text { From the catchplate of a brooch. }\end{array}$ & $\begin{array}{c}\text { stray find } \\
(2959) \\
\text { phase B2/C1- } \\
\text { Cla }\end{array}$ & 16220 & 86,52 & 0,15 & 0,03 & 0 & 0,03 & 0 & 0,07 & 0,11 & 0,42 & 0,06 & 0,01 & 5,11 & 0 & 7,49 & 0 & 0 & 0 & Fig. 6:2 \\
\hline 75 & $\begin{array}{l}\text { Brass brooch derivative of } \\
\text { strongly profiled forms. } \\
\text { Type A.IV, series } 2 \text {, or 1A(a) } \\
\text { after Dabrowska } \\
\text { From the catchplate. }\end{array}$ & $\begin{array}{l}\text { stray find } \\
(2777) \\
\text { phase B2b }\end{array}$ & 16221 & 86,37 & 0,01 & 0,12 & 0 & 0 & 0,1 & 0,2 & 0,27 & 9,39 & 0,45 & 0,05 & 1,7 & 0 & 1,33 & 0 & 0 & 0 & unpublished \\
\hline 76 & $\begin{array}{l}\text { Brass massive bead, hollow, } \\
\text { made of two domes ornamented } \\
\text { with geometric patterns. Type } \\
\text { close to T-M } 521 . \\
\text { From the dome. }\end{array}$ & $\begin{array}{c}536 \\
(2829) \\
\text { stadium } \\
\text { IIIA/IIIB }\end{array}$ & 16222 & 82,33 & 0 & 0,04 & 0,01 & 0,04 & 0 & 0,47 & 0,11 & 14,86 & 0,24 & 0 & 1,23 & 0 & 0,66 & 0 & 0 & 0 & $\begin{array}{l}\text { Natuniewicz-Sekuła } \\
2017,464,467 \text {; fig. } 2: 7, \\
5: 7\end{array}$ \\
\hline 77 & $\begin{array}{l}\text { Brass heel-band spur. } \\
\text { Type Ginalski subgroup E5. } \\
\text { From the prick. }\end{array}$ & $\begin{array}{c}521 \\
(2668) \\
\text { stadium IIIB }\end{array}$ & 16226 & 86,94 & 0,03 & 0 & 0 & 0,12 & 0 & 0,78 & 0,18 & 10,24 & 0 & 0,14 & 0,43 & 0,06 & 0,97 & 0 & 0,12 & 0 & $\begin{array}{l}\text { Kontny, Natuniewicz- } \\
\text { Sekuta } 2010,342 \text {, fig. } \\
\text { 1:521/1 }\end{array}$ \\
\hline
\end{tabular}


Table 4. Results of the chemical composition analyzes the solder binders (prepared by M. Natuniewicz-Sekuła)

\begin{tabular}{|c|c|c|c|c|c|c|c|c|c|c|c|c|c|c|c|c|c|c|c|}
\hline No. & $\begin{array}{l}\text { Description of the find/the } \\
\text { analyzed part of } \\
\text { find/Additional comments }\end{array}$ & $\begin{array}{c}\text { Grave no./ } \\
\text { inventory no./ } \\
\text { chronology }\end{array}$ & $\begin{array}{c}\text { Sample } \\
\text { no. }\end{array}$ & Au & $\mathrm{Si}$ & Al & $\mathrm{Cr}$ & Mn & $\mathrm{Fe}$ & $\mathrm{Ni}$ & $\mathrm{Cu}$ & $\mathrm{Zn}$ & As & Ag & Sn & Sb & Pt & $\mathbf{P b}$ & $\begin{array}{l}\text { Literature / } \\
\text { figure no. }\end{array}$ \\
\hline 1 & $\begin{array}{l}\text { Electrum pear shape pendant. } \\
\text { The chemical solder by the } \\
\text { filigree wires in form as a } \\
\text { sediment of red coulor. } \\
\text { The titanium content was } \\
\text { detected Ti }=0,13 \text {. } \\
\text { The results of analysis other } \\
\text { parts, see Table } 1: 34 \text {. }\end{array}$ & $\begin{array}{c}544 \\
(2798) \\
\text { stadium IIIA/IIIB }\end{array}$ & 16224,01 & 42,59 & 7,74 & 3,34 & 0 & 0,01 & 2,55 & 0,08 & 6,64 & 0,27 & 0,69 & 35,93 & 0 & 0 & 0 & 0,04 & Fig. 1:8 \\
\hline
\end{tabular}

\begin{tabular}{|c|c|c|c|c|c|c|c|c|c|c|c|c|c|c|c|c|c|c|c|c|c|c|}
\hline No. & $\begin{array}{l}\text { Description of the find/the } \\
\text { analyzed part of } \\
\text { find/Additional comments }\end{array}$ & $\begin{array}{c}\text { Grave no./ } \\
\text { inventory no./ } \\
\text { chronology }\end{array}$ & $\begin{array}{l}\text { Sample } \\
\text { no. }\end{array}$ & $\mathrm{Cu}$ & Mg & Al & $\mathbf{S i}$ & $\mathrm{Ti}$ & $\mathrm{Cr}$ & Mn & $\mathrm{Fe}$ & $\mathrm{Ni}$ & $\mathrm{Zn}$ & As & Ag & Sn & Sb & Pb & $\mathbf{P}$ & $\mathrm{s}$ & Au & $\begin{array}{l}\text { Literature / } \\
\text { figure no. }\end{array}$ \\
\hline 2 & $\begin{array}{l}\text { Silver crossbow brooch with } \\
\text { closed catchplate, decorated } \\
\text { silver gilded foil. } \\
\text { Type close to A.VI.170. } \\
\text { The tin-lead solder under the } \\
\text { foil from spring arm. } \\
\text { The results of analysis other } \\
\text { parts, see Table } 1: 12 ; 2: 31 .\end{array}$ & $\begin{array}{l}275 \\
(1247) \\
\text { stadium } \mathrm{V}\end{array}$ & 15552 & 6,31 & 0,06 & 1,97 & 0 & 0 & 0 & 0 & 0,56 & 0 & 0,72 & 0 & 0,17 & 83,03 & 0 & 7,18 & 0 & 0 & 0 & $\begin{array}{c}\text { Natuniewicz- } \\
\text { Sekula, } \\
\text { Okulicz- } \\
\text { Kozaryn 2011, } \\
\text { 80, pl. } \\
\text { CXVI:3. } \\
\text { Fig. 2:2, 4:6 } \\
\end{array}$ \\
\hline 3 & 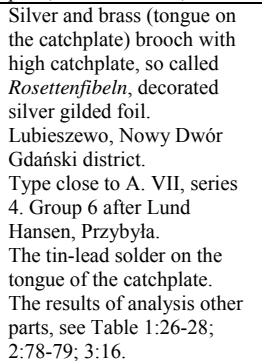 & $\begin{array}{l}10 \\
\text { (collections of } \\
\text { the Musueum of } \\
\text { Archaeology and } \\
\text { History in } \\
\text { Elblag, without } \\
\text { inventory no.) } \\
\text { phase Clb to the } \\
\text { beginning C2 }\end{array}$ & 15590,01 & 7,11 & 0 & 0,21 & 1,58 & 0 & 0 & 0 & 0,33 & 0 & 0,09 & 0,15 & 0 & 80,16 & 0 & 9,12 & 1,25 & 0 & 0 & $\begin{array}{l}\text { Jonakowski } \\
2001,187 \text {, fig. } \\
\text { 2:7 }\end{array}$ \\
\hline
\end{tabular}

